\title{
Milk protein analysis
}

\section{B. Ribadeau-Dumas ${ }^{1}$ and R. Grappin ${ }^{2}$}

1 INRA, station de recherches laitières, C.R.J., 78350 Jouy-en-Josas,

2 INRA, station de recherches de technologie et analyses laitières, B.P. 94, 39800 Poligny, France

(received 7 October 1988, accepted 27 April 1989)

Summary - After a short description of bovine milk proteins, the various methods of current or potential use for detecting and determining them in dairy products are reviewed. This includes, first, the determination of total protein from nitrogen analysis, dye-binding capacity, infra-red spectrometry and amino acid analysis. The methods that allow determination of some milk protein fractions of interest (whole casein, whey proteins, $\beta$-lactoglobulin) are then given. They include the Aschaffenburg-Rowland procedure, dye-binding and infra-red methodologies. A description of the various methods (electrophoresis, column chromatography, immunochemical or enzymatic tests), that can be used for detecting and individually quantitating the various caseins and whey proteins is presented. Finally, some applications of various analytical procedures to the analysis of different classes of dairy products are given.

analytical techniques - milk products - proteins - peptides - amino acids

Résumé - Analyse des protéines du lait - Une revue. Après une brève description des protéines du lait de vache, les différentes méthodes utilisées ou pouvant être utilisées pour mettre en évidence et doser ces protéines dans les produits laitiers sont passées en revue. Dans une première partie sont décrites les techniques permettant le dosage des protéines totales par dosage d'azote, fixation de colorants, spectrométrie infrarouge, puis celles qui permettent le dosage de certaines fractions protéiques (caséine entière, protéines du lactosérum, $\beta$-lactoglobuline) : méthode d'Aschaffenburg-Rowland et méthodes qui utilisent la fixation de colorants ou la spectrométrie infrarouge. Sont examinées ensuite les diverses techniques permettant la détection et le dosage individuel des principales protéines du lait, par électrophorèse, chromatographie sur colonne, par des tests immunochimiques ou enzymatiques.

Pour terminer, sont donnés des exemples d'applications de plusieurs méthodes à l'analyse de produits laitiers divers.

techniques analytiques — produits laitiers — protéines — peptides - acides aminés 


\section{INTRODUCTION}

This review concerns all types of analyses dealing with proteins in milk, dairy and a few non-dairy products. Only the methods that are in current use, or those which have been recently published and might become of general use, will be considered. For all of them, the reader will be supplied with basic principles, schematic descriptions, references and critical evaluations.

Compared to other food products, milk is a fairly simple fluid. It has been thoroughly studied from the beginning of the 19 th century. Its composition and the main characteristics of its various constituents are now well known. In particular, the amino acid sequence of its 7 main protein components has been elucidated. There is currently no other food product whose proteins are so well characterized. This makes their analysis straightforward in raw milk. However, as soon as technological treatments have been applied, any quantitative measurement, except nitrogen determination, becomes far more difficult. In particular, protein denaturation, which is not a onestep phenomenon, leads, for a given protein, to products which may differ according to the treatment, often with an ultimate transformation into insoluble aggregates. Furthermore, a number of chemical reactions may occur during the processing of milk, dairy products and non-dairy products which lead to covalent modifications of proteins. In a number of food products, milk proteins have been intentionally fragmented into peptides and amino acids by proteinases and peptidases. Of course, it is not possible to determine from which protein free amino acids originated. Theoretically, the origin of any peptide with more than 5 amino acid residues, provided it can be isolated, can usually be established if it is derived from any milk protein. However, even the rough characterization of a milk protein hydrolyzate is a difficult and long task which can only at the moment be performed in a few research laboratories.

As knowledge of the main characteristics of the various milk proteins is essential for those who wish to obtain reliable analytical data concerning them, we will first describe them, as well as their fate, in the various dairy products. Then, the procedures allowing their determination as a whole and individually in these products will be reviewed, as well as those used for detecting and determining them in non-dairy products. Finally, we will describe the techniques available for assessing their quality in dairy products. However, the methods used to assess milk protein digestibility in vitro or in vivo will not be described as the authors are not specialists in this area.

\section{Characteristics of milk proteins}

The white appearance of raw milk is due to light scattered by two types of particles in suspension in lactoserum (whey), fat globules and casein micelles.

Fat globules are large (diameter 2 to $12 \mu \mathrm{m}$, average ca. $4 \mu \mathrm{m}$ ), spherical triglyceride particles, surrounded by a unit membrane composed mainly of phospholipids and proteins such as xanthine oxidase and butyrophilin. High pressure homogenization, as used for liquid milk manufacture or infra-red (IR) determination of the main milk components, disrupts these globules into much smaller particles (average diameter : $1 \mu \mathrm{m}$ ). Skim milk proteins replace the destroyed natural membrane on these globules (Keenan et al., 1983). 
The white appearance of skim milk results from light scattering by much smaller particles (diameter from 20 to 600 $\mathrm{nm}$; average ca. $100 \mathrm{~nm}$ ), i.e. the casein micelles. These consist mainly of water (4 g/g whole casein), proteins ("whole casein") and minerals (60 $\mathrm{mg} / \mathrm{g}$ whole casein), mainly phosphate and calcium (Schmidt, 1982). Milk contains ca. $33 \mathrm{~g} / \mathrm{l}$ proteins (27 $\mathrm{g}$ whole casein, $6 \mathrm{~g}$ whey proteins). In addition, some non-protein nitrogenous (NPN) substances (ca.1.5 $\mathrm{g} / \mathrm{l})$ occur in milk : urea, creatinine, ammonia, peptides, nucleotides, vitamins etc.) (Table I).

Lowering the $\mathrm{pH}$ of milk (ca. 6.7 for fresh milk) to 4.6 precipitates whole casein, leaving, in solution, the other milk proteins, the NPN and the minerals which were associated with casein micelles. Treatment of milk with rennet (a calf abomasum extract containing two milk clotting proteinases, chymosin and pepsin) is the first step in cheese manufacture; it leads to milk clotting. The clot (curd), after draining of whey, is constituted of almost intact whole casein to which the minerals of the casein micelles are still bound. One of the four protein components of whole casein, $\mathrm{K}$ casein (ca. $12 \%$ whole casein) has been split into two parts by rennet. The larger fragment (para-k-casein, $2 / 3$ of the molecule) remains in the clot, while the smaller one (casein macropeptide, CMP) is present in the whey, together with NPN and the whey proteins. Thus, acid and rennet wheys differ only in that the latter contains CMP and has a lower mineral content (Dalgleish, 1982).

\section{The caseins}

Casein micelles contain only 4 protein species, $\alpha_{\mathrm{s} 1^{-}}, \alpha_{\mathrm{s} 2^{-}}, \beta-$ and $\kappa$-caseins,

Table I. Average protein composition of cow milk. Composition protéique moyenne du lait de vache.

$\begin{array}{lr}\alpha_{\mathrm{s} 1} \text {-Casein } & 10.0 \\ \alpha_{\mathrm{s} 2} \text {-Casein } & 2.6 \\ \beta \text {-Casein } & 9.3 \\ \kappa \text {-Casein } & 3.3 \\ \gamma \text {-Caseins } & 0.8 \\ \text { Proteose-peptones } & 0.8 \\ \alpha \text {-Lactalbumin } & 1.2 \\ \beta \text {-Lactoglobulin } & 3.2 \\ \text { Serum albumin } & 0.4 \\ \text { Immunoglobulins } & 0.8 \\ \text { Lactoferrin } & 0.1 \\ \text { Transferrin } & 0.1 \\ \text { MFGM } & 0.4 \\ \text { Milk } & 33.0\end{array}$

From: Walstra, P. \& Jenness, R. (1984) Dairy Chemistry and Physics, New York, Wiley-Interscience. Composition typical of milks from Lowland breeds. MFGM, proteins of milk fat globule membranes. D'après Walstra P. \& Jenness R. Dairy Chemistry and Physics, New York, Wiley-Interscience, 1984. Composition typique du lait de troupeaux Lowland. MFGM, protéines de la membrane des globules gras. 
bound together by amorphous calcium phosphate (the so-called colloidal phosphate). A small proportion of $\beta$ - and $\alpha_{s 2}$-Cns occurs, even in fresh milk, as fragments arising from partial digestion by an endogenous milk proteinase, plasmin. Some of these fragments are found in acid casein and in rennet curd. This is the case for $\gamma 1-, \gamma 2$ - and $\beta 3-C n s$, derived from $\beta-\mathrm{Cn}$. Others, some of the so-called proteose-peptones, also derived from $\beta-\mathrm{Cn}$, and the fragments of $\alpha_{\mathrm{s}^{2}} \mathrm{Cn}$, are found in the whey (Swaisgood, 1982).

A small proportion of caseins are not in the micellar state ("soluble casein"). The proportion of soluble casein increases when the temperature is lowered, and can reach up to $20 \%$ of whole casein when milk is kept at $4{ }^{\circ} \mathrm{C}$ for a day or more. This phenomenon is reversible : heating milk reduces the proportion of soluble casein. Furthermore, addition of $\mathrm{CaCl}_{2}$ to fresh milk drives almost all soluble casein into micelles. Subsequently, high speed centrifugation (ca. $90000 \mathrm{~g}, 1 \mathrm{~h}$ ) allows complete sedimentation of casein micelles. $\beta-C n$ represents a large proportion of the soluble casein (Reimerdes, 1982).

The 4 caseins display common features that are quite unusual. They are hydrophobic, phosphorylated proteins, always occurring as large, polydisperse aggregates in aqueous solution at ambient temperature and neutral $\mathrm{pH}$. Each displays a loose, highly hydrated tertiary structure. They are highly susceptible to all proteinases and exopeptidases. Severe heat treatments (sterilization) do not affect them significantly. Antibodies against native caseins also recognize these proteins after heat treatments.

Caseins, proteose-peptones and CMP are negatively charged molecules above $\mathrm{pH} \mathrm{7,} \mathrm{while} \mathrm{para-} \mathrm{k}-\mathrm{Cn}$ is positively charged. For this reason, electrophoresis and ion exchange fractionation of caseins are usually performed around $\mathrm{pH} 8.5$. The isoelectric pHs of caseins lie between 4.5 and 5.5. Those of para- $\mathrm{k}-\mathrm{Cn}$ and $\gamma$-Cns are higher, while those of proteosepeptones and CMP are lower (Dalgleish, 1982; Swaisgood, 1982).

Since caseins associate with each other in solution, mainly through hydrophobic interactions, separation of the isolated molecules by electropheresis or ion exchange chromatography requires the addition of an agent, usually urea, able to disrupt these interactions. Furthermore, as $\alpha_{\mathrm{s}^{-}}$and $\kappa-\mathrm{Cns}$ each contain 2 cysteine residues, complete dissociation necessitates the addition of a reducing agent such as 2-mercaptoethanol to cleave any S-S bridge (Swaisgood, 1982).

The primary structures of the 4 bovine caseins are known (Swaisgood, 1982). All are single chain proteins. $\alpha_{s 1}-C n$ has 199 amino acid residues, 8 phosphate groups linked to serine residues (a small fraction of $\alpha_{s 1}-\mathrm{Cn}$, the so-called $\alpha_{\mathrm{s} 0}-\mathrm{Cn}$, has 9 phosphate groups). $\beta-\mathrm{C} n, 209$ residues long, has 5 phosphate groups. Together, these 2 caseins, whose proportions in milk are approximatively similar, constitute about $70 \%$ of whole casein. $\alpha_{s 2^{-}}$and $\kappa$-Cns each represent ca. $13 \%$ of whole casein. The former, 207 residues long, occurs in milk as 4 molecular species at least, which differ only in their number of phosphate groups (10 to 13). The 4 species were once called $\alpha_{\mathrm{s}^{-}}, \alpha_{\mathrm{s} 3^{-}}, \alpha_{\mathrm{s} 4^{-}}$ and $\alpha_{\mathrm{s} 6}-\mathrm{Cns}, \alpha_{\mathrm{s} 5}-\mathrm{Cn}$ being a dimer $\alpha_{\mathrm{s} 3^{-}}$ $\alpha_{\mathrm{s} 4}$ (Eigel et al., 1984).

$\kappa$-casein, 169 residues long, is cleaved by chymosin and pepsin between residues 105 and 106. Fragment $1-105$ is para-k-casein, a highly hydrophobic, positively charged molecule at neutral $\mathrm{pH}$. The fragment $105-169$ is CMP, which is highly hydrophilic, carries one (or two) 
phosphate groups and various numbers of serine- and threonine-linked oligosaccharide side-chains of various lengths, composed of $\mathrm{N}$-acetylgalactosamine, galactose and $\mathrm{N}$-acetylneuraminic acid (NANA). Thus, $\kappa-\mathrm{Cn}$ consists of a population of closely related molecules which can be partially resolved into more than 7 components by electrophoresis or ion exchange chromatography, since their charges at alkaline $\mathrm{pH}$ differ according to their NANA and phosphate content (Swaisgood, 1982).

The solubility of caseins displays some characteristic features. It is well known and understood that any protein has a solubility minimum at its isoelectric $\mathrm{pH}$. The caseins are almost completely insoluble at $\mathrm{pH} 4.6$, e.g., commercial "acid casein" is insoluble. However, it can be brought into solution by bringing a dispersion of casein in water to $\mathrm{a} \mathrm{pH}$ of 7 or above by adding an alkali until it is dissolved. Commercial sodium and calcium caseinates are prepared in this way by using sodium and calcium hydroxides, respectively. However, $\mathrm{Ca}$ ions (neutralization of acid caseinate with calcium hydroxide or addition of $\mathrm{CaCl}_{2}$ to sodium caseinate at constant, neutral $\mathrm{pH}$ ) induce the formation of casein micelles. Among the 4 caseins, 3 of them, $\alpha_{s 1}, \alpha_{s 2}$ and $\beta$, are very insoluble in the presence of millimolar concentrations of $\mathrm{Ca}^{2+}$, while this ion does not affect the solubility of $\kappa-\mathrm{Cn}$ (this is also the case for $\beta-\mathrm{Cn}$ at low temperatures). When $\kappa-C n$ is added to neutral solutions of $\alpha_{\mathrm{s} 1^{-}}, \alpha_{\mathrm{s} 2^{-}}$or $\beta$-Cns, or a mixture of them, it stabilizes these caseins against calcium precipitation. Lowering the $\mathrm{pH}$ of such mixtures, as well as that of milk, progressively removes calcium, and calcium-free caseins precipitate at their isoelectric $\mathrm{pH}$. The stabilization of caseins by $\kappa-\mathrm{Cn}$ towards calcium precipitation is abolished when rennet releases CMP.
Common genetic variants of caseins are $\alpha_{s 1} B$ and $C, \alpha_{s 2} A, \beta A^{1}, A^{2}$ and $C, \kappa$ $A$ and $B$. Monomeric caseins have a similar $M_{\mathrm{r}}$, ranging from ca. 20000 to 25000 (Swaisgood, 1982).

\section{Whey proteins}

Unlike the caseins, the whey proteins are classic globular proteins with a tight tertiary structure, occurring in milk as monomers or oligomers. Two of them are dominant, $\beta$-lactoglobulin $(\beta-\mathrm{Lg})$ and $\alpha$-lactalbumin ( $\alpha$-La) which represent ca. 50 and $12 \%$ of total whey proteins, respectively. Several other proteins occur in milk : serum albumin (BSA), immunoglobulins (Igs), lactoferrin (LF), and enzymes such as lactoperoxidase (LP), xanthine oxidase, etc. (Jenness, 1982; Kitchen, 1985). Except for BSA and xanthine oxidase, all milk proteins mentioned above have been prepared at least on a pilot scale. More details on some biologically active whey proteins (LF, Igs and enzymes) will be given in a later section. Determination of the activity of several of them is especially useful, in particular, for assessing the severity of heat treatments.

$\beta$ - $\mathrm{Lg}$ occurs in milk as a dimer $\left(M_{r}\right.$ $36000)$ of two identical subunits. The primary and tertiary structures of the monomer are known (Papiz et al., 1986). According to the conditions of $\mathrm{pH}$, ionic strength etc., monomeric, dimeric, tetrameric or octameric $\beta-\mathrm{Lg}$ can be found. This protein has a free $\mathrm{SH}$ group which is involved in interactions with other proteins, such as $\kappa$ - and $\alpha_{\mathrm{s} 2}$-Cns, through the formation of disulfide bridges on heating. In its native state it possesses two such bridges. Irreversible denaturation of $\beta-\mathrm{Lg}$ in milk may occur during drastic heat treatments. Two common 
genetic variants of $\beta-\mathrm{Lg}(A$ and $B$ ) occur with similar frequencies; therefore, both of them are found in bulk milk. They can be easily separated by electrophoresis or column ion exchange at alkaline $\mathrm{pH}$. Their isoelectric pHs are between 5.3 and 5.5 . $\beta-\mathrm{Lg}$ is very resistant to proteolytic enzymes (Swaisgood, 1982; Papiz et al., 1986).

$\alpha$-La in milk exists in the monomeric state $\left(M_{r} 14000\right)$. It is a metallo protein to which a $\mathrm{Ca}$ ion is strongly bound, and it contains 2 disulfide bridges. Its primary and tertiary structures are known (Stuart et al., 1986). Around $\mathrm{pH} 3.5$, the conformation of the protein changes and the $\mathrm{Ca}$ ion is released. The "acid form", A, has a slightly more open structure than those of the native form $(\mathrm{N})$ and the apo- $\alpha$-La (Ca-free, neutral $\mathrm{pH}$ ). Conversion, from one of these forms to the other, is reversible, while denaturation (heat or $\mathrm{Gu} . \mathrm{HCl}$ treatments) results in an irreversibly expanded structure. It is irreversibly denatured in milk by severe heat treatments. Its isoelectric $\mathrm{pH}$ is $\mathrm{ca}$. 4.3 (Swaisgood, 1982; Pfeil, 1987).

Both whey proteins lose their native antigenic determinants when they are irreversibly denatured. Thus, their reaction with antibodies raised against the native proteins can be used to assess the extent of their denaturation.

Whey proteins as a whole $(4-7 \mathrm{~g} / \mathrm{l})$ are the most interesting components of whey, a by-product of cheese and casein manufacture, which mainly contains lactose (44 to $53 \mathrm{~g} / \mathrm{l})$. Whey also contains minerals (5 to $8 \mathrm{~g}$ ash $/$, according to the method of manufacture) and ca. $0.3 \mathrm{~g} / \mathrm{l}$ fat, mainly phospholipids. One of the oldest methods used to recover whey proteins involves heat denaturation at acid $\mathrm{pH}$. The resulting so-called "lactalbumin" is insoluble and lacks the functional properties of the native proteins.
Another commercially available protein product derived from milk is "coprecipitate". Its manufacture involves heating of milk to ca. $90^{\circ} \mathrm{C}$ and precipitation of caseins plus whey proteins at $65^{\circ} \mathrm{C}$, by acidification to $\mathrm{pH} 4.6-5.6$, or by addition of soluble calcium salts.

An increasing proportion of whey is treated each year by ultrafiltration for the manufacture of whey protein concentrates (WPC) which have high protein contents (30-70\%).

Finally, modified whey powders are available, which have low contents in lactose or minerals or both. These are obtained by lactose crystallization and/or whey demineralization by electrodialysis or ion-exchange (Muller, 1982; Marshall, 1982).

Several laboratories and firms are attempting to separate $\beta$ - $\mathrm{Lg}$ from $\alpha$-La on an industrial scale. One can see two reasons for this operation : first, it would allow exploitation of their different functional properties in food manufacture. Second, it is considered that $\beta-\mathrm{Lg}$ is detrimental to human neonates fed cow milk, or "humanized milk" in which the ratio whole casein-whey proteins is lowered to attain the value observed in human milk. This assumption is based on the allergenicity of $\beta-\mathrm{Lg}$, which seems somewhat higher than that of the other bovine milk proteins. The absence of $\beta-\mathrm{Lg}$ from human milk is also proposed as a reason for eliminating this protein from infant formulas.

A method was published by Pearce (1983b) which, in our opinion, is quite promising. By moderate heat treatment ( $65^{\circ} \mathrm{C}$ for less than $30 \mathrm{~min}$ ) of Cheddar cheese whey retentate brought to $\mathrm{pH} 4.1$ 4.3 , all whey proteins precipitated except $\beta$-Lg. This separation has been quite clear-cut in our experience. An improved modification of this technique has been 
developed by Pierre \& Fauquant (1986). However, nobody knows whether the resulting precipitate, which besides $\alpha$-La, contains a fairly large amount of BSA, IgGs and LF, is less detrimental than $\beta-L g$ to babies allergic to cow milk.

\section{Characteristics of some biologically active proteins}

All milk proteins are likely to have a biological function in the cow or/and in the calf. They all supply the latter with the amino acids it needs. This is especially the case for caseins which are quite accessible to the gastrointestinal proteolytic enzymes. In addition, the micellar system provides the calf with large amounts of calcium and phosphate; clotting of milk in the stomach regulates intestinal transit. $\alpha$-La is part of the enzyme lactose synthetase which catalyzes the last step in the biosynthesis of lactose (Kuhn, 1983). $\beta$ - Lg has recently been found to be a retinol-binding protein (Papiz et al., 1986). LF, IgGs and LP are involved in the protection of the mammary gland and of the calf's gut against pathogenic microorganisms. We do not know whether the many enzymes that are present in milk have any particular function. Most of them occur and have definite functions in the body fluids of the cow and/or they may simply occur through "leakages" from blood. Indeed, milk plasminogen $(\mathrm{Pg})$, the precursor of plasmin, an active proteinase, has been shown to originate from blood (Eigel et al., 1979), in which it has an important function (lysis of fibrin clots).

We will focus here on those biologically active milk proteins whose activity can be exploited in dairy technology, or must be avoided : LP, IgGs, LF, plasmin, catalase and alkaline phosphatase (AP).

\section{Lactoperoxidase}

This is the most abundant enzyme in milk (ca. $30 \mathrm{mg} / \mathrm{l}$ ). It is virtually completely inactivated by pasteurization of milk at $78^{\circ} \mathrm{C}$ for 15 s (Griffiths, 1986). LP (EC 1.11.1.7) catalyzes the oxidation by hydrogen peroxide of a number of unsaturated organic compounds (e.g.,odianisidine, pyrogallol, guaiacol) and some halides or pseudo-halides $(\mathrm{Br}, \mathrm{I}$, $\mathrm{SCN}^{-}$). The oxidation of $\mathrm{SCN}^{-}$and $\mathrm{I}^{-}$is of special interest, as well as that of some organic compounds that can be used for colorimetric determination of LP in processed milk to assess pasteurization efficiency. The preparation of LP from milk or whey (e.g., Prieels \& Peiffer, 1985; Mailliart \& Ribadeau-Dumas, 1987) is fairly easy because of its high isoelectric $\mathrm{pH}$ (ca. 9.5) and molecular weight (ca. 78 $\mathrm{kDa}$ ). It is now commercially available from a few dairy firms. Carbohydrates and a heme group are attached to the protein molecule. The latter is essential for activity and gives solutions of the enzyme a greenish color, with an absorbance maximum at $412 \mathrm{~nm}$. For the purest preparations of LP, the ratio $E 412 \mathrm{~nm} / \mathrm{E}$ $280 \mathrm{~nm}$ reaches a value of $c a$. 1.0. On ion exchange chromatography, LP appears to be heterogeneous, possibly due to different degrees of glycosylation or partial proteolysis.

LP catalyses the iodination of free or protein-bound tyrosine, according to the reaction :

$$
\mathrm{I}^{-}+\mathrm{H}_{2} \mathrm{O}_{2}+\mathrm{HO}-\mathrm{CH}_{2}-\mathrm{CH}-\underset{\mathrm{HN}}{\mathrm{CO}}
$$

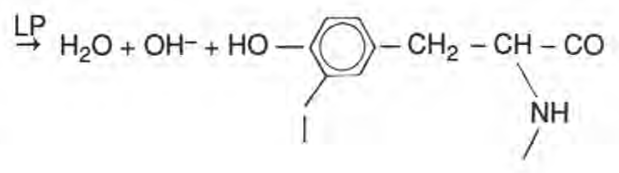


This reaction is widely used for the radiolabelling of proteins, e.g., with 1251 . The specific activity of LP for iodination is more than 100-fold higher than that of horseradish peroxidase (HP) (Pruitt \& Tenovuo, 1985).

LP, as well as HP and AP, is used in enzyme-linked immunosorbent assays (ELISA). The ELISA techniques can be employed to determine any antigen $\mathrm{Ag}$ (e.g., protein, microorganism, etc.) in complex media. In the procedure using inhibition of antibody binding, antibodies (Ab1) are raised against $\mathrm{Ag}$ in, say, rabbits. Other antibodies (Ab2) are raised against $A b 1$ in another animal species, purified and covalent complexes LP-Ab2 prepared. A known amount of pure $\mathrm{Ag}$ is insolubilized and fixed in an plastic well and a suboptimal amount of $\mathrm{Ag} 1$ is added together with an aliquot of the medium in which $\mathrm{Ag}$ is present at a concentration to be determined. This soluble Ag partially inhibits the binding of $\mathrm{Ab} 1$ to the insoluble Ag. After washing, LP-Ab2 is added in excess and the excess is washed-out. The amount of fixed LP-Ab2, measured from the LP-activity, is inversely proportional to the amount of added soluble $\mathrm{Ag}$ to be determined. The extreme sensitivity of ELISA techniques is due to the fact that several Ab1 molecules bind to one $\mathrm{Ag}$ molecule. Similarly, several molecules of LP-Ab2 bind to each molecule of Ab1. Therefore, a large number of LP molecules corresponds to a single Ag molecule.

It seems that LP, which is present in most mucosal secretions (milk, saliva, cervical mucus), has a biological function both in the mammary gland and in the digestive tract of the calf. In vitro and in milk, it constitutes part of a bactericidal system (LP-system) that involves the following reaction :

$$
\mathrm{SCN}^{-}+\mathrm{H}_{2} \mathrm{O}_{2} \stackrel{\text { LP }}{\longrightarrow} \mathrm{OSCN}^{-}+\mathrm{H}_{2} \mathrm{O}
$$

This system is active against a number of Gram+ and Gram- bacterial strains.

The hypothiocyanite ion, OSCN-, or higher oxiacid derivatives, is responsible for the antibacterial effect which is believed to be due to oxidation of $\mathrm{SH}$ groups, $\mathrm{NADH}$ and NADPH, that are essential for bacteria. The $\mathrm{SCN}^{-}$level in milk is significant for cows fed on grass or hay. However, there is no source of $\mathrm{H}_{2} \mathrm{O}_{2}$ in normal fresh milk. Xanthine oxidase, an enzyme of the fat globule membrane, is able to liberate $\mathrm{H}_{2} \mathrm{O}_{2}$, but there is not enough substrate (such as xanthine, aldehydes) in milk for this enzyme. The LP-system may be activated in the mammary gland in case of mastitis, $\mathrm{H}_{2} \mathrm{O}_{2}$ being produced by bacteria or phagocyting leucocytes. Similar activation could occur in the gut of the calf (Pruitt \& Tenovuo, 1985).

Activation of the LP-system by adding 10-12 ppm thiocyanate and 8-10 ppm $\mathrm{H}_{2} \mathrm{O}_{2}$, has been used as a means of protecting milk in tropical countries from early spoilage (Pruitt \& Tenovuo, 1985). The same system can be used in nondairy products (or milk products in which LP has been destroyed by heat treatments), provided the 3 components of the system ( $\left.\mathrm{LP} / \mathrm{SCN}-/ \mathrm{H}_{2} \mathrm{O}_{2}\right)$ are added. Data from one of the LP-producing firms (Oleofina, Brussels) seem to show that supplementation of the diet with both LP and LF can prevent microbial diarrhoea in calves.

\section{Immunoglobulins}

In the adult cow, lymphocytes- $B$ are activated by foreign $\mathrm{Ag}$ macromolecules (e.g., from bacteria), and each proliferates and differentiates to a plasmocyte that secretes into the blood IgGs (or IgMs), specific for the antigenic determinant (a 
part of the $\mathrm{Ag}$ ) which has caused the initial activation. IgGs are large molecules made up of two sets of two identical peptide chains, light $(L)$ and heavy $(H)$. The light chains $\left(M_{r} 22500\right)$ can be of two types ( $\kappa$ or $\lambda$ ). Similarly, in the cow, there are two types of heavy chains, $\gamma 1$ and $\gamma 2$, giving the sub-classes $\operatorname{lgG} 1$ and $\lg G 2$. Some carbohydrates are bound to the $\mathrm{H}$ chains. The four chains are linked together by several disulfide bridges. It is not possible in this review to give a detailed description of the mechanism of action of IgGs. Let us just say that, when the blood stream has previously encountered a bacterium, for example, the organism possesses a number of lymphocytes $B$ able to produce a myriad of plasmocyte clones, each is able to secrete one type of $\lg$ specific for one of the many determinants of the same bacterium. These $\mathrm{lgGs}$ each bind to the corresponding determinant. IgG fixation induces the activation of "complement", a dozen serum proteinases or proteins which activate each other to ultimately perforate the bacterial membrane and thus destroy the microorganism.

This means that a large population of similar, but not identical, IgGs circulate in the blood stream. The calf, which is born devoid of any circulating lgGs, must receive them from colostrum, which is highly charged with lgGs, and the milk of its mother. The cow mammary gland selectively transfers lgG1 from blood serum to colostrum (ca. $60 \mathrm{~g} / \mathrm{l} \mathrm{lgs}, 80 \%$ as $\lg \mathrm{G} 1$ ). The other lgs found in colostrum and milk are lgMs (whose function is similar to that of $\operatorname{lgGs}$ ) and secretory $\lg A s$ (slgAs) that are specific to external secretions (milk, saliva, gastrointestinal mucus, etc.). The latter have a local action against microorganisms. In the gut, they aggregate those which have induced their production (as for $\mathrm{IgGs}$ ), thus preventing their attachment to the intestinal epithelium. In mature cow milk, the total Ig content is much lower ( $\mathrm{Ca} 0.8$ $\mathrm{g} / \mathrm{C}$ ) than in colostrum and the proportion of $\lg A$ s is higher : $70 \% \lg \mathrm{G}_{1}, 17 \% \operatorname{sig} A$ (Butler, 1974). Preparation of lgs, from colostrum or milk, is now feasible on a pilot scale (e.g., Peyrouset, 1982). The resulting products contain a huge variety of molecular species directed against a number of unknown microorganisms, unless the cow has been vaccinated against the known ones. In that case, part of the $\mathrm{lgGs}$ found in colostrum and milk will be active against the latter after they have passed into the calf's blood serum. Igs prepared from milk or colostrum whey are mainly used in veterinary medicine for supplementing calf diet.

\section{Lactoferrin}

LF consists of a single peptide chain of $M_{\mathrm{r}}$ 80000 . The primary structure of human milk LF is known. The protein has 703 amino acid residues and 16 disulfide bridges. It bears 2 carbohydrate chains. The molecule is formed of 2 symmetrical homologous parts, each carrying a $\mathrm{Fe}^{3+}$ binding site (Metz-Boutigue et al., 1984). For each ferric ion bound to such a site, one bicarbonate anion is concomitantly bound, and ca. 3 protons are released. Iron and carbonate alone cannot bind tightly. Bovine colostrum and milk contain approximately 6 and 0.2 g/l LF, respectively, which is found exclusively in whey. Although the degree of iron saturation of bovine LF in milk is a matter of controversy, LF preparations show a degree of saturation of ca. $20 \%$. Bovine $\mathrm{LF}$ is commercially available. Its high isoelectric $\mathrm{pH}$ (ca. 8) makes its preparation from whey by ion exchange fairly easy (e.g., Peyrouset, 1982; Prieels \& Peiffer, 1985; Monsan et al., 1985; Mailliart \& Ribadeau-Dumas, 1987). 
Conventional pasteurization does not denature it extensively.

Like LP and IgAs, LF occurs in most exocrine secretions (bronchial mucus, saliva, tears, gastric juice, duodenal mucus, etc.). It is also present in neutrophil granulocytes.

Iron saturation and depletion can be easily performed without altering the protein molecule. The saturated form is pink, with a broad absorbance maximum at $460 \mathrm{~nm}$. When the $\mathrm{pH}$ is lowered, LF begins to lose iron around $\mathrm{pH} 4.5$. At $\mathrm{pH}$ 4.4 , the iron saturation level is still $75 \%$.

Although many investigations have been concerned with the biological role of LF, the situation is still not clear. Two main putative functions have been assigned to this milk protein. Together with IgAs, LP and lysozyme, it could act as an antibacterial agent in exocrine secretions. Indeed, it has been known for a long time that unsaturated LF prevents, in vitro, the growth of a number of bacterial strains by chelating the iron they need for growth. This bacteriostatic effect is enhanced by Igs. It may protect the mammary gland; in this organ the LF concentration increases markedly during mastitis and involution. It may also protect the digestive tract of the calf against pathogenic microorganisms. However, this has not been clearly demonstrated. As mentioned above, a producer firm claims a beneficial action of $\mathrm{LF}+\mathrm{LP}$ in preventing-diarrhoea in calves.

Also, LF could play a role similar to that of blood serum transferrin, a very similar protein, by making iron more available for absorption in the gut. Indeed, receptors for LF have been found in human and monkey brush border membrane (Huebers \& Finch, 1987).

\section{Catalase, Alkaline Phosphatase, Plasmin}

These enzymes, which are quite different, have been placed together here because determination of their activities in milk is used or could be used as quality criteria.

High levels of catalase (and $\mathrm{N}$-acetyl glucosaminidase) in milk usually result from mastitis. The absence of AP (or LP; see above) in pasteurized milk indicates that the heat treatment has been high enough to destroy pathogenic germs. Finally, a high level of plasmin activity in raw milk may be detrimental for further processing (cheese manufacture, UHT treatment).

\section{Catalase (EC 1.11.1.6)}

This enzyme is found in both skim milk and cream, and appears to be associated with membrane material in both of these fractions. Its level in milk is correlated with the somatic cell count and thus, the measure of its activity can be used to detect mastitis (Kitchen, 1985). The enzyme has been crystallized from buttermilk (Ito \& Akusawa, 1983). It is found in nearly all aerobic cells, and in vivo, is partially responsible for protecting cells against the toxic effects of $\mathrm{H}_{2} \mathrm{O}_{2}$. Mammalian catalases consist of 4 identical subunits of $M_{r} 60000$, each bearing a heme group (Fe IIIprotoporphyrin $(X)$. The known amino acid sequences of catalase from bovine liver and erythrocytes are identical (Quan et al., 1986). Catalase from milk is likely to be the same molecule. The enzyme catalyses the reaction :

$$
2 \mathrm{H}_{2} \mathrm{O}_{2} \longrightarrow 2 \mathrm{H}_{2} \mathrm{O}+\mathrm{O}_{2}
$$


Its optimum $\mathrm{pH}$ and temperature are 8.0 and $20^{\circ} \mathrm{C}$, respectively. It is one of the more heat-labile enzymes occurring in milk, with most of its activity being destroyed at $72{ }^{\circ} \mathrm{C}$ for $15 \mathrm{~s}$ (Griffiths, 1986).

High level of $N$-acetyl- $\beta$-D-glucosaminidase (EC 3.2.1.30) in milk is also found during mastitis (Kitchen, 1985).

\section{Alkaline Phosphatase (EC 3.1.3.1)}

Like the former, this enzyme is found mainly in membrane structures of both skim milk and cream. It has been shown that at least 3 genes code for 3 different APs : the placental, intestinal and liver/ bone/kidney (LBK) APs (Weiss et al., 1986).

Complete primary structure of 3 APs are known : that of the $E$. coli enzyme, and those of the human placental and LKB APs. All three display homologies, with $52 \%$ amino acid identity between the 2 human enzymes. Human milk AP appears to be quite similar to the liver enzyme. Both enzymes probably differ only in their carbohydrate moieties (Hamilton et al., 1979; Weiss et al., 1986). The human LBK enzyme has a single 524-residue-long chain. It contains 5 potential sites of glycosylation. According to recent data (Weiss et al., 1986), these enzymes are anchored to the luminal side of cells, either by a C-terminal hydrophobic stretch of ca. 23 amino acids, or by covalent binding to phosphatidyl inositol.

The bovine milk enzyme appears to be a dimer of two identical subunits $\left(M_{\mathrm{r}} \sim\right.$ 85000 ). Several $\mathrm{Zn}$ atoms seem to be essential for activity. The enzyme has been purified from buttermilk. It is able to hydrolyse most phosphomonoesters : AMP, glycerophosphates, free and protein-bound threonine and serine phosphate. However, it does not seem to be active in milk towards caseins, probably because of inhibition by inorganic phosphate, lactose and $\beta-\mathrm{Lg}$ (Kitchen, 1985).

The determination of AP is applied to dairy products to determine whether pasteurization has been performed properly and also to detect the possible contamination of pasteurized milk by raw milk. An almost complete loss of activity is obtained by heating milk at temperatures above $70^{\circ} \mathrm{C}$ for $15 \mathrm{~s}$ (Griffiths, 1986).

\section{Plasmin (EC 3.4.21.7)}

Bovine plasminogen $(\mathrm{Pg})$ is a single-chain blood serum protein composed of 786 amino acid residues with a number of disulfide bridges and 2 carbohydrate moieties (Schaller et al., 1985). In blood, $\mathrm{Pg}$ is involved in the lysis of fibrin clot. Blood vessel endothelium synthesizes the tissue $\mathrm{Pg}$-activator (t-PA), a serine proteinase, which is able, by splitting the single peptide bond $557-558$, to convert $\mathrm{Pg}$ into plasmin, another serine proteinase, consisting of a heavy and a light chain linked by 2 disulfide bridges (Schaller et al., 1985). A small proportion of $\mathrm{Pg}$ is transferred to milk (Eigel et al., 1979 ) in which both $\mathrm{Pg}$ and plasmin are found in a ratio of ca. 9:1. They seem to be bound to casein micelles and the milk fat globule membrane (MFGM) (Hofmann et al., 1979). $\mathrm{Pg}$ activation occurs in the mammary gland and in milk during storage, activation being faster in pasteurized than in raw milk (De Rham \& Andrews, 1986). Plasmin is the main proteinase in milk. It is known to digest mainly $\beta$ - and $\alpha_{s 2}$-Cns, as indicated earlier, and appears to have a significance in the processing technology of milk and dairy products. In some products, such as Gouda and Swiss-type 
cheese, its presence may be beneficial, while in others, such as UHT milk and some casein products, it may be deleterious (Richardson, 1983). Indeed, plasmin is fairly resistant to heat treatments (Driessen \& Van der Waals, 1978). Finally, is is useful to know that milk contains not only a PA (probably t-PA), but also plasmin inhibitors, such as $\alpha 2$ antiplasmin, and, probably, Pg-activator inhibitor which, like t-PA, is secreted by the epithelium of blood vessels.

\section{DETERMINATION OF TOTAL PROTEIN IN MILK AND DAIRY PRODUCTS}

As in many other fields, the nature and number of analyses performed to assess the composition of milk and dairy products have changed dramatically during the past 20 years. Fat, which was considered to be the most valuable component in milk since the very beginning of the dairy industry, is now being replaced by proteins which have higher nutritional and economic values. In most countries with highly developed dairy industry, protein content is now included in milk quality payment schemes and breeding programs.

Progress in milk protein research, as well as the applications of protein testing to dairy husbandry and quality control in the dairy industry, were for a long time hampered because no rapid and accurate method of analysis was available. A major breakthrough occurred with the introduction of the dye-binding methods in the 1960 's, followed by the development of the infra-red (IR) techniques which had the advantage of measuring directly all the major milk compounds : fat, protein and lactose.
This chapter will first deal with new developments concerning the determination of nitrogen, mainly by the Kjeldahl method, then the two most important indirect methods currently in use in dairy laboratories, dye-binding and IR methods, will be described. Because most of the studies in this field have been devoted to milk protein testing, relatively little information is available on their application to dairy products. Extensive reviews on the numerous methods for measurement of the protein content in milk have been published by Bosset et al. (1976), and Guillou et al. (1986).

\section{"Direct" methods (nitrogen determin- ation)}

In milk, as well as in other foodstuffs, nitrogen is the element which essentially characterizes proteins. As a consequence, nitrogen determination has always been used as a standard method for the estimation of the protein content of food.

\section{The Kjeldahl method}

This method is now internationally recognized as the reference method for measuring the protein content in milk products, and is listed as such in the Codex Alimentarius.

\section{Principle}

In 1883, Kjeldahl discovered that, by heating organic compounds in concentrated sulfuric acid, nitrogen is converted quantitatively into ammonium sulfate and can subsequently be estimated as 
ammonia by distillation and titration after addition of sodium hydroxide.

During digestion, carbon is transformed into $\mathrm{CO}_{2}$ and hydrogen into $\mathrm{H}_{2} \mathrm{O}$. Detailed information concerning the various reactions involved during digestion can be found in the review of McKenzie and Murphy (1970).

\section{Development}

Since its discovery, this method has been studied extensively and the procedure revised periodically to improve both the digestion rate and the accuracy. The objective is to convert, as quickly as possible, the totality of the organic nitrogen, even the most refractory compounds, into $\mathrm{NH}_{4}^{+}$without loss of nitrogen by pyrolytic decomposition of ammonia. It is now well established that a high digestion rate and good nitrogen recovery (over $99 \%$ ) can be achieved only with a suitable ratio of $\mathrm{K}_{2} \mathrm{SO}_{4} / \mathrm{H}_{2} \mathrm{SO}_{4}$ to reach a high boiling temperature, and with the addition of a catalyst. Several concentrations of $\mathrm{K}_{2} \mathrm{SO}_{4}$, types of catalyst (selenium, mercury, copper) and oxidizing agent $\left(\mathrm{H}_{2} \mathrm{O}_{2}\right)$ have been tested. If, with hard-to-digest compounds, mercury is certainly the most efficient catalyst, it no longer tends to be used because of current environmental concerns. Copper sulfate, which was first proposed by Rowland (1938) for milk analysis, seems to be a good alternative.

Following a study by Rexroad and Cathey (1976), recent studies on foodstuffs (Kane, 1984) and on milk (IDF, 1986) have shown that $\mathrm{HgO}$ and $\mathrm{CuSO}_{4}$ give identical results.

In the latest version of IDF Standard 20 A/1986 (1986), for the determination of nitrogen in milk by the macro-Kjeldahl method ( $5 \mathrm{ml}$ of milk), the following ratios are prescribed: $\mathrm{K}_{2} \mathrm{SO}_{4} / \mathrm{H}_{2} \mathrm{SO}_{4}=15 \mathrm{~g} / 25$ $\mathrm{ml} ; \mathrm{CuSO}_{4}, 5 \mathrm{H}_{2} \mathrm{O}_{2} \mathrm{H}_{2} \mathrm{SO}_{4}=0.05 \mathrm{~g} / 25 \mathrm{ml}$. Compared to the original $\mathrm{CuSO}_{4}$ concentration recommended by Rowland (1938) (i.e., $0.2 \mathrm{~g} / 5 \mathrm{ml}$ ), a 12-fold lower concentration was adopted to prevent the formation of ammoniacal complexes with copper, which may lead to a relative underestimation of about $1 \%$ of the nitrogen content.

It is important to bear in mind that a catalyst cannot be changed without reconsidering the whole procedure, and especially the $\mathrm{K}_{2} \mathrm{SO}_{4} / \mathrm{H}_{2} \mathrm{SO}_{4}$ ratio and the total mineralization time. It is also recommended to consider the total mineralization time given in a Standard as a minimum. The heating time should not be reduced if the clearing time (when the digest become clear) is short, as for instance with low-fat milk samples.

On the other hand, for samples with a high fat or protein content, the amount of $\mathrm{H}_{2} \mathrm{SO}_{4}$ has to be increased because organic material consumes $\mathrm{H}_{2} \mathrm{SO}_{4}$, and the total mineralization time may have to be extended if the clearing time is longer than that given in the Standard.

For routine analysis, the classical Kjeldahl flask and gas burner or electric heater with separate distillation apparatus, are progressively being replaced by block digestion and steam distillation apparatus, which give results similar to those obtained with the standard method. The traditional titration using an indicator solution can be carried out with automatic $\mathrm{pH}$ titration or specific ion electrode (Pailler, 1982). An automatic device developed by Foss Electric (DK), the Kjelfoss, which combines in a single instrument all the steps of the procedure, i.e., mineralization, distillation and titration, allows the determination of 20 samples per hour with good precision and accuracy (Grappin \& Jeunet, 1976). 


\section{Analytical performance}

When performed correctly, the Kjeldahl method is assumed to give the true nitrogen content of milk. However, many reports of collaborative studies have shown that large discrepancies between laboratories frequently occur. To improve the reproducibility, the new IDF standard requires that two accuracy tests be performed regularly. First, one test based upon the analysis of tryptophan or a similar refractory compound, e.g., phenacetin, to check the mineralization efficiency, with a percent of $\mathrm{N}$ recovery better than $98 \%$. Lysine- $\mathrm{HCl}$ is an alternative, but difficulties have been reported by Kane (1984); nicotinamide, which is also a difficult-to-digest material, does not give an excellent recovery with copper sulfate. Second, a test based on the analysis of an ammonium salt (sulfate or oxalate) is performed to check the distillation and the titration steps, with a percent of $\mathrm{N}$ recovery between 99 and $100 \%$.

To check their procedure, laboratories may take advantage of using reference materials like an $\mathrm{NH}_{4} \mathrm{H}_{2} \mathrm{PO}_{4}$ solution or a milk powder with a certified $\mathrm{N}$ content supplied, respectively, by the American National Bureau of Standards, and the European Bureau Communautaire de Référence (Brussels).

A collaborative study on the IDF Standard 20 A/1986 (Grappin \& Horwitz, 1988), carried out with the participation of 24 reporting laboratories representing 12 countries, gave, for the normal range of variation of nitrogen in milk, a repeatability relative SD of $0.5 \%$ and a reproducibility relative SD of $1 \%$.

\section{The Dumas and related methods}

In these methods, organic and inorganic nitrogen is converted into nitrogen gas which is determined by gas chromatography, volumetrically or by thermal conductivity. Commercially available are automatic apparatuses able to perform fast and reliable analyses (e.g., the Carlo Erba NA 1500 machine determines nitrogen in $3 \mathrm{~min}$ ). One machine was tested in 1974 by Lunder on casein and whole dried milk and gave reliable data. Recently, two instrument manufacturers (Leco Corp, St Joseph, Michigan, USA, and Heraeus $\mathrm{GmbH}$, Hanau, FRG) have developed automated instruments for the measurement, in 3 to $7 \mathrm{~min}$, of nitrogen by thermal conductivity.

\section{Conversion factor - Terminology}

To estimate the amount of protein in milk and milk products, it is necessary to convert nitrogen into protein, by multiplying the nitrogen content by a factor called the Kjeldahl conversion factor. A value of 6.38 for this factor, originally proposed a century ago by Hammarsten and Sebelien on the bases of the nitrogen content $(15.67 \%)$ of purified acid-precipitated casein, is generally accepted and was confirmed in the latest IDF Standard.

However, this mode of determining the protein content raises two important questions. First, the terminology "protein content" is not fully correct since the proportion of non-protein nitrogen (NPN), within and between dairy products, varies from $3-8 \%$ in milk and up to $25-30 \%$ in whey. To avoid confusion, the term "crude protein" has to be used to express the 
Table II. Protein content and Kjeldahl factors of milk (Karman \& Van Boekel, 1986). Teneur en protéines et facteurs Kjeldahl du lait (Karman \& Van Boekel, 1986).

\begin{tabular}{|c|c|c|c|c|c|}
\hline \multirow[t]{2}{*}{ Protein } & \multirow[t]{2}{*}{ Amount (g/l) } & \multicolumn{2}{|c|}{ Without carbohydrate } & \multicolumn{2}{|c|}{ With carbohydrate } \\
\hline & & $\mathrm{N} \%$ & $\begin{array}{l}\text { Kjeldahl } \\
\text { factors }\end{array}$ & $\mathrm{N} \%$ & $\begin{array}{l}\text { Kjeldah } \\
\text { factors }\end{array}$ \\
\hline$\alpha_{\mathrm{s} 1}-\mathrm{CN}$ & 10.0 & 15.77 & 6.34 & & \\
\hline$\alpha_{\mathrm{s} 2}-\mathrm{CN}$ & 2.6 & 15.83 & 6.30 & & \\
\hline$B-C N$ & 9.3 & 15.76 & 6.34 & & \\
\hline $\mathrm{K}-\mathrm{CN}$ & 3.3 & 16.26 & 6.15 & 15.67 & 6.38 \\
\hline$\gamma-\mathrm{CN}$ & 0.8 & 15.87 & 6.30 & & \\
\hline$\beta-\mathrm{Lg}$ & 3.2 & 15.68 & 6.38 & & \\
\hline$\alpha-L a$ & 1.2 & 16.29 & 6.14 & & \\
\hline $\mathrm{SA}$ & 0.4 & 16.46 & 6.07 & & \\
\hline $\lg$ & 0.8 & 16.66 & 6.00 & 16.14 & 6.20 \\
\hline PP5, 8F, 8S & 0.5 & 15.30 & 6.54 & & \\
\hline PP3 & 0.3 & 16.97 & 5.89 & 15.27 & 6.55 \\
\hline Lactoferrin & 0.1 & 17.48 & 5.72 & 16.29 & 6.14 \\
\hline Transferrin & 0.1 & 17.00 & 5.88 & 16.10 & 6.21 \\
\hline MFGM & 0.4 & 15.15 & 6.60 & 14.13 & 7.08 \\
\hline Milk & 33.0 & 15.87 & 6.30 & 15.76 & 6.34 \\
\hline
\end{tabular}

Table III. Experimental Kjeldahl factors for isolated milk protein (Karman \& Van Boekel, 1986).

Facteurs Kjeldahl expérimentaux pour des protéines du lait isolées (Karman \& Van Boekel, 1986).

\begin{tabular}{lcccc}
\hline Protein & $\begin{array}{c}\text { \% Non-protein } \\
\text { ash }\end{array}$ & $\begin{array}{c}\text { Corrected } \\
\text { N\% }\end{array}$ & $\begin{array}{c}\text { Experimental } \\
\text { Kjeldahl } \\
\text { factor }\end{array}$ & $\begin{array}{c}\text { Theoretical } \\
\text { Kjeldahl } \\
\text { factor }\end{array}$ \\
\hline & 2.16 & 15.55 & 6.43 & 6.33 \\
$\alpha_{s}$-Casein & 3.78 & 16.41 & 6.10 & 6.34 \\
$\beta$-Casein & 2.11 & 14.84 & 6.74 & 6.38 \\
$\chi$-Casein & 1.40 & 15.62 & 6.40 & 6.34 \\
Total casein & 12.60 & 14.97 & 6.68 & 6.38 \\
\hline
\end{tabular}

1. The difference between the ash content and the sum of $\mathrm{PO}_{4}$ and $\mathrm{SO}_{4}$ contents taken as non-protein ash (the $\mathrm{SO}_{4}$ content was taken for $\beta$-Lactoglobulin only).

2. Corrected for fat and water content and non-protein ash.

1. La différence entre la teneur en cendres et la somme des teneurs en $\mathrm{PO}_{4} \& \mathrm{SO}_{4}$ a été considérée comme cendres non protéiques (seule la teneur en $\mathrm{SO}_{4}$ a été prise pour la B-lactoglobuline).

2. Corrigé pour les teneurs en matière grasse et en eau et pour les cendres non protéiques. 
nitrogenous matter in milk. Its quantitative expression is represented by the amount of total nitrogen multiplied by 6.38 , and is expressed in $\mathrm{g}$ per $100 \mathrm{~g}$ (or $\mathrm{kg}$ or liter) of milk or milk product.

Second, the conversion factor is not constant, but highly dependent on the amino acid composition of the protein fraction. Recently, using the primary structure of milk proteins, Karman and Van Boekel (1986) have shown that for cow's milk, the conversion factor should be 6.34 instead of 6.38 , and different factors shoud be used for casein (6.34), paracasein $(6.29)$, rennet whey proteins (6.45), acid whey proteins (6.30), and NPN (6.30). Recently, these figures were slightly corrected by Van Boekel and Ribadeau-Dumas (1987). For individual proteins fractions, the variability of the factor is even greater (Table II). In their study, they demonstrated that experimental determination of the Kjeldahl factor on (pure) protein fractions leads to substantial discrepancies from the theoretical values obtained from amino acid sequences (Table III), mainly because it is difficult to obtain pure fractions and to accurately measure the ash content.

Even though the term "crude protein" and the conversation factor of 6.38 were recently confirmed in the Codex Alimentarius for milk and milk products, a more accurate definition and methodology for measuring the "true" protein content should be promoted.

\section{The indirect methods}

\section{Definition and characteristics}

\section{Definition}

According to Grappin (1984), a method of analysis is designated "indirect" when it does not measure directly the component it is intended to quantify, but instead measures one or more quantities or properties which are functionally linked to that component. For instance, the Amido Black method is an indirect method because it does not directly determine the protein content, but measures the amount of dye that is bound to proteins. The same holds for instrumental methods such as IR techniques. As a consequence, indirect methods require standardization against a reference method to convert the instrumental signal into component concentration. We may point out that, following this definition, the Kjeldahl method may also be considered an indirect method, even though it is accepted as a reference for the determination of the protein content in milk products.

\section{Analytical attributes and calibration}

Because of the influence of sample matrix, the quantities or properties measured by indirect methods are not usually exactly proportional to the component concentration, therefore introducing systematic errors in the final test result.

Figure 1 illustrates the various criteria involved in the overall accuracy of an indirect method (IDF, 1987). If we except random errors (i.e., instrument repeatability), systematic errors can be divided into two components :

- the exactness of calibration, which relates to the closeness of agreement, at each concentration level, between the indirect method value, represented by the equation of the observed line, and the estimated mean of the true values of all the individual samples at the corresponding level.

- the accuracy of estimate, or simply accuracy, which relates to the closeness 
of agreement between individual test results which are obtained with the instrument exactly calibrated and with the reference method. The ellipse in Figure 1, which represents the $95 \%$ confidence interval within which the true value is expected to lie for any result of the indirect method, illustrates the accuracy of the indirect method. The mathematical expression of the accuracy is given by the residual standard deviation $s_{y, x}$. This important attribute of an indirect method gives the best estimate of the predicting value of the indirect method.

To counteract the influence of known or unknown, which are common to a whole population of samples, the indirect method will have to be calibrated. By definition (IDF, 1987), the calibration of an instrument concerns the adjustment of the instrument signal so that, at each level of the component concentration, the mean of individual test result given by the instrument is closely approximate to the true value of the component concentration. Practically, the calibration of an indirect method can be achieved by calculating the relationship between the component concentration obtained by the reference method on a set of samples or by reference materials, and the instrument signal.

\section{The dye-binding methods}

Following the fundamental work of Fraenkel-Conrat and Cooper (1944) on the use of dyes for the determination of acid and basic groups in proteins, quantitative determination of milk protein by dye-binding was introduced in 1956 by

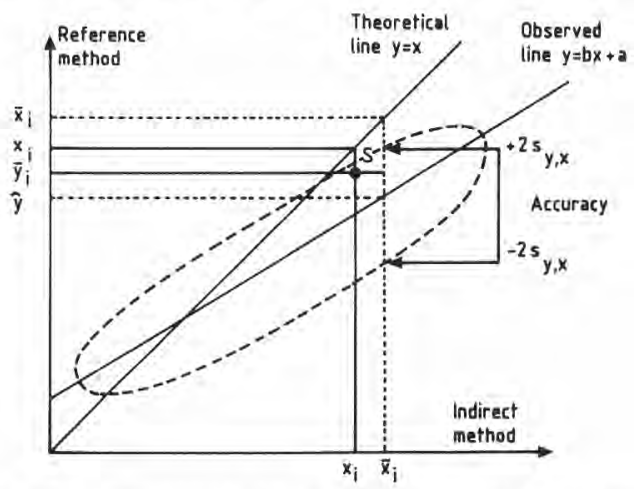

Fig. 1. Breakdown of the overall accuracy of an indirect method (IDF, 1987). $x_{i}=$ single instrumental value; $\bar{x}_{i}=$ arithmetic mean of several determinations of sample $S$ with the instrument; $\hat{y}=$ estimated mean reference value for all the samples with an instrument level $\bar{x}_{i} ; \bar{y}_{i}=$ "true value" of the component to be measured for sample $S$ Sy, $x=$ standard deviation from the regression. The mathematical model of the components of the total error on $x$ is :

$$
\begin{aligned}
\left(x-\bar{y}_{i}\right) & =\left(x_{i}-\bar{x}_{i}\right)+ \\
\text { overall accuracy } & \text { repeatability } \begin{array}{l}
\left(\bar{x}_{i}-\bar{y}_{i}\right) \\
\text { accuracy of the mean } \\
\left(x_{i}-\bar{y}_{i}\right)+\left(\hat{y}-\bar{y}_{i}\right) \\
\text { exactness of accuracy calibration }
\end{array}
\end{aligned}
$$

Décomposition de la précision globale d'une méthode indirecte (IDF, 1987) $\mathrm{x}=$ valeur instrumentale singulière; $x_{i}=$ moyenne arithmétique de plusieurs dosages effectués sur l'échantillon $S$ avec l'instrument; $y=$ valeur de référence moyenne estimée avec un niveau instrumental $x_{i} ; y_{i}=$ "valeur exacte" correspondant au composé à doser dans l'échantillon $S ; S y_{1} x=$ écart type de la régression. Le modèle mathématique des composants de l'erreur totale sur $x$ est :

$$
\begin{aligned}
\left(x-\bar{y}_{i}\right)=\frac{\left(x_{i}-x_{i}\right)}{\text { pécision globale }} \\
\text { rétabilité }
\end{aligned}+\begin{aligned}
& \left(\bar{x}_{i}-\bar{y}_{i}\right) \\
& \text { précision de la moyenne } \\
& \left(\bar{x}_{i}-\hat{y}\right)+\left(\hat{y}-\bar{y}_{j}\right) \\
& \text { exactitude de précision calibration }
\end{aligned}
$$


Schober and Hetzel and by Udy. This method was the first routine method available for breeding programs and payment schemes, and is still used for control in the dairy industry. A recent brief review of the method was published in 1987 by Van Reusel and Klijn in the IDF monograph on rapid indirect methods for measurement of the major components of milk.

\section{Principle}

The dye-binding procedures used for milk protein testing employ different azosulfonic acid dyes : $\mathrm{Cl}$ Acid Black 1 (or Amido Black), $\mathrm{Cl}$ Acid Orange 12, and $\mathrm{Cl}$ Acid Orange 10 (or Orange G). The mechanism of the reaction between the dye and the proteins is now relatively well, if not fully, understood. In acid buffer solution below the isoelectric point of the proteins, the positive charges of both the terminal amino groups, and the histidine, arginine and lysine residues, combine in a stoichiometric interaction with the negative sulfonic group of the dye to form an insoluble dye-protein complex. In addition, Lakin (1974) has shown that hydrophobic interactions occur between free and bound anionic dyes.

The differences between dyes, with respect to their sensitivity (change of absorbancy per unit change of protein weight), are partly associated with their abilities to form hydrophobic interactions. Amido Black has the highest sensitivity followed by Acid Orange 12 and Acid Orange 10.

The quantity of dye bound per unit weight of protein, called the dye-binding capacity (DBC) of proteins, is dependent on the ratio of dye over proteins. Several workers (Fraenkel-Conrat \& Cooper, 1944; Dolby, 1961) have shown that an excess of dye should be present in solution to get both a complete reaction between dye and proteins and a proportionality between milk protein content and the amount of dye which precipitates. Similarly, if the dye/protein ratio is too high, the DBC increases (Alais et al., 1961; Ashworth \& Chaudry, 1962). Orange $G$ seems to have a better stoichiometric reaction than Amido Black (Dolby, 1961; Ashworth \& Chaudry, 1962). The various milk proteins or nitrogen fractions do not react in a similar way with the dye. Several authors have found similar results concerning the DBC of milk protein fractions (Alais et al., 1961; Ashworth \& Chaudry, 1962; Tarassuk et al., 1967; McGann, 1978). In Table IV are reported the findings of Tarassuk et al. (1967) and Ashworth and Chaudry (1962). it is important to point out that whey proteins have a higher DBC (ca. $27 \%$ more) than the caseins and that NPN does not bind any dye, rather, it remains in the supernatant (Alais et al., 1961; Tarassuk et al., 1967).

\section{Analysis}

The measurement of protein content is based upon the determination of the amount of unbound dye after removal of the dye-protein precipitate. Provided that the ratio of dye to protein remains within certain limits, a linear relationship exists between the protein content and the quantity of unbound dye. However, McGann and Murphy (quoted in McGann, 1978) have demonstrated that, with Acid Orange 12, the relationship between absorbance and protein content is best given using a quadratic equation. A similar observation was made recently in our laboratory (unpublished data) for the Amido Black method with different kinds of milk samples : individual milk, reconstituted or ultrafiltrated milk samples. 
The procedure of the dye-binding method involves four steps (Mc Gann, 1978) :

- The sample (between 0.5 and $1.0 \mathrm{ml}$ ) is thoroughly mixed with a constant volume of dye solution (about $20 \mathrm{ml}$ ) at a $\mathrm{pH}$ of 2.2-2.4, containing phosphatecitrate buffer for the Amido Black method and phosphate-acetate-propionate buffer for the Udy method using Acid Orange 12.

- The second stage involves a rapid partial equilibrium (ca. $5 \mathrm{~s}$ ) between dye and proteins to react and form an insoluble complex.

- A clear supernatant is obtained by filtration or centrifugation.

- The absorbance of the supernatant is measured in a spectrophotometer, using usually a short path-length flow-through cuvette at a fixed wavelength, between 550 and $610 \mathrm{~nm}$ for Amido Black, and 480 $\mathrm{nm}$ for Acid Orange 12. To obtain the protein content, the instrument has to be calibrated against the reference method according to the principle given p. 372 , and a linear regression line is normally obtained within the normal range of milk protein content $(2.5-4.5 \%)$.

To improve the reproducibility of results between laboratories, a centralized system of calibration using reference milk samples has been used, for instance, in France (Grappin \& Jeunet, 1976), Poland (Michalak \& Deskowicz, 1975) and Australia (Clarke, 1979). International standards for dye-binding methods are now available from AOAC and IDF.

\section{Instrumentation}

To perform a protein test by dye-binding, no specific instrument is necessary except a centrifuge and a spectrophotometer. For routine determination in a central testing laboratory, fully automated equipment using Amido Black was first developed in

Table IV. Dye-binding capacity of milk proteins, mg Amido Black (AB) or Orange G (OG) per g protein. Within brackets : ratio to casein.

Capacité de fixation du colorant par les protéines du lait, en mg de Noir-Amido (AB) ou Orangé G (OG) par g de protéines. Entre parenthèses : rapporté à la caséine.

Tarassuk et al. (1967)

$A B$
Ashworth and Chaudry (1962) $O G$

\begin{tabular}{|c|c|c|c|c|c|c|c|}
\hline Milk & & 350 & $(1.08)$ & 179 & $(0.95)$ & 354 & $(1.04)$ \\
\hline Casein & & 325 & & 189 & & 339 & \\
\hline Whey proteins & & 410 & $(1.26)$ & 247 & $(1.31)$ & 447 & (1.32) \\
\hline Proteose-peptones & & & & & & 350 & (1.03) \\
\hline \multicolumn{8}{|l|}{ Casein } \\
\hline & alpha & 345 & $(1.06)$ & 199 & $(1.05)$ & 373 & $(1.10)$ \\
\hline & beta & 290 & $(0.89)$ & 170 & $(0.90)$ & 318 & $(0.94)$ \\
\hline & kappa & 310 & $(0.95)$ & 193 & (1.02) & 359 & (1.06) \\
\hline \multicolumn{8}{|l|}{ Whey proteins } \\
\hline & alpha lactalbumin & 440 & $(1.35)$ & & & & \\
\hline & beta lactoglobulin & 425 & (1.31) & 252 & (1.33) & 456 & $(1.35)$ \\
\hline & serum albumin & 430 & (1.32) & & & & \\
\hline & immunoglobulins & 320 & $(0.98)$ & & & & \\
\hline
\end{tabular}


Holland in 1960 and then in several other European countries, particularly in France. The Dutch apparatus used in 1976 by the laboratory of Zutphen, was capable of analyzing as many as 10000 samples per hour. This equipment has been replaced gradually by IR techniques.

Specific manual equipment has been marketed since 1960 : the Udy system (Udy Analyser Co., Boulder CO., USA), using Acid Orange 12, and the Pro-Milk MKII (Foss Electric, Hillerod, DK) and Prot-o-Mat (Funke-Gerber, Berlin, DE), using Amido Black.

Factors affecting the accuracy of protein determination in milk

Various factors affecting the selection of the dye to be used, the methodology and the reaction conditions have been reviewed by Sherbon (1978) and Tarassuk et al. (1967). Great care should be taken to ensure the purity of the dye, especially Amido Black which sometimes contains a large proportion of sodium chloride (Lakin, 1970) and traces of other dyes. Amido Black $10 \mathrm{~B}$ is generally recommended for electrophoresis. On the other hand, Orange 12 can be purified (see AOAC standard).

Experience has shown that, despite the fact that the various milk protein fractions have a slightly different DBC (Table IV), the main source of discrepancy between dye-binding and Kjeldahl methods is the variation of NPN content. In a population of individual milk samples, the accuracy $\mathrm{SD}\left(\mathrm{s}_{\mathrm{y}, \mathrm{x}}\right)$ is lowered by $60 \%$ when true protein is used for reference instead of crude protein (Fig. 2). Variations in the ratio NPN/Total $N$ in milk almost entirely explain the differences in calibration observed throughout the year and also between goat and cow milk (Lakin, 1970; Grappin \& Jeunet, 1976; Grappin et al., 1979). However, for individual goat milk Grappin and Jeunet (1979) have shown than $67 \%$ of the differences between Kjeldahl true protein contents and Amido Black readings are explained by the variation of the ratio whey protein/true protein in milk (Fig. 3). As expected, a slight but significant influence of mastitis on accuracy has been found by Grappin et al. (1970) and Waite and Smith (1972). For instance, on quarter milk samples, an increase of $1 \mathrm{log}$ somatic cell count increases the Amido Black result by a relative $0.47 \%$ (Grappin et al., 1970).

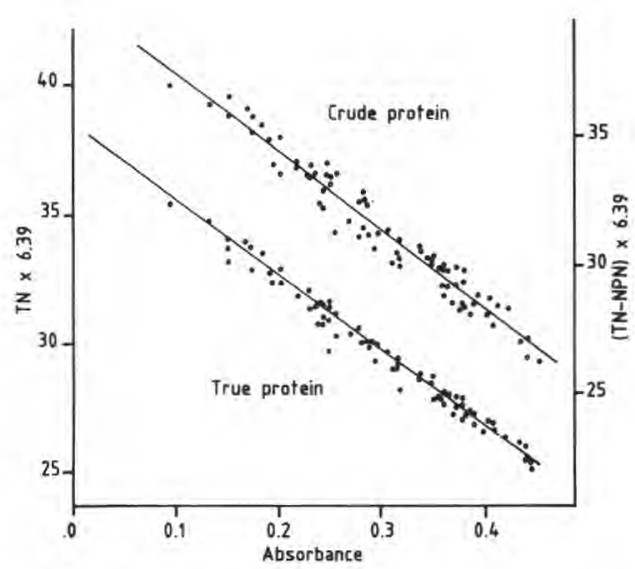

Fig. 2. Determination of true protein content and crude protein of individual milk samples by the Amido Black dye-binding method (IDF, 1987).

True protein : $r=-0.994 s_{y, x}=0.31 \mathrm{~g} / \mathrm{kg}$

Crude protein : $r=-0.985 s_{y, x}=0.51 \mathrm{~g} / \mathrm{kg}$.

Détermination de la teneur vraie et de la teneur brute en protéines d'échantillons individuels de lait par la méthode au Noir Amido (IDF, 1987).

Teneur vraie en protéines : $\mathrm{r}=-0.994 \mathrm{~s}_{\mathrm{y}, \mathrm{x}}=$ $0,31 \mathrm{~g} / \mathrm{kg}$

Teneur brute en protéines : $\mathrm{r}=-0.985 \mathrm{~s}_{\mathrm{y}, \mathrm{x}}=$ $0,51 \mathrm{~g} / \mathrm{kg}$. 
Analytical performance

Precison : several collaborative studies have been undertaken to evaluated the precision parameters of the dye-binding methods for milk protein testing (Sherbon, 1975; Grappin et al., 1980). A repeatability value of $0.03 \mathrm{~g} / 100 \mathrm{~g}$ can easily be achieved by experienced laboratories. Concerning reproducibility, the relatively poor result of $R=0.215$ $\mathrm{g} / 100 \mathrm{~g}$, found by Grappin et al. (1980), can be dramatically improved $(R=0.068)$ when standard materials are used for instrument calibration (Grappin, 1984).

Accuracy : according to the definition given p. 372 , milk protein content can be estimated with a SD $\left(x_{y, x}\right)$ varying from $0.03 \mathrm{~g} / 100 \mathrm{~g}$ to $0.06 \mathrm{~g} / 100 \mathrm{~g}$, according the origin of the milk (individual or herd

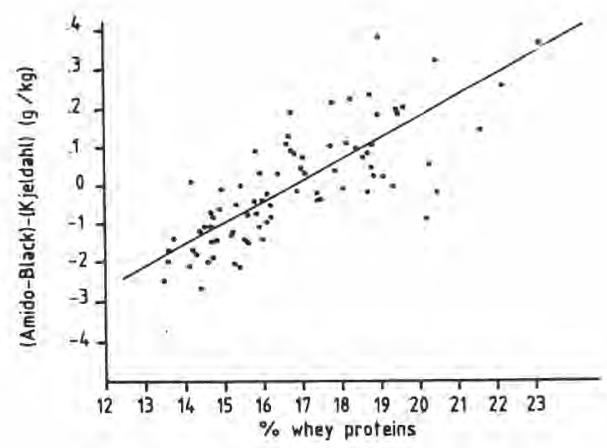

Fig. 3. Relationship between the differences : (Amido Black readings-true protein Kjeldahl values) ( $y$ axis) and the percentage of whey protein in true proteins ( $x$ axis) of 81 individual goat milk samples (Grappin \& Jeunet, 1979). Coefficient of correlation : $r=0.82$.

Relation entre les différences: (lectures NoirAmido - teneur vraie Kjeldahl) (axe des y) et le pourcentage de protéines du lactosérum dans les protéines vraies (axe des x) pour 81 échantillons de lait individuel de chèvre (Grappin \& Jeunet, 1979).

Coefficient de corrélation : $r=0,82$. milk) and the method used (manual or automatic).

\section{Application to dairy products}

The dye-binding methods are also applicable to a large variety of dairy products, like cheeses (Steinsholt, 1976), chocolate drinks, cultured buttermilk and half and half (Sherbon \& Luke, 1968), non-fat dry milk and ice cream (Sherbon \& Luke, 1969) and wheys (Roeper \& Dolby, 1971). It is clear that, for each type of product, the procedure has to be adapted and that a specific calibration is required to reflect both the modification in the procedure (volume ratio of test sample/dye solution) and the possible alteration of the DBC of the protein mixture following heat treatment or proteolysis.

\section{The infra-red method}

\section{Basic principle of IR measurements}

The IR spectrum

Three regions characterize the IR spectrum according to the wavelength or wavenumber of the radiation : the near IR region (NIR) from $0.7 \mu \mathrm{m}$ to $2.5 \mu \mathrm{m}$ (from $14285 \mathrm{~cm}^{-1}$ to $4000 \mathrm{~cm}^{-1}$ ), the mid IR region (MIR), from $2.5 \mu \mathrm{m}$ to $25 \mu \mathrm{m}$ (4000 $\mathrm{cm}^{-1}$ to $400 \mathrm{~cm}^{-1}$ ) and the far IR region, from $25 \mu \mathrm{m}$ up to $100 \mu \mathrm{m}$ (from $400 \mathrm{~cm}^{-1}$ to $100 \mathrm{~cm}^{-1}$ ). The energy of electromagnetic radiation is proportional to the frequency of the radiation, i.e., inversely proportional to the wavelength. When a molecule is submitted to IR radiation, energy will be absorbed only if the frequency of the radiation corresponds to the frequency of one of the fundamental vibrations of the molecule (stretching vibrations at high frequencies and bending deformations at low frequencies). 
The vibration energy which characterizes a chemical group (e.g. $\mathrm{C}-\mathrm{H}, \mathrm{O}-\mathrm{H}, \mathrm{C}=\mathrm{O}$ ) is dependent upon both the bond strength, and the masses of the two atoms of the group. Fundamental vibrations of the molecules take place mainly in the MIR region, and absorption in the NIR occurs at wavelengths corresponding either to harmonic frequencies, or to combination frequencies of the fundamental vibrations.

These NIR absorption bands are generally quite broad, allowing use of rather large spectral pass bands for measurements. Their intensities are usually weak compared to the signals obtained in the MIR region from fundamental vibrations of the molecules. However, they are sufficiently important to allow quantitative analysis. Because NIR bands are less specific for a given molecule than wavelengths in MIR, one can anticipate that quantitative analysis of a specific component will require more wavelengths to obtain accurate measurements.

\section{Quantitative analysis}

The measurement of the IR energy absorbed by a sample can be made either in the transmission mode, if the product is in solution or is sufficiently transparent to IR radiation, or in the reflection mode for opaque or solid samples. Most of the MIR equipment designed for liquid samples measures the transmitted light directly, while NIR instruments are usually built to measure the IR light which is either diffusely reflected from the product surface for solid samples or from the surface of the sample holder for liquids, or transmitted through a cuvette for liquids.

With a single component solution, the amount of IR energy that is absorbed by the sample (absorbance) is exponentially proportional to the component concentration and follows the Beer-Lambert law. If $\mathrm{I}_{0}$ is the intensity of the incident beam and $I$ the intensity of the transmitted or reflected beam, the absorbance is $A_{\lambda}=$ $\log I_{0} / I=E_{\lambda}$.C.I, where the ratio $I / I_{0}$ represents either the transmittance or the reflectance, $E$ the extinction coefficient of the component, $\mathrm{C}$ the concentration, $\lambda$ the measurement wavelength and $I$ the path length of the cell, for transmittance measurement.

The absorbance of $n$ absorbing components is then expressed by the equation:

$A_{x}=E_{x 1} \cdot C_{1}+E_{x 2} \cdot C_{2}+\ldots+E_{x n} \cdot C_{n}$ where $\mathrm{C}_{1}, \mathrm{C}_{2} \ldots \mathrm{C}_{n}$ are the concentrations of the $n$ components,

and $E_{x 1}, E_{x 2} \ldots E_{x n}$ the absorptivities of the $n$ components at the wavelengths $x_{1}$, $\mathrm{x}_{2}, \ldots \mathrm{x}_{n}$.

In conventional MIR instruments, to correct any variation of the system response (source brightness, temperature of sample, soil on the cuvette, etc.) and to

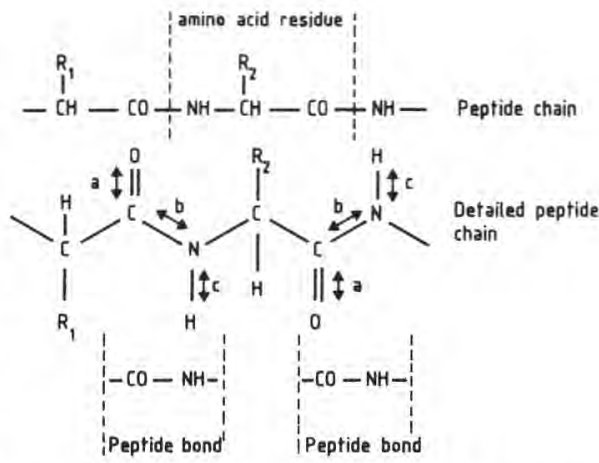

Fig. 4. Mid-IR Absorption bands of the peptide bond. $\longleftrightarrow$, direction of the light-induced dipole; $R_{1}, R_{2}$, amino acid side chains.

Bandes d'absorption de la liaison peptidique dans I'IR moyen. $\leftrightarrow$, direction du dipôle induit par la lumière; $R_{1}, R_{2}$, chaînes latérales des acides aminés. 
diminish, as much as possible, the influence of interfering components like water, the measurements are made by reference to the amount of IR energy absorbed, either by water at the same wavelength as the measuring wavelength, or by the sample at a close wavelength at which there is only a slight absorption by the component being measured. For NIR instruments using reflectance, the reference is usually obtained by the intensity of the incident beam reflected by a ceramic disk.

\section{Analysis of proteins by MIR transmission}

Since the work of Goulden in 1964, who first studied the analysis of milk by MIR absorption, a large number of papers assessing new instruments, or dealing with more fundamental works, have been published.

In the IDF monograph on indirect methods for milk analysis (1987), Biggs et al. have reviewed the current status of knowledge concerning this technique. Much of the information given in this chapter is drawn from this monograph. A comprehensive work on this method has been prepared by Sjaunja (1982).

\section{Principle}

In MIR, there is a strong absorption band, called "amide II", at ca. $6.46 \mu \mathrm{m}$ (1 550 $\mathrm{cm}^{-1}$ ) by the peptide bond. This absorption originates from $\mathrm{C}-\mathrm{N}$ stretching vibration $(40 \%)$, and from $\mathrm{N}-\mathrm{H}$ bending deformation (60\%) (Fig. 4). The peptide bond also shows other absorption bands at near $1650 \mathrm{~cm}^{-1}(6.1 \mu \mathrm{m}$, "amide II", due mainly to $\mathrm{C}=0$ stretching vibration) and at $3300 \mathrm{~cm}^{-1}(3.0 \mu \mathrm{m}, \mathrm{N}-\mathrm{H}$ stretching vibration). As illustrated by Figure 5, the determination of protein concentration in milk is based upon the "specific" absorption of the peptide linkages at $6.46 \mu \mathrm{m}$. Although proteins are the major absorbing compounds at this wavelength, the absorbance is influenced to a greater or lesser extent by the other major milk compounds (fat and lactose) and by minor soluble elements. As most of the instruments are designed to make simultaneous determination of fat, protein and lactose (and sometimes water), the best accuracy for protein determination will be obtained if the primary protein signal is corrected for the absorption by fat and lactose at the protein wavelength. With modern instruments, automatic correction is achieved by setting internal correction

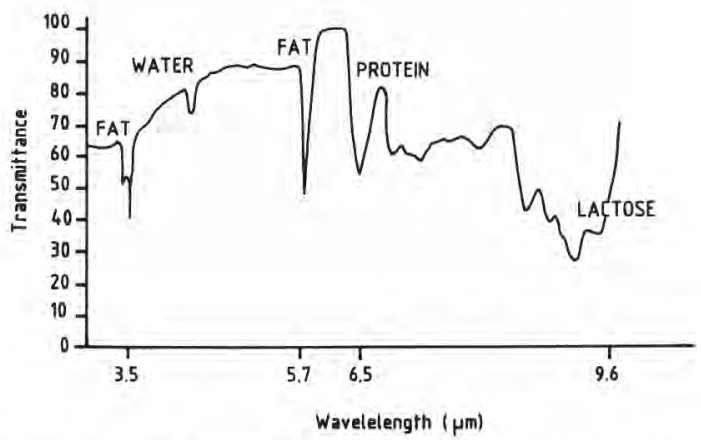

Fig. 5. The infra-red transmission spectrum of milk versus water (courtesy of Multispec Ltd, IDF, 1987).

Spectre de transmission IR du lait contre l'eau (courtoisie de Multispec Ltd; IDF, 1987). 
factors for each component at each wavelength. To minimize the light scattering influence of fat globules, the sample has to be homogenized prior to analysis to reduce the globule size below $1 \mu \mathrm{m}$.

\section{Analysis}

A warmed sample $\left(40^{\circ} \mathrm{C}\right)$, thoroughly mixed, and if necessary blended and/or diluted, is pumped through a 1,2 or 3 stage valve homogenizer or an ultrasonic homogenizer. The specific wavelengths are focused through the cell containing the sample and the infra-red radiation is chopped by a half-section mirror to produce alternating sample and reference signals. The difference between the reference and the sample signals is then collected by an IR detector and the signal output is processed by a log/lin converter and corrected for interference. Component concentration is finally displayed on the instrument. Before analysis, the instrument must be calibrated according to the principle given p. 372 . Detailed calibration procedures are given by instrument manufacturers and a provisional international standard (IDF, 1988) has been produced by an IDF/ISO/AOAC group of experts.

\section{Instrumentation}

Following the pioneering work of Goulden, the first commercially available IR instrument allowing the direct measurement of fat, protein and lactose in milk, was a conventional double beam spectrophotometer with two cells (a reference cell with water and a sample cell), with a servosystem and a diffracting grating. This instrument, named Infra-Red Milk Analyzer (IRMA), was manufactured by Grubb Parsons (UK). With the outstanding progress made during the last 20 years in electronics, interference narrow band filters and microprocessors, simpler, more reliable, automatic and accurate instruments are now available. All modern instruments are now equipped with a single cell and optical filters. They may utilize either a single or a double beam optical system, and may use either electronic ratioing or a servo system to estimate the $\mathrm{I} / \mathrm{I}_{0}$ ratio. Figure 6 illustrates different optical systems used in IR instruments and Table 5 gives the main characteristics of commercial instruments currently available for the analysis of milk and milk products.

Another kind of instrument using an interferometer for wavelength discrimination, and known as Fourier Transform infra-red spectrometer (FT-IR), is currently being evaluated in our laboratory, as well as in other research centers. Compared to other instruments, it has the advantage of providing high signal/noise ratio, high energy, accurate frequency measurement and rapid scan, making spectral subtraction a useful feature and allowing the use of a full spectrum, instead of a few wavelengths.

Factors affecting the accuracy of protein determination in milk

Physico-chemical factors : if we exclude the influence of instrumental factors like temperature, linearity, water vapor in the optical console, homogenization efficiency, etc. and if we assume that the instrument is correctly calibrated (including the correction for fat and lactose contents), the accuracy of milk protein testing will be mainly influenced by the variation in the proportion of NPN and by the presence of carboxylic acids. The relationship between infra-red absorption at $6.46 \mu \mathrm{m}$ and true protein concentration measured by Kjeldahl is relatively independent of the amino acid composition of the protein, since the ratio $N$ content 
Table V. Major characteristics of mid infra-red instruments marketed since 1965 (IDF, 1987)

\begin{tabular}{|c|c|c|c|c|c|c|c|c|c|c|}
\hline Manufacturer & Instrument & Year & $\begin{array}{l}\text { No of } \\
\text { cell }\end{array}$ & $\begin{array}{l}\text { Beam } \\
\text { system }\end{array}$ & $\begin{array}{l}\text { Measu- } \\
\text { ment } \\
\text { system }\end{array}$ & \multicolumn{2}{|c|}{$\begin{array}{l}\text { Wavelength } \\
\text { system }\end{array}$} & \multicolumn{2}{|l|}{$\begin{array}{l}\text { Homoge- } \\
\text { nization } \\
\text { stages }\end{array}$} & Notes \\
\hline Grubb Parsson, UK & IRMA & 1965 & 2 & Double & Servo & \multirow{2}{*}{\multicolumn{2}{|c|}{$\begin{array}{l}\text { Grating } \\
\text { Optical filter }\end{array}$}} & $-F$ & Fat, protein, lactose & Obsolete \\
\hline - & Mini IRMA & 1978 & 2 & - & Ratio & & & $-F$ & $\begin{array}{l}\text { Fat, protein, lactose, } \\
\text { water }\end{array}$ & - \\
\hline Foss Electric, DK & Milko-Sacn 300 & 1974 & 1 & - & Servo & - & - & 1 & Fat, protein & - \\
\hline - & Milko-Scan 203 & 1975 & 1 & - & - & - & - & 1 & Fat, protein, lactose & \\
\hline - & $\begin{array}{l}\text { Milko-Scan 102/101 } \\
104\end{array}$ & 1979 & 1 & Single & Ratio & 一 & - & 2 & $\begin{array}{l}\text { Fat, protein, lactose, } \\
\text { water }\end{array}$ & \\
\hline - & Milko-Scan 203B & 1979 & 1 & Double & Servo & - & - & 2 & Fat $A$, protein, lactose & \\
\hline - & Milko-Scan 103B & 1980 & 1 & Single & Ratio & - & - & 2 & Fat B, protein, lactose & \\
\hline - & Milko-Scan 104 AVB & 1961 & 1 & - & - & - & - & 2 & $\begin{array}{l}\text { Fat } A \text {, fat } B \text {, protein } \\
\text { lactose }\end{array}$ & \\
\hline - & Milko-Scan 104 Auto & 1983 & 1 & - & - & - & - & 3 & See Milko-Scan 104 & \\
\hline - & Milko-Scan Speed & 1983 & 1 & - & - & - & - & 3 & See Milko-Scan 104 & \\
\hline - & $\begin{array}{l}\text { Milko-Scan } 605 \\
\text { lactose }\end{array}$ & 1984 & 1 & - & - & - & - & 3 & Fat A, fat B, protein, & \\
\hline - & $\begin{array}{l}\text { Milko-Scan 133/133A } \\
133 B\end{array}$ & 1985 & 1 & - & - & - & - & 1 & $\begin{array}{l}\text { Fat } A \text { or/and B, protein, } \\
\text { lactose }\end{array}$ & $\begin{array}{l}\text { Recriculating } \\
\text { homogeneization }\end{array}$ \\
\hline REIL & Milko-Scan 104 A/B & 1986 & 1 & Single & Ratio & - & - & 4 & Fat $A$, fat $B$, protein, lactose & \\
\hline Multispec, UK & Multispec & 1977 & 1 & Double & Servo & - & - & 2 & Fat $A$, fat $B$, protein, lactose & \\
\hline - & Multispec Auto & 1978 & 1 & - & - & - & - & 2 & Fat $A$, fat $B$, protein, lactose & \\
\hline - & Micro-null & 1984 & 1 & - & - & - & - & 3 & Fat $A$, fat $B$, protein, lactose & \\
\hline - & Multispec II & 1984 & 1 & - & - & - & - & 2 & Fat $A$, fat $B$, protein, lactose & \\
\hline 一 & Dairy Lab & 1986 & 1 & Single & Ratio & - & - & 2 & fat $A$, fat $B$, protein lactose & \\
\hline \multicolumn{4}{|c|}{ (with the technical assistance of Foss Electric) } & & & & & & and others & \\
\hline
\end{tabular}




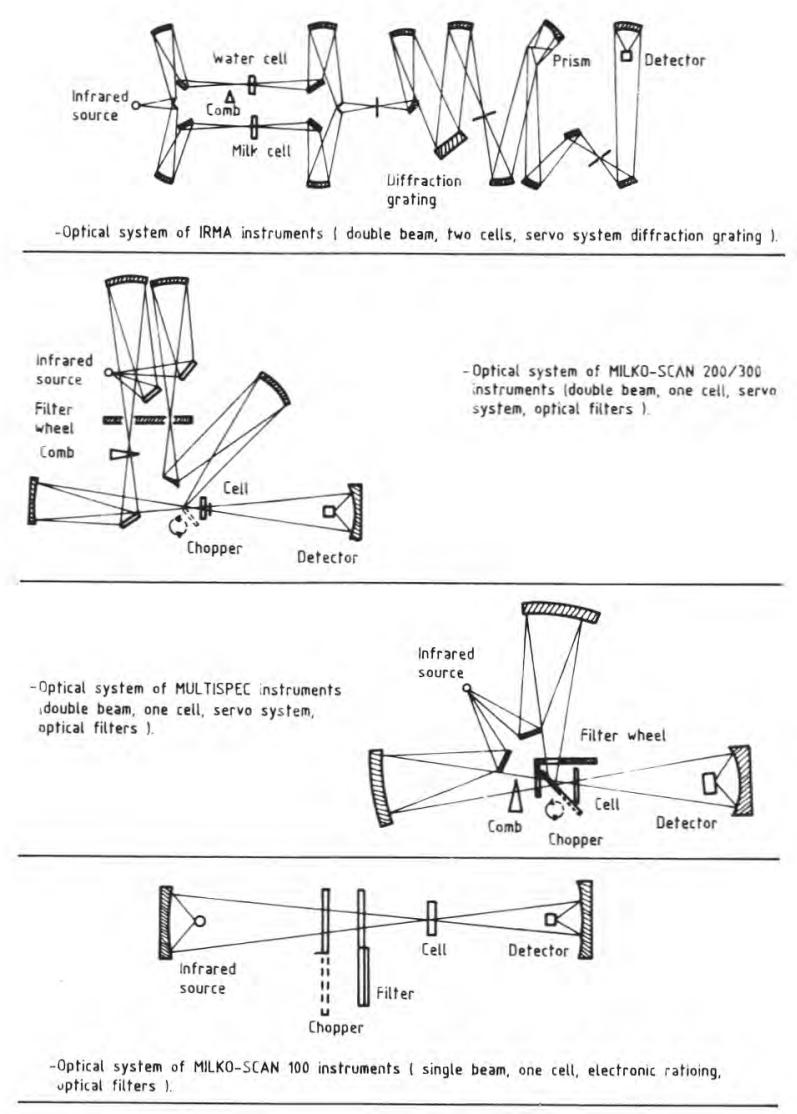

Fig. 6. Optical systems of different mid-IR instruments (IDF, 1987).

Systèmes optiques des différents instruments opérant dans I'IR moyen (IDF, 1987).

/number of peptide linkages is relatively constant. On the other hand, because the NPN fraction is not measured by infrared, any variation in the proportion of NPN will influence the accuracy of an instrument calibrated in crude protein (total $N \times 6.38$ ).

The presence of ionized carboxyl group, COO-, gives rise to an absorption band at the protein wavelength. The main indigenous source of such groups is citrate. Gaudillere and Grappin (1982) and Sjaunja and Anderson (1985) have shown that natural variations in the citrate content of individual milks explain between $40 \%$ and $60 \%$ of the difference between IR and Kjeldahl true protein results, and an increase of $0.01 \%$ unit of citric acid changes the protein reading by $+0.075 \mathrm{~g} / 100 \mathrm{~g}$.

The formation of carboxylic acids by fermentation of lactose may also cause interference absorption at the protein wavelength (Goulden, 1964). Similarly, it has been demonstrated that lipolysis induces an increase of the protein signal 
by 0.01 percent unit per millimole of free fatty acid (Sjaunja, 1982). Grappin and Jeunet (1979) have clearly demonstrated that in fact most of the interfering compounds are present in the milk soluble phase (Fig. 7).

- Biological factors : any biological factor (e.g., stage of lactation, mastitis, breed, species, feeding, season, etc.), that is known to influence one of the physicochemical characteristics mentioned above, will in its turn cause systematic errors in protein measurement by IR methods. According to the review of Biggs et al. (1987), only the influence of few factors has been demonstrated clearly. Goat milk, which has a lower proportion of citrate, requires a different calibration for true protein than cow milk (Grappin et al., 1979). Season/feeding, as well as species (goat vs. cow) or breed (Jersey vs. others)

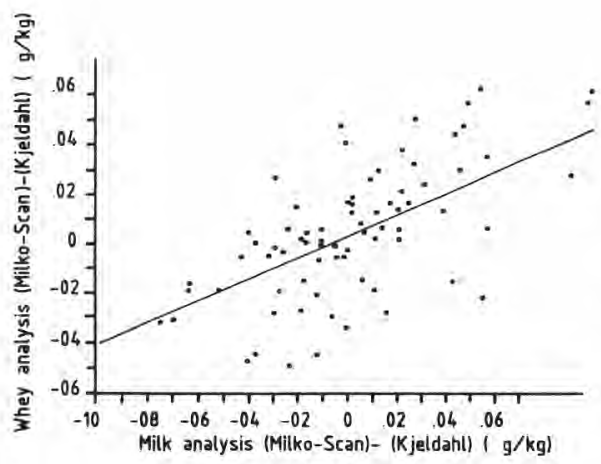

Fig. 7. Relationship between the differences Milkoscan protein readings-true protein Kjeldahl values obtained on 81 individual goat milk samples $(x)$ and on the corresponding whey samples (y) (Grappin \& Jeunet, 1979).

Coefficient of correlation $r=0.65$.

Relation entre les écarts taux de protéines Milkoscan - taux de protéines vraies Kjeldahl pour 81 échantillons individuels de lait de chèvre $(\mathrm{x})$ et pour les échantillons correspondants de lactosérum ( $\mathrm{y}$ ) (Grappin \& Jeunet, 1979).

Coefficient de corrélation : $\mathrm{r}=0,65$. which influence the proportion of NPN in milk, will have a significant influence on the accuracy of the method when the apparatus is calibrated for crude protein (Grappin \& Jeunet, 1979; Sjaunja, 1982). Whenever possible, adjustment of the instrument calibration will therefore be necessary.

\section{Analytical performance}

Since the first instrument tested by Goulden in 1964, real progress in the performance of instruments has been achieved (Biggs, 1979).

\section{Repeatability}

With modern instruments, an excellent repeatability SD of $0.02 \mathrm{~g} / 100 \mathrm{~g}$, for milk fat, protein and lactose testing is now commonly obtained.

\section{Accuracy}

Following the definition given p. 372, milk protein content can be estimated with a $\mathrm{s}_{\mathrm{y}, \mathrm{x}}$ varying from $0.08 \mathrm{~g}$ pour $100 \mathrm{~g}$ for individual milk to $0.04 \mathrm{~g}$ for $100 \mathrm{~g}$ for herd milk.

One can assume than with silo milk, accuracy will be closely related to the repeatability of both the Kjeldahl and the IR methods.

\section{Analysis of proteins by NIR reflection}

Rapid measurement of the chemical composition of food products by NIR reflection spectroscopy has been studied and used mainly in the field of cereals and plant analysis. Despite the fact that the application of this technique to milk product analysis was investigated by Goulden as early as in 1957, it has received limited attention from scientists. 
With the development of reliable commercial instruments, the dairy industry is now increasingly using NIR methods to monitor the quality of dairy products : e.g., moisture of milk powder, moisture, protein and fat content of fresh cheese and yogurt (Egli \& Meyhack, 1984).

\section{Principle}

Milk has an NIR spectrum which is very similar to water, and the determination of wavebands which are "specific" to milk proteins can be achieved only by mathematical treatment of a collection of milk spectra. From the reflectance values recorded by the instrument at the different wavelengths available (for instance up to 19 with the Technicon Infra-Analyzer 450) and the corresponding component concentration measured by a reference method, the most common way of selecting wavelengths is to calculate a step-by-step multiple regression using the equation :

$$
\begin{gathered}
C=K_{1} \log \left(1 / R_{1}\right)+K_{2} \log \left(1 / R_{2}\right)+\ldots \\
+K_{n} \log \left(1 / R_{n}\right)+K_{0}
\end{gathered}
$$

where $\mathrm{C}$ is the component concentration, $K$ is a constant equivalent to a coefficient of reflectance at the corresponding wavelength, $K_{0}$ is the bias, $1 / R$ is the reflectance at the corresponding wavelength, and $n$ is the number of selected wavelengths.

As many wavelengths give redundant information, the optimum number of wavelengths is obtained when the addition of a new filter does not improve the residual standard deviation of the multiple regression.
A different approach was followed by Robert et al. (1987), who applied multivariate analysis (principal component analysis and correspondance factorial analysis). On a population of 38 milk samples from cow, goat, ewe, colostrum and mastitic animals, they found that within the limits at $2030 \mathrm{~nm}-2350 \mathrm{~nm}$, where there is no intense absorption band for water, two wavelengths at $2050 \mathrm{~nm}$ and $2180 \mathrm{~nm}$ could be assigned to milk proteins.

In a one-year study, Launay et al. (1986) have found that, amongst the 13 filters which were selected during the study by multiple regression analysis, four wavelengths were constantly used : 2180 $\mathrm{nm}, 2100 \mathrm{~nm}, 1820 \mathrm{~nm}$ and $1450 \mathrm{~nm}$.

These bands were also selected by Jeunet and Grappin (1985) in a study on individual milks. Two wavelengths, 2100 $\mathrm{nm}$ and $1820 \mathrm{~nm}$, which have negative coefficients, are not specific to protein.

Table VI gives an example of the wavelengths which have been assigned by different authors for NIR protein testing.

\section{Analysis and instrumentation}

Most of the research and practical work done on milk and milk product analysis has been carried out with the Infraalyzer instrument (Technicon, Tarry Town, NY) and in some cases with Pacific Scientific/Neotec, or Dikey-John instruments.

Sample preparation requires different approaches according to the nature of the product. For milk analysis, after homogenization to limit the light scattering effect of fat globules, the sample is placed into a temperature-controlled $\left(40 \pm 0.1^{\circ} \mathrm{C}\right)$ holder with a quartz window and a 
Table VI. Waveband assignment for NIR protein analysis of dairy products.

Affectation de longueurs d'onde proche IR pour les dosages des protéines dans les produits laitiers.

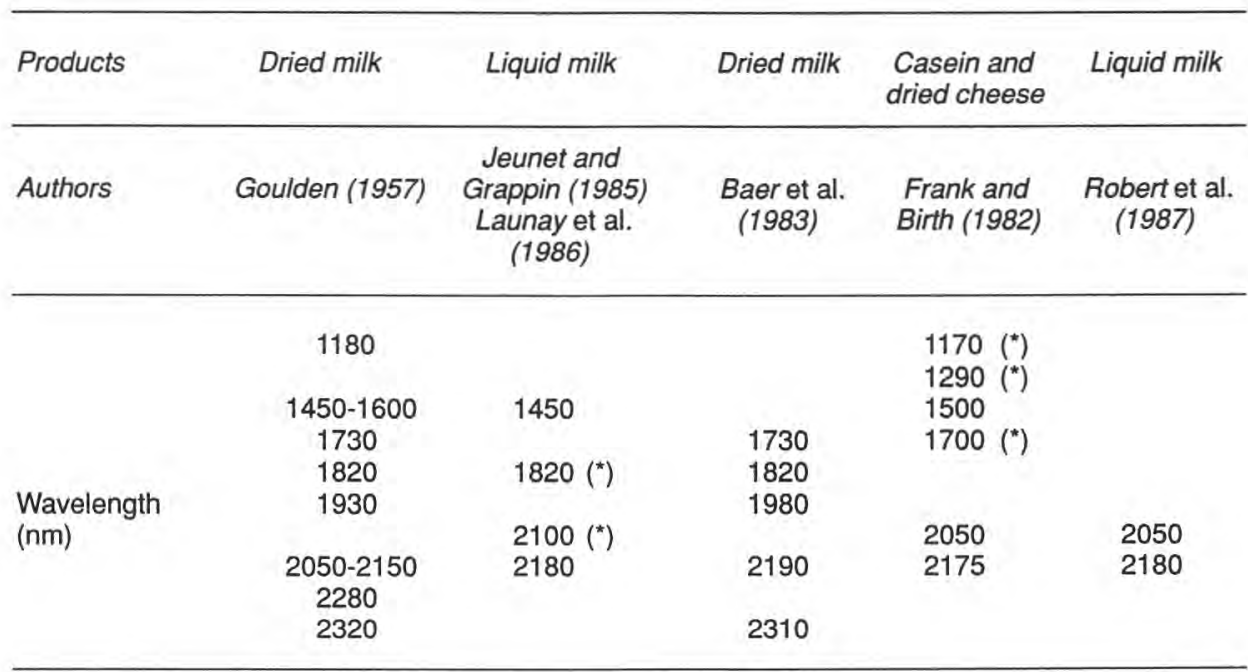

ceramic diffuse reflector. Powder samples are simply placed in a sample holder and pressed against a quartz window. Solid and pasty products, like cheese, should have a uniform surface, and are placed in an open holder.

Wavelengths can be selected either by a holographic grating for research work (e.g., Technicon Infraalyzer 500), or by narrow band interference filters in routine analysis. An intermediate solution is offered by tilting filters with a variable angle of incidence which provides some flexibility in the wavelength setting.

Reflected light originating from the irradiated sample is measured either by two lead sulphide detectors placed in an integrating sphere (Infraalyzer, Technicon) to collect as much as possible of the reflected energy, or by 4 detectors placed at an angle of $45^{\circ}$ above the sample (Pacific Scientific Instrument).

The incident or reference beam intensity is measured automatically by the detectors after rotation of the mirror for each sample measurement. A ceramic disk is used as an external reference and the reflectance values obtained at the different selected wavelenghts are stored and processed to give the component concentration.

Analytical attributes and factors affecting the accuracy of protein testing

Compared to MIR techniques, very little work has been done to thoroughly evaluate the physico-chemical and biological factors which may influence the response of NIR analysis. On individual samples of cow and goat milks, Jeunet \& Grappin (1985) have found that lipolysis does not interfere and only species significantly influences the protein results. Conversely to MIR, the accuracy SD $\left(s_{y, x}\right)$ is slightly lower (0.021 vs. 0.025$)$ when the instrument is calibrated for crude instead of true protein. Similarly, a better estimate was obtained by Baer et al. 
(1983) on non-fat dry milk when the Kjeldahl method was used on a reference, rather than the dye-binding, method. A repeatability SD of $0.023 \mathrm{~g} / 100$ $\mathrm{g}$ was reported for the Infraalyzer Dairy 400 (Jeunet \& Grappin, 1985).

\section{Application to dairy products}

NIR techniques have been evaluated for the analysis of moisture, fat and protein mainly for various milk powders (Baer et al., 1983; Frankhuisen \& Van der Veen, 1985 ) and cheese (Frankhuisen \& Van der Veen, 1985; Frank \& Birth, 1982). An example of the findings of Frankhuisen and Van der Veen (1985), concerning protein determination on milk powders and processed cheese, is given in Table VII.

\section{Amino acid composition of milk and dairy products}

Direct amino acid analysis after acid hydrolysis can give a good estimation of the protein content of any food product if the content of peptides and free amino acids is negligible. This condition can be considered as fulfilled for dairy products such as industrial caseins and caseinates, whey protein concentrates (WPG), lactalbumins, coprecipitates, and partially fulfilled for good quality milks, wheys, milk and whey powders. However, it is certainly not the best method as far as rapidity (At least $1 \mathrm{~h}$ for one sample) and accuracy are concerned. An indication of the accuracy of protein determination by this technique can be deduced from the results of inter- and intra-laboratory

Table VII. Near infra-red reflectance data for protein in some dairy products (Frankhuisen \& Van der Veen, 1985).

Données concernant le dosage des protéines dans certains produits laitiers par réflexion dans le proche IR (Frankhuisen \& Van der Veen, 1985).

\begin{tabular}{|c|c|c|c|c|c|c|c|c|}
\hline \multirow[t]{2}{*}{ Product } & \multicolumn{4}{|c|}{ Calibration } & \multicolumn{4}{|c|}{ Prediction } \\
\hline & $\mathrm{n}_{\mathrm{c}}$ & $r^{2} c$ & $S E_{\mathrm{c}}$ & range $_{\mathrm{c}}$ & $n_{p}$ & $r^{2} p$ & $S E_{\mathrm{p}}$ & range $_{\mathrm{p}}$ \\
\hline Skim milk powder & 159 & 0.97 & 0.27 & $32.9-41.2$ & 19 & 0.95 & 0.20 & $34.0-36.8$ \\
\hline $\begin{array}{l}\text { Butter milk powder } \\
\text { Skim milk powder }+\end{array}$ & 84 & 0.97 & 0.21 & $28.9-34.6$ & 20 & 0.97 & 0.21 & $29.2-34.6$ \\
\hline Buttermilk powder & 254 & 0.98 & 0.34 & $28.9-41.2$ & 20 & 0.97 & 0.46 & $30.4-40.6$ \\
\hline Denatured milk powder & 92 & 0.98 & 0.34 & $27.1-40.1$ & 20 & 0.95 & 0.42 & $28.5-39.7$ \\
\hline $\begin{array}{l}\text { Milk powder with } \\
\text { non-milk fat }\end{array}$ & 61 & 1.00 & 0.18 & $17.6-26.0$ & 10 & 0.96 & 0.25 & $18.4-25.4$ \\
\hline Processed cheese $40^{+}$ & 50 & 0.90 & 0.31 & $20.0-24.0$ & 10 & 0.89 & 0.35 & 19.9-23.7 \\
\hline
\end{tabular}

$n$ : number of samples; $r^{2}:$ coefficient of determination; SE : standard deviation of estimate.

$\mathrm{n}$, nombre d'échantillons; $\mathrm{r}^{2}$, coefficient de détermination; $S E$, écart type individual. 
analyses performed in 1983 on a single casein sample (Sarwar et al., 1983). Each laboratory analyzed the sample for dry matter and nitrogen by AOAC procedures (1975). Three hydrolyses $(6 \mathrm{~N} \mathrm{HCl}$, performic acid $+6 \mathrm{~N} \mathrm{HCl}$, and 4.2N NaOH) were carried out in duplicate for determination of stable amino acids, sulfur amino acids and tryptophan, respectively. Table VIII shows a good correlation between the nitrogen content (Kjeldahl) and the recovery of nitrogen calculated from quantitative analysis of 18 amino acids plus ammonia.

Amino acid composition of a food product is most useful for nutritionists. It can sometimes be used for the detection of adulteration, e.g., detection of added WPC in non-fat dry milk (Greenberg \& Dower, 1986). Therefore, some information will be given below on the amino acid analysis of milk and dairy products, although the methodology does not differ significantly from that used for other food products and has not changed greatly for many years.

\section{Sample preparation}

Sampling is easy for most dairy products (liquids and powders). For cheese it is convenient to freeze-dry and grind a fairly large sample in order to obtain an homogeneous powder.

Many amino acid analyzers separate the amino acids from the hydrolyzed sample by ion exchange. This technique does not necessitate very clean products. In particular, carbohydrates, even in large proportion and salts, do not cause exaggerated problems. However, the lipid content must be low. Centrifugal skimming is quite sufficient for liquid dairy products, unless milk has been homogenized. In other cases, the products must be dried and ether-extracted. The levels of salts and lipids in the samples for analysis by HPLC, after pre-column derivatization, must be negligible.

Although amino acid analysis after direct acid hydrolysis can give a fairly accurate determination of cysteine + cystine and methionine, provided all cysteine has been converted to cystine, most people prefer to transform these amino acids to more stable derivatives. For food products, this is usually achieved by performic oxidation. Part of the sample is treated with a mixture of formic acid and hydrogen peroxide at low temperature and the excess of reagents removed by evaporation. This converts cystine and

Table VIII. Recovery of nitrogen from amino acid analysis of casein carried out by 7 laboratories. Rendement en azote estimé à partir d'analyses d'acides aminés d'un échantillon de caséine.

$\begin{array}{llll}\text { Mean \% } & \text { SE } & \text { CV \% } & \text { CV \% } \\ 99.4 & 2.9 & 2.9 & 0.8\end{array}$

The protein content $(N \times 6.38$ ) of the sample was $96.7 \pm 0.8$ (mean + SEM of the 7 laboratories). SEM, standard error of the mean; SE, standard error; CV, coefficient of variation (from Sarwar et al., 1983).

La teneur en protéines $(\mathrm{N} \times 6,38$ ) de l'échantillon était de $96,7 \pm 0,8 \%$ (moyenne \pm SEM des résultats de 7 laboratoires). SEM, erreur standard de la moyenne; SE, erreur standard; CV, coefficient de variation (d'après Sarwar et al., 1983). 
cysteine into cysteic acid $(2 \mathrm{~mol} / \mathrm{mol}$ cystine) and methionine into methionine sulfone (Macdonald, 1985). As this procedure totally destroys tryptophan and partially destroys tyrosine and histidine, complete analysis of a sample requires 3 different determinations carried out on 3 hydrolysates : acid hydrolysates of the native and oxidized sample, and alkaline hydrolysate for tryptophan determination.

\section{Hydrolysis}

Food products are usually hydrolyzed at $110^{\circ} \mathrm{C}$ for 22 or $24 \mathrm{~h}$ in the presence of $6 \mathrm{~N} \mathrm{HCl}$ (for stable and sulfur amino acids) at a ratio of $\mathrm{mg}$ protein $/ \mathrm{ml}$ acid, varying between 0.4 and 4.0 (Sarwar et al., 1983). The lower ratios are used for carbohydrate-rich products. Hydrolysis is performed in tubes or flasks, either sealed, or evacuated and sealed, or evacuated, nitrogen-flushed and sealed, or under reflux. After hydrolysis, the acid is evaporated and the residue taken with $\mathrm{pH} 2.2$ citrate buffer for conventional amino acid analyzers. Filtration through a $0.45 \mu \mathrm{m}$ filter is performed. Some analysts add phenol $(50 \mu \mathrm{l}$ to $1 \mathrm{ml} / 100 \mathrm{ml})$ to the $6 \mathrm{~N} \mathrm{HCl}$ to reduce tyrosine losses. The authors do not think that this is really useful. Recently, comparison has been made between conventional acid hydrolysis, as above, and hydrolysis at $145^{\circ} \mathrm{C}$ for $4 \mathrm{~h}$ for foods and feeds (Lucas \& Sotelo, 1982; Gehrke et al., 1985). For casein, results were quite similar, with a slightly higher value for lle and a lower value for Ser and $\mathrm{Thr}$ at higher temperature. A slightly higher recovery of total amino acids was obtained at $110^{\circ} \mathrm{C}$.

In order to obtain more precise data for sensitive or more difficult-to-release amino acids (Thr, Ser, Met, Tyr; Val and lle when bonds involving these 2 residues occur), 3 hydrolysis times are selected (e.g., $22,44,88 \mathrm{~h}$ at $110^{\circ} \mathrm{C} ; 4,8$ and $12 \mathrm{~h}$ at $140^{\circ} \mathrm{C}$ ). The values for the amino acids of the former group are extrapolated to 0 time, while only the longest time is taken into account for Val and Ile.

For high sensitivities, gaseous 5.7 $\mathrm{N} / \mathrm{HCl}$ is frequently used for protein hydrolysis because of the lower background obtained and the lower amount of acid needed (Bidlingmeyer et al., 1984).

Hydrolysis for determination of Trp on an amino acid analyzer is performed at alkaline $\mathrm{pH}$ since this amino acid is destroyed during acid hydrolysis. Two methods for the determination of Trp in foods and feeds, including casein, have been published recently and the conditions for hydrolysis have been evaluated (Sato et al., 1984; Nielsen \& Hurrell, 1985). The results were similar. About 50 $\mathrm{mg}$ protein were hydrolyzed in a pyrex tube or a polypropylene liner contained in the pyrex tube (the 2 methods gave similar results) with $4 \mathrm{ml}$ of $4.2 \mathrm{~N} \mathrm{NaOH}$. The addition of partially-hydrolyzed starch $(0.17 \mathrm{~g})$ improved Trp recovery. One drop of 1- octanol (which could also be used for acid hydrolysis) prevented foaming during evacuation of the air, which could be performed with a tap-water vacuum pump. The sealed tube was placed at $110^{\circ} \mathrm{C}$ for $20 \mathrm{~h}$. After cooling, the hydrolysate was adjusted to $\mathrm{pH} 4.0$ with precooled $6 \mathrm{~N} \mathrm{HCl}$ and diluted to $20 \mathrm{ml}$ with a $\mathrm{pH} 4,2-4.3$ citrate buffer. This solution could be conserved at least 2 weeks at $5{ }^{\circ} \mathrm{C}$ without further Trp loss. Some destruction of Trp occurred during hydrolysis and this could be corrected based up on the recovery of an internal standard. In the inter- and intra-laboratory study mentioned above (Sarwar et al., 1983), it was shown that inter-laboratory variation of $\operatorname{Trp}$ (CV up to $24 \%$ ) was greater than that for all other amino acids (CV up to $10 \%)$. The values for Trp obtained by one 
laboratory using the colorimetric methods of Spies and Chamber (1948) were comparable to those using a method close to that described above.

It seems that destruction of Trp during hydrolysis with $\mathrm{HCl}$ is due to the presence of chlorine in $\mathrm{HCl}$. Hydrolysis of proteins with sulfonic acids in a reducing medium (e.g., with mercaptoethane sulfonic acid, MESA) is considered to preserve Trp from destruction. However, this procedure is little used; even under these conditions, the presence of carbohydrates affects Trp recovery. Furthermore, MESA is not volatile.

\section{Amino acid analysis}

Several new methods for amino acid determination after acid hydrolysis have appeared during the last 10 years. They present 2 main advantages over the conventional ion exchange method followed by the ninhydrin reaction : somewhat faster analyses and higher sensitivity. They include, in particular, ion exchange with new post-column derivatization reagents and reversed-phase high performance liquid chromatography (RPHPLC) with pre-column derivatization.

\section{Conventional techniques}

The conventional ion-exchange/ninhydrin procedure is by far the most employed for amino acid analysis on foods. Improvements include : automatic samplers of various types, narrow bore shorter columns (made of glass or metal) with resin particles of small diameter (for increased sensitivity and reduced buffer consumption, with concomitant higher pressure), more general use of a single column with stepwise elution ( 3 or 4 different buffers), shorter reaction times with ninhydrin at a higher temperature (e.g., $120^{\circ} \mathrm{C}$ ), sophisticated colorimeters and computerization of data collection.

lon exchange with new reagents for postcolumn derivatization

Fluorescamine, and 0 -phtaldialdehyde (OPA) +2-mercaptoethanol, react with primary amino acids only, giving fluorescent derivatives which permit high sensitivity. The latter is now the most popular reagent. It provides a hundredfold increase in sensitivity over ninhydrin. However, the detection of secondary amino acids (e.g., proline) requires an additional pump and a post-column reactor to convert the imino acids into primary amino acids with chloramine $T$ or sodium hypochlorite (Böhlen \& Schroeder, 1982).

\section{Reversed-phase HPLC (RP-HPLC)}

RP-HPLC with pre-column derivatization with OPA (Cooper et al., 1984), dansyl chloride (Wilkinson, 1978), dabsyl chloride (Vendrel \& Aviles, 1986) or phenylisothiocynate (PITC) are most popular at present in protein chemistry since they allow high sensitivity (picomolar level) and fast analyses. OPA, of course, presents here the same drawback as mentioned above : determination of secondary amines requires an oxidation step prior to reaction with OPA. Furthermore, OPA derivatives of Gly, Lys and hydroxyLys decompose easily. The reaction time must be short and accurately controlled.

The other reagents mentioned above, especially PITC which converts all amino acids, including proline, into fairly stable phenylthiocarbamyl (PTC) derivatives, are being used increasingly. For pure protein samples, separation of PTC-amino acid 
on $\mathrm{C} 18$ reversed-phase columns, $3.9 \mathrm{~mm}$ $x 15 \mathrm{~cm}$, with particles of $3 \mu \mathrm{m}$ and gradient elution, requires ca. $12 \mathrm{~min}$. The total duration of the analysis, including column washing and equilibration, requires only $\mathrm{ca}$. $20 \mathrm{~min}$ (Bidlingmeyer et al., 1984).

Quite recently, the VARIAN company (Hicksville, NY) has developed a new automatic system for amino acid analysis of protein hydrolyzates by RP-HPLC after pre-column derivatization with 9-fluorenyl methyl chloroformate (FMOC). The resulting amino acid derivatives are quite stable, unlike PTC-amino acids, and display a high fluorescence which gives extremely high sensitivity. Furthermore, it seems that derivatization is not influenced by the presence of salts in the hydrolyzate.

RP-HPLC, with direct fluorometric detection, can be used to determine tryptophan in food products after alkaline hydrolysis (Nielsen \& Hurrell, 1985).

Table IX. Precision of casein amino acid analysis carried out by seven laboratories.

Fidélité des analyses d'acides aminés effectuées par 7 laboratoires.

\begin{tabular}{|c|c|c|c|c|c|}
\hline \multirow[t]{2}{*}{ Amino acid } & \multirow{2}{*}{$\begin{array}{c}\text { Mean } \\
\text { g/16g.N }\end{array}$} & \multicolumn{3}{|c|}{ Between laboratories } & \multirow{2}{*}{$\begin{array}{c}\text { Within Laboratories } \\
\text { CV } \%\end{array}$} \\
\hline & & $S E$ & CV1\% & $c V 2 \%$ & \\
\hline Arg & 3.71 & 0.34 & 9.1 & 8.9 & 1.8 \\
\hline His & 2.97 & 0.18 & 6.0 & 5.2 & 1.6 \\
\hline lle & 5.36 & 0.26 & 4.8 & 3.8 & 1.3 \\
\hline Leu & 10.16 & 0.44 & 4.3 & 2.5 & 0.7 \\
\hline Lys & 8.44 & 0.42 & 5.0 & 4.3 & 0.6 \\
\hline Met & 3.02 & 0.13 & 4.2 & 3.1 & 0.8 \\
\hline Cys & 0.47 & 0.08 & 17.6 & 17.0 & 2.6 \\
\hline Phe & 5.47 & 0.39 & 7.1 & 5.8 & 1.5 \\
\hline Tyr & 6.04 & 0.42 & 6.9 & 5.6 & 1.2 \\
\hline Thr & 4.64 & 0.32 & 7.0 & 5.4 & 1.5 \\
\hline Trp & 1.31 & 0.19 & 14.3 & 14.2 & 1.1 \\
\hline Val & 6.85 & 0.30 & 4.4 & 2.6 & 1.4 \\
\hline Ala & 3.30 & 0.19 & 5.8 & 4.3 & 1.8 \\
\hline Asx & 7.71 & 0.31 & 4.0 & 1.9 & 0.9 \\
\hline Glx & 24.00 & 2.53 & 10.5 & 10.1 & 1.3 \\
\hline Gly & 2.00 & 0.13 & 6.4 & 5.5 & 1.3 \\
\hline Pro & 11.72 & 0.78 & 6.6 & 5.0 & 1.9 \\
\hline Ser & 6.10 & 0.22 & 3.6 & 2.1 & 1.6 \\
\hline $\mathrm{NH}_{3}$ & 1.98 & 0.19 & 9.6 & 10.7 & 5.9 \\
\hline
\end{tabular}

SE, standard error; CV, coefficient of variation; CV1, between laboratories; CV2, CVs for adjusted amino acid data (corrected to a total nitrogen recovery of $100 \%$ in each laboratory (from Sarwar et al., 1983).

SE, écart type; CV, coefficient de variation; CV1, entre laboratoires; CV2, CV pour les données ajustées (corrigées pour obtenir un rendement d'azote total de $100 \%$ dans chaque laboratoire) (d'après Sarwar et al., 1983). 
Precision of data from amino acid analysis

As an example, we will give more details of an inter-laboratory assay, already mentioned above, carried out in 1983 by seven North-American laboratories (Sarwar et al., 1983) on 7 food products (casein, egg white, beef, soy isolate, rapeseed concentrate, pea flour and wheat flour), using conventional techniques. The results for casein are shown in Table IX. The inter-laboratory variation (estimated as $\mathrm{CV}$ ) for all amino acids except cystine (17.6\%), tryptophan $(14.3 \%)$ and glutamic acid $(10.3 \%)$ was less than $10 \%(3.6-9.1 \%)$, whereas, the intra-laboratory variation for all amino acids was lower than $3 \%(0.6-2.6 \%)$. Adjustment of amino acid data to constant nitrogen recovery was reported to improve the comparability between laboratories. Application of a similar correction to the data of Table IX shows (CV1 vs. CV between laboratories) reduced interlaboratory variability for all amino acids, but not for ammonia.

\section{SEPARATE DETERMINATION OF WHOLE CASEIN, WHEY PROTEINS, $\beta$-LACTOGLOBULIN AND NPN IN MILK AND DAIRY PRODUCTS}

\section{The Aschaffenburg-Rowland proce- dure}

As early as 1938, S.J. Rowland published a method for quantitative determination of different protein fractions, whole casein, albumins, globulins and proteosepeptones in cow's milk. In 1959,
Aschaffenburg and Drewry improved this method on the basis of paper electrophoresis used as an analytical technique, and proposed a procedure to quantitate $\beta-\mathrm{Lg}$ (an albumin), residual albumins (mainly $\alpha$-La), globulins (mainly immunoglobulins) and proteose-peptones. It must be recalled that the latter constitutes a heterogeneous group of peptides or proteins which are not made insoluble by heating milk or whey at $\mathrm{pH}$ 4.6 , but are precipitated by $12 \%$ TCA. Both methods use several precipitating agents. Nitrogen is determined in milk and supernatants by the Kjeldahl technique, the protein contents being obtained by using the 6.38 coefficient (see above). The Aschaffenburg and Drewry procedure was examined (Farah, 1979) on the basis of polyacrylamide gel electrophoresis of the fractions obtained in the different steps, as far as the non-casein-proteins of milk were concerned. This study indicated that casein precipitation with $\mathrm{Na}$ acetate and acetic acid, as performed by Aschaffenburg and Drewry, indeed gives a supernatant devoid of caseins. On the other hand, it is well known that whole casein, so prepared, provided it is washed at $\mathrm{pH} 4.7$, is only slightly contaminated by whey proteins $(5 \%)$. But this is not true for human casein (Brignon et al., 1984). This study also showed that Aschaffenburg and Drewry's fraction " $\beta$ - $\mathrm{Lg}$ plus NPN", which remains soluble at $\mathrm{pH}$ 2.0 in the presence of $20 \mathrm{~g} \mathrm{Na}_{2} \mathrm{SO}_{4} / 100$ $\mathrm{ml}$ milk, indeed contains $\beta$ - $\mathrm{Lg}$ as the only protein. As it has been known for a long time that the NPN fraction contains most if not all the low molecular weight nitrogenous molecules present in milk (amino acids, small peptides, nucleotides, vitamins, urea, creatinine, ammonia etc.), the following fractions can be safely determined according to Aschaffenburg and Drewry (1959) with the new recently determined conversion factors (Karman \& 
Van Boekel, 1986; Van Boekel \& Ribadeau-Dumas, 1987) :

- protein content of milk : (nitrogen content) $\times 6.35$

- content of milk non-protein nitrogenous compounds : (nitrogen content of the $12 \%$ TCA supernatant) $\times 3.60$

- whole casein content of milk : (nitrogen of milk minus that of the $\mathrm{pH} 4.7$ supernatant) $\times 6.36$

- whey protein content of milk : (nitrogen content of the above supernatant minus that of the $12 \%$ TCA supernatant of milk) $\times 6.28$

- $\beta$ - $\mathrm{Lg}$ content of milk : (nitogen content of the $\mathrm{Na}_{2} \mathrm{SO}_{4}$ supernatant, $\mathrm{pH} 2$, of milk minus that of the $12 \%$ TCA supernatant) $x$ 6.29.

However, according to the data given by Farah (1979), the other protein fractions, which could be determined by the Aschaffenburg-Drewry method, appear to be meaningless.

The detailed procedure has been clearly described by Aschaffenburg and Drewry (1959), taking into account, for the calculations, the dilutions, the volume of the precipitates and the change of volume caused by salt addition.

Note that Kjeldahl factors, mentioned above, give protein contents which include bound phosphate and carbohydrates. Therefore, the figures obtained should be slightly higher than those deduced from amino acid analysis (except for $\beta-\mathrm{Lg}$, which contains neither phosphate nor carbohydrate).

\section{Determination of casein and whey proteins by indirect methods}

Because in milk, both whole casein and serum proteins behave similarly in presence of dyes or IR radiation, the direct estimation of the concentration of each of these two groups of components is not feasible. For their determination, separation of the caseins, either by acid precipitation or by rennet coagulation, followed by at least two measurements, is required.

\section{Dye binding methods}

- McGann et al. (1972) developed a procedure for measuring casein in milk after acid precipitation (acetic acid-sodium acetate) of the non-casein fraction, and separation by filtration. Determination involves three measurements : milk, milk $+1 \mathrm{ml}$ of water, and milk $+1 \mathrm{ml}$ of the non-casein filtrate. A correction factor of 0.04 has to be used to get an accurate casein reading when using a Pro-milk instrument calibrated for crude milk protein analysis. A standard deviation of $0.022 \mathrm{~g} / \mathrm{mg}$ was obtained with bulk milk samples by comparison with the Kjeldahl method.

- A different procedure using rennet clotting has been developed by several authors (Kristoffersen et al., 1974; Mickelsen \& Shukri, 1975). This method involves initial separation of the rennet coagulable casein fraction by filtration or centrifugation after a small amount of rennet has been added to the milk, followed by analysis on milk and whey. Whey protein content can be measured directly using the same procedure and same calibration as for milk protein analysis. The rennet casein content is then obtained by subtracting the whey protein content from the milk protein content; a correction factor might be necessary to obtain the exact rennet casein value (Kristoffersen et al., 1974). In their experimental work on goat milk (Jeunet \& Grappin, 1985), and in other 
unpublished experiments, Jeunet and Grappin have used a slightly different procedure. The whey protein content is assayed by using a test sample volume equivalent to three times the volume used for milk testing in order to obtain a protein concentration in the reaction mixture that is similar to that of milk.

For cows' milk, the whey true protein content (WP) is obtained using the formula : WP $=0.36 \times(A B)-2.10$, where $(A B)$ is the Amido Black reading (in $\mathrm{g} / \mathrm{kg}$ ) given by the instrument calibrated for the measurement of true protein in milk. To obtain the correct whey protein content in milk, the test result on whey has to be multiplied by a factor close to 0.95 (Grappin \& Jeunet, 1979), which takes into account the volume of the precipitate obtained during clotting. The rennet casein content of milk is then obtained by subtracting the corrected whey true protein content from the true protein content of milk.

\section{Infra-red methods}

For both MIR and NIR techniques, only the procedure measuring rennet casein can be used because with the acid precipitation technique the presence of a large amount of acid in the non-casein filtrate interferes at the protein wavelength(s).

To measure the protein content in whey, the IR instrument has to be calibrated by reference to the Kjeldahl method. If the $6.46 \mu \mathrm{m}$ wavelength in MIR is suitable for both milk and whey analysis, a specific calibration involving different wavelengths and different coefficients may be necessary with the NIR technique (Jeunet \& Grappin, 1985).

In each case, the rennet casein content is obtained by subtracting the whey protein content from the milk protein content.

\section{Analytical performances}

For the Amido Black method and IR techniques, the repeatability standard deviation for the measurement of protein in whey is close to the values found for milk testing. Because of the lower protein concentration in whey, one might expect a higher coefficient of variation. Table $X$ shows examples of the accuracy of the measurement of whey proteins and rennet casein by Amido Black and IR instruments, using the Kjeldahl method as a reference.

The excellent accuracy of the IR methods for measuring rennet casein will be appreciated when compared to the other methods. One reason might be that most of the non-protein components which interfere at the protein wavelength(s), for both milk and whey analysis, are in the soluble phase (see Fig. 7 for MIR) and their influence is eliminated by subtracting the whey protein test result from the milk protein test result.

\section{SEPARATE DETERMINATION AND CHARACTERIZATION OF INDIVIDUAL PROTEINS IN MILK AND DAIRY PRODUCTS}

Since the technological and nutritional behaviour of a protein is unique, an increasing number of people would like to obtain quantitative and qualitative information (e.g., the content in the various proteins, genetic variants) on some or each main protein species in food products. Such information can now 
Table X. Accuracy standard deviation ( $s_{y, x}$ in $g / 100 \mathrm{~g}$ ) of the determination of milk true protein, whey true protein and rennet casein in milk using the Amido Black, Milko-Scan and Infraalyzer techniques. Déviation standard $\left(s_{y, x}\right.$ en $\left.g / 100 \mathrm{~g}\right)$ du dosage des protéines vraies du lait, des protéines vraies du lactosérum et de la caséine présure dans le lait en utilisant le Noir Amido, le Milko-Scan et I'Infraalyzer.

\begin{tabular}{llccc}
\hline Reference & Methods & Milk & Whey & Difference milk-whey \\
& & True protein & True protein & Rennet casein \\
\hline 81 individual & Amido Black & 0.040 & 0.018 & 0.040 \\
goat milks ${ }^{1}$ & Milko-Scan 300 & 0.035 & 0.026 & 0.025 \\
40 individual & Amido Black & 0.035 & 0.024 & 0.028 \\
cow milks ${ }^{2}$ & Milko-Scan 104 & 0.044 & 0.032 & 0.018 \\
20 individual & Amido Black & 0.043 & 0.015 & 0.059 \\
cow milks ${ }^{3}$ & Milko-Scan 104 & 0.035 & 0.026 & 0.024 \\
& Infraalyzer 400 & 0.025 & 0.023 & 0.018 \\
& & & & \\
\hline
\end{tabular}

1 Grappin \& Jeunet, 1979

2 Michalak \& Oczkowicz, 1975

3 Jeunet \& Grappin, 1985

be obtained, at least in some laboratories, on raw milk and sometimes on many simple dairy products, such as pasteurized and sterilized milk, caseins, caseinates, whey and WPC. The situation is more complex in fermented dairy products (cheese, yoghurt) in which partial degradation of proteins has occurred. However, information on the occurrence and amount of a milk protein can provide useful information on technological treatments and fraudulent adulterations (e.g., mixtures of milks of different species).

The main techniques that have been employed during the last 10 years to characterize and determine the main proteins in milk and some dairy products are electrophoresis, liquid column chromatography and immunochemical methods. For the milk enzymes of interest, determinations are usually made by activity measurements.

\section{Electrophoresis}

\section{Electrophoresis without SDS}

This is the most widely used procedure for phenotyping individual cows, and the most rapid one for determining the main proteins in raw milk.

\section{Dairy species phenotyping}

Electrophoresis has been used to phenotype milk proteins from the cow, water buffalo, goat and ewe. We will only consider here what has been done on bovine milk.

Electrophoresis is performed in either starch, polyacrylamide, or polyacrylamideagarose. The presence of urea and a reducing agent (2-mercaptoethanol or dithiothreitol) is required for satisfactory 
separation of caseins. The former reagent allows dissociation of intermolecular aggregates while the latter splits intermolecular disulfide bridges in $\alpha_{\mathrm{S} 2^{-}}$and $\kappa$ Cns.

Genetic variants of a protein arise from heritable modifications involving the gene coding for it. As these are rare events, they lead only to a few modifications within a species. The most common modifications are point mutations : a single base in the gene DNA is replaced by another. This may lead to the substitution of one amino acid residue by another in the peptide chain. This substitution can be detected by electrophoresis if it involves at least one amino acid carrying an electric charge, that is, in milk proteins, Asp, Glu, P-Ser, P-Thr, Arg, Lys or His. However, Asp and Glu take a negative charge only above the $\mathrm{pK}$ of their lateral carboxyl groups, i.e., above $\mathrm{pH} 3$ to 4 , while the positive charge of His appears below the $p K$ of the imidazole ring $\mathrm{NH}$ group, i.e., below $\mathrm{pH} 6$. $\mathrm{P}$-Ser and P-Thr are negatively charged and Arg and Lys are positively charged throughout the entire $\mathrm{pH}$ range, which can be used in electrophoresis. In other words, substitutions of P-Ser, P-Thr, Arg and Lys by a neutral amino acid can be detected both at alkaline and acid $\mathrm{pH}$ values (usually $\mathrm{pH} 8.6$ and 3 ) on electrophoresis, while and acid $\mathrm{pH}$ must be used when $H$ is is involved. Unfortunately, only $c a$. one third of the mutations involves charged amino acids and there is no simple method for detecting the other two-thirds. Studies on genetic variants of milk proteins have received renewed interest during the last 10 years; indeed, correlations have been found between the occurrence of certain variants and some interesting technological features of milk.

Among the common variants of milk proteins, $\alpha$-La $B, \beta-\operatorname{Lg} A$ and $B, \alpha_{s 1}-C n B$ and $C, \alpha_{s 2}-C n A, \beta-C n A^{1}, A^{2}$ and $B$, only $\beta$-Cns $A^{1}$ and $A^{2}$, which differ by $a$ histidine residue, have to be differentiated by electrophoresis at acid $\mathrm{pH}$.

Methods have been published for the simultaneous characterization of the variants of the main whey proteins ( $\alpha$-La, $\beta-L g)$ and caseins $\left(\alpha_{s 1}, \alpha_{s 2}, \beta\right.$ and $\left.\kappa\right)$ by electrophoresis at alkaline $\mathrm{pH}$. Unfortunately, this does not allow differentiation of $\beta-C n A^{1}$ and $A^{2}$. Furthermore, the electrophoretic patterns so obtained are not easily interpretable. Nowadays, most people perform 3 different electrophoretic separations for each sample to be tested: at alkaline and acid $\mathrm{pH}$ values on milk or $\mathrm{pH}$ 4.7-precipitated casein in the presence of urea and reducing agent, for typing caseins; at alkaline $\mathrm{pH}$ on milk or acid whey, without the latter two reagents, for typing whey proteins.

Electrophoresis is usually run for $4 \mathrm{~h}$ (or overnight) at alkaline $\mathrm{pH}$ and overnight at acid $\mathrm{pH}$. A large number of samples can be analyzed simultaneously. Staining is performed using Coomassie Blue ( $R$ or G) or Amido Black.

Information concerning the chromatographic procedures that can be used for phenotyping or quantifying bovine milk proteins, the frequencies of the various alleles of each main milk protein in different breeds and the association of genetic variants with some milk characteristics can be found in the publications by McKenzie (1971), Swaisgood (1982), Grosclaude (1979, 1988), Ng-Kwai-Hang et al. (1984, 1987), Ng-Kwai-Hang and Kroeker (1984), McLean et al. (1982, 1984) and Gripon et al. (1975).

\section{Quantitation of milk proteins}

This has mainly been carried out on individual fresh bovine milk for genetic 
purposes. The techniques are identical to those mentioned above. However, as densitometric scanning is required, acrylamide or acrylamide-agarose gels are preferred to starch gels, which are not transparent. Separate electrophoresis at alkaline $\mathrm{pH}$ are carried out on $\mathrm{pH}$ 4.7precipitated casein (with urea and reducing agent) and whey. When vertical slab gels are used, para-к- $\mathrm{n}$, which often occurs in milk in small amounts, cannot be determined since it migrates upwards at alkaline $\mathrm{pH}$. Amido Black $10 \mathrm{~B}$ or Coomassie Blue $\mathrm{G} 250$ are used to stain proteins. For determination of the absolute amount of proteins following scanning densitometry, which gives areas proportional to the amounts, it is necessary to know their dye binding capacities. These are : $375,295,315$, $425,440,430$ and $320 \mathrm{mg}$ dye/g protein with Amido Black for $\alpha_{s^{-}}, \beta-, \kappa-C n s, \beta-L g$, $\alpha-L a, \quad B S A$ and Igs, respectively (Tarassuk et al., 1967); $\alpha_{\mathrm{S}}-\mathrm{Cn}$ being the sum $\alpha_{\mathrm{s} 1}+\alpha_{\mathrm{s} 2}$. With Coomassie Blue G 250 , the following relative figures have been determined : $\alpha_{s 1} B=1.00 ; \alpha_{s 1} C$, $0.94 ; \alpha_{s 2}, 0.98 ; \beta A^{1}, 0.69 ; \beta A^{2}, 0.66 ; \beta B$, 0.71 ; para- $\kappa, 0.76$ (Mc Lean et al., 1982, 1984). In the latter case, whey proteins were determined by radial immunodiffusion. Furthermore, as horizontal gels were used, the concentrations of $\alpha_{\mathrm{s} 1^{-}}$, $\alpha_{\mathrm{s2}^{-}}$and $\beta$-Cns were determined in samples not treated with chymosin (CV = $5 \%$ expressed as percent of total casein) and those of $\gamma$ and $\kappa$-Cns were determined in chymosin-treated samples (CV $=14 \%)$.

On electrophoresis, $\alpha_{\mathrm{s} 1^{-}}, \alpha_{\mathrm{s} 2}$ and $\kappa-$ Cns give 2, 4, 1 major and several minor bands, respectively. The several $\mathrm{k}-\mathrm{Cn}$ bands are transformed by chymosin into one (or two) para- $\kappa-\mathrm{Cn}$ bands. When $\kappa-$ $\mathrm{Cn}$ is determined directly on vertical gels (without chymosin treatment), only the major band is taken into consideration.

\section{Electrophoresis in the presence of SDS}

SDS binds strongly to proteins, mainly through hydrophobic interactions. The amount, which is fixed, is approximately proportional to the weight of protein : $\mathrm{ca}$. $1.4 \mathrm{~g} \mathrm{SDS} / \mathrm{g}$ protein (Reynolds \& Tanford, 1970). Thus, any protein molecule will bind a large number of SDS molecules, each of which carries a negative charge. The indigenous net charge of the protein at any $\mathrm{pH}$ is thus made negligible. Any protein should migrate at the same velocity towards the anode in free flow electrophoresis in the presence of SDS. However, in zone electrophoresis, in particular in acrylamide gels, the bigger a protein, the lower its electrophoretic mobility due to the sieving action of the gel.

This technique is widely used to determine the $M_{\mathrm{r}}$ of proteins as the logarithm of $M_{r}$ is proportional to the distance of migration (Shapiro et al., 1967). $M_{\mathrm{r}}$ is easily obtained by running an electrophoregram of the protein(s) of interest and a mixture of proteins of known molecular weights, and by plotting $\log M_{r}$ versus distance of migration.

By using polyacrylamide gels with an acrylamide concentration increasing linearly from cathode to anode, it is possible to cover a wider range of $M_{r} s$ than with homogeneous gels. In this case, a linear relationship exists between $\log M_{r}$ and $\log$ (distance of migration) (Rodbard et al., 1971).

Contrary to what would be expected from their molecular weights, the 4 bovine caseins can be separated by SDSPAGE in the presence of a reducing agent (Green \& Pastewka, 1976; Creamer \& Richardson, 1984; Trieu-Cuot, 1981; Miranda, 1983), giving 4 distinct bands corresponding, in the order of increasing mobility, to : $\alpha_{\mathrm{s} 1^{-}}, \alpha_{\mathrm{s} 2^{-}}, \beta$ - and $\kappa$-Cns. 
Furthermore, the following other proteins, all of which have mobilities higher than those of the caseins, can also be distinguished by SDS-PAGE of milk : $\gamma_{1}-\mathrm{Cn}, \beta-\mathrm{Lg}, \alpha$-La + para-k-Cn, $\gamma 2-+\gamma 3-$ Cns in the order of increasing mobilities (Miranda, 1983). To our knowledge, this method, which is widely used in our laboratory for other purposes, has never been employed for quantitative determination of milk proteins. However, it could give, by scanning densitometry of a single gel, the absolute amounts of the main proteins present in individual or bulk milks.

\section{Isoelectric focusing (IEF)}

Although IEF was applied to casein fractions in 1969, the first clear identification of the various protein components which can be separated from whole casein by this technique, appeared in 1981 in a paper by Trieu-Cuot \& Gripon (1981). IEF was performed in 1-mm thick polyacrylamide gels containing ampholytes, $7 \mathrm{M}$ urea and $0.1 \%$ 2-mercaptoethanol. The following components were identified, in order of decreasing isoelectric $\mathrm{pHs}: \boldsymbol{\gamma}-\mathrm{Cns}$ (the 3 known components), $\kappa-\mathrm{Cn}$ ( 2 components), $\alpha_{\mathrm{s} 2-}$ $\mathrm{Cn}$ (the 4 known components), $\beta-\mathrm{Cn}$ and $\alpha_{\mathrm{s} 1}-\mathrm{Cn}$ (several components, including $\left.\alpha_{s 0}\right)$. IEF was used recently for phenotyping, in a single run, all milk proteins in ultrathin-layer polyacrylamide gels (Seibert et al., 1985). The following variants could be detected : $\alpha_{\mathrm{s} 1}$-Cns A, B, C; $\alpha_{\mathrm{s} 2^{-}}$ Cn $B ; \beta-C n s A^{1}, A^{2}, A^{3}, B, C ; \kappa-C n, A, B$, $\alpha$-La $B$; and, $\beta$-Lgs A, B, C. Table XI gives the isoeletric $\mathrm{pHs}$ that have been measured (Trieu-Cuot \& Gripon, 1981; Seibert et al., 1985).

The method described by Seibert et al. appears quite promising. It is particularly short : 15 min prefocusing and
$30 \mathrm{~min}$ focusing. A number of samples can be treated simultaneously. Prior to focusing, defatted milk was diluted $1: 11$ with a solution of $8 \mathrm{M}$ urea in distilled water containing $3 \%$ (v/v) 2-mercaptoethanol.

\section{Two-dimensional electrophoresis}

This technique is especially useful for qualitatively analyzing complex mixtures of proteins, by taking advantage of two different criteria simultaneously, generally isoelectric $\mathrm{pH}$ (or electrophoretic mobility) and $M_{r}$. It was applied to caseins by Trieu-Cuot \& Gripon in 1981. They used isolectric focusing ( $\mathrm{pH} 4$ to 9 ) in the first dimension and PAGE (from $1 \%$ to $28 \%$ acrylamide) in the presence of $0.1 \%$ SDS and $4.9 \mathrm{M}$ urea. Good resolution was obtained of $\alpha_{s 1}-$ Cn (2 fractions with same $\left.M_{\mathrm{r}} \mathrm{s}\right), \alpha_{\mathrm{s} 2}-\mathrm{Cn}$ (several fractions with same $M_{r} s$ ), $\beta-C n, k-C n$ ( 3 fractions with the same $\left.M_{\mathrm{r}} \mathrm{s}\right), \gamma 2$ and $\gamma 3$ fractions (the same $\left.M_{\mathrm{r}} \mathrm{s}\right)$ and $\gamma 1$.

In 1983, Miranda showed that twodimensional electrophoresis of milk proteins (fraction insoluble in 12\% TCA) separated the caseins mentioned above, as well as para- $\kappa-\mathrm{Cn}, \beta-\mathrm{Lg}$ and $\alpha-\mathrm{La}$. UHT milk gave a similar pattern. However, $\kappa-\mathrm{Cn}, \alpha$ - La and $\beta$ - $\mathrm{Lg}$ produced fainter spots. With sterilized milk, only $\alpha_{s 1^{-}}$and $\beta$-Cns remained visible. A high $M_{r}$ component, which could not penetrate the gel, appeared. It may correspond to a polymer produced by Maillard reaction between milk proteins and lactose (Andrews \& Cheeseman, 1971).

The main interest of two-dimensional electrophoresis is its high resolution which can be exploited to study complex hydrolysates of milk proteins. Thus, Trieu-Cuot \& Gripon (1981); Miranda (1983), used it to follow cheese ripening, 
Table XI. pHi values of milk proteins from isoelectric focusing.

Valeurs des points isoélectriques des protéines du lait obtenues par focalisation isoélectrique.

Protein

Interval at probability level

of $5 \%$, after correctiona

Seibert et al. (1985)

Trieu-Cuot and Gripon (1981)

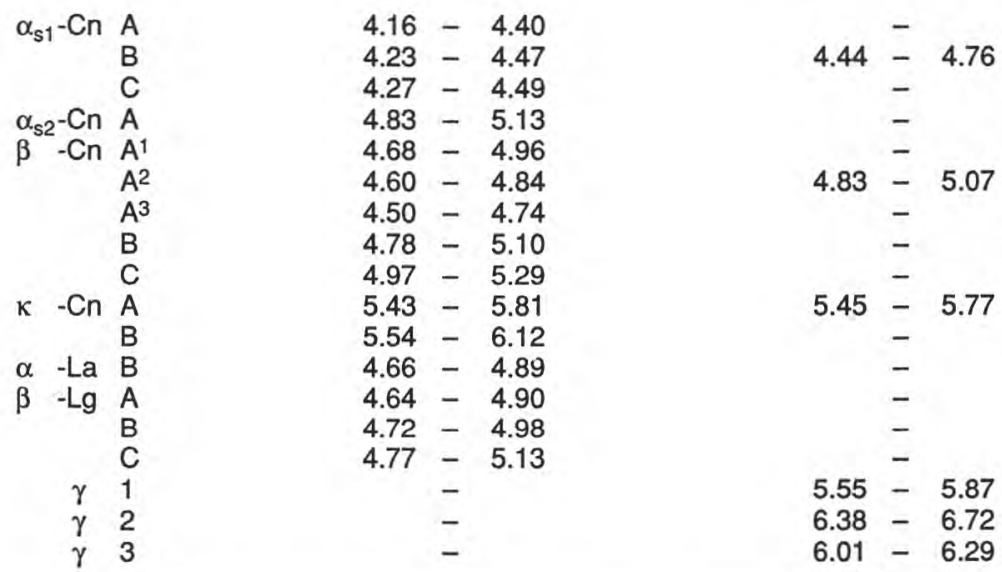

a, correction for $\mathrm{pH}$ shift, due to urea, was made by subtracting the $\mathrm{pH}$ difference between an ampholyte solution and the same solution plus urea, ampholytes and urea being at the same concentration as in the gel.

a, correction pour le déplacement $\mathrm{du} \mathrm{pH}$ du à l'urée. Obtenue en soustrayant la différence de pH observée entre une solution d'ampholytes et la même solution additionnée d'urée, les ampholytes et l'urée étant à la même concentration que dans le gel.

and proteolytic breakdown of milk proteins during in vivo digestion, respectively.

\section{Column chromatography}

A review dealing with the chromatographic separation of milk proteins was published in 1971 by Yaguchi and Rose. At that time, only gel filtration and ion exchange were used in open columns. Nowadays, the tremendous advances in the technology of chromatographic stationary phases and equipment have led to an almost complete superseding of open columns by HPLC columns in which stationary phases composed of spherical, small-diameter particles are used at high pressure. Fast analyses at high sensitivity can thus be obtained. This is especially interesting in the analytical field. Furthermore, new procedures, such as reversedphase chromatography and chromatofocusing have appeared.

\section{Gel Filtration}

Direct analysis of skim-milk in phosphate buffer, $\mathrm{pH} 7.0$ at $4{ }^{\circ} \mathrm{C}$ on Sephadex $\mathrm{G}$ 
200 , separated caseins into 3 fractions ( $\kappa$ $\left.+\alpha_{s}+\beta, \alpha_{s}>\beta, \beta>\alpha_{s}\right) . \beta-\operatorname{Lg}$ and $\alpha$-La followed caseins in this order. Resolution was poor (Yagushi \& Tarassuk, 1967). Several attempts at separating skim milk proteins on high performance gel filtration columns have been made (Dimenna \& Segall, 1981; Shimazaki \& Sukegawa, 1982; Gupta, 1983). It seems to us that the best results for analytical purposes were obtained by Dimenna \& Segall (1981) using a tandem of 2 TSK columns from Toyo-Soda (Biorad, Richmond, CA) (Fig. 8). Gupta (1983) studied the fractionation of skim milk proteins on a TSK 3000 SW column, either in their native state, or after denaturation by SDS and 2-mercaptoethanol. According to this author, the first procedure allowed

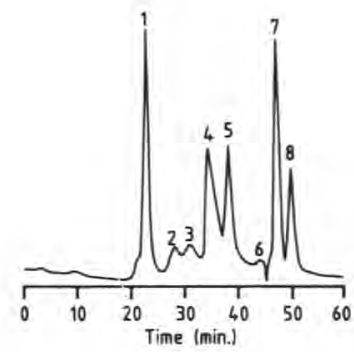

Fig. 8. FPLC Gel filtration of skim milk on a tandem of $7.5 \times 300 \mathrm{~mm}$ Toyo-Soda $3000 \mathrm{SW}$ plus 2000 SW columns (Dimenna \& Segall, 1981).

$10 \mu \mathrm{l}$ injected; flow rate : $0.5 \mathrm{ml} / \mathrm{min}$; eluent : $0.05 \mathrm{M}$ phosphate buffer $\mathrm{pH} 6.80$ containing 0.1 $\mathrm{M} \mathrm{Na}_{2} \mathrm{SO}_{4}$; detection at $280 \mathrm{~nm}$.

1, Cns; 2 , IgGs; 3 , BSA; 4, $\beta$-Lgs; $5, \alpha$-La. No protein in 6-8.

Gel filtration (FPLC) de lait écrémé sur 2 colonnes Toyo-Soda de 7,5 $30300 \mathrm{~mm}, 3000$ SW et 2000 SW, en série (Dimenna \& Segall, 1981).

Volume injecté : $10 \mu \mathrm{l}$; débit : $0,5 \mathrm{ml} / \mathrm{min}$; éluent : tampon phosphate $0,05 \mathrm{M}, \mathrm{pH} 6,80$, contenant $\mathrm{Na}_{2} \mathrm{SO}_{4} \mathrm{O}, 1 \mathrm{M}$; détection à $280 \mathrm{~nm}$. 1, Cns; 2, IgGs; 3, BSA; 4, $\beta$-Lgs; $5, \alpha$-La. Pas de protéines dans les fractions 6-8. quantitation of the individual whey proteins within $10 \%$. A method of calculation was given for determining, by using the second procedure, the concentration of individual proteins in a mixture of casein and whey proteins.

Gel permeation is not suitable for analyzing skim milk and whole casein. In milk, caseins occur as micelles of various sizes together with some soluble casein (aggregates). Removal of calcium dissociates the micelles into large polydisperse aggregates containing various proportions of the different caseins. Finally, in the presence of urea and reducing agent, the monomeric caseins are obtained. Their $M_{\mathrm{r}} \mathrm{s}$ are too close to each other and too close to those of some of the whey proteins $(\beta-\mathrm{Lg}$, lgs light chains) for a satisfactory separation in gel permeation.

However, whey proteins are quite well separated by such a system, which allows their quantitation (Dimenna \& Segall, 1981; Shimazaki \& Sukegawa, 1982; Gupta, 1983; Humphrey, 1984; Andrews et al., 1985). In a study by Andrews et al., (1985) using a Superose 12 column (Pharmacia, Uppsala, Sweden), a satisfactory separation of the main whey proteins and orotic acid was obtained (Fig. 9). Area measurements led to concentration values of lgs $=0.51, B S A=$ $0.56, \beta-\operatorname{Lg}(B+A)=3.25, \alpha-\operatorname{La}=1.25$ $\mathrm{mg} / \mathrm{ml}$, in good agreement with literature values.

\section{lon exchange}

No satisfactory result has been obtained for fractionating skim milk proteins directly by ion exchange. However, both whole casein and whey proteins can be separated in conditions suitable for quantitative analyses. 


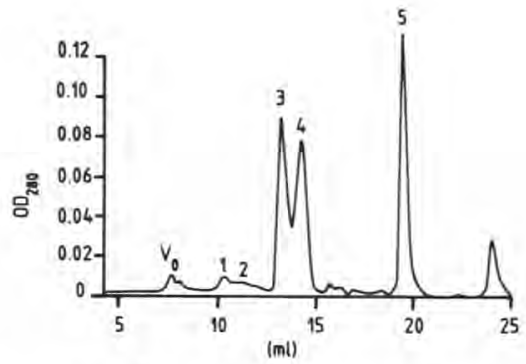

Fig. 9. FPLC separation of whey proteins by gel filtration on a Superose 12 column (Andrews et al., 1985).

$50 \mu \mathrm{l}$ fresh acid whey injected; flow rate : 0.5 $\mathrm{ml} / \mathrm{min}$; eluent : $0.1 \mathrm{M}$ Tris- $\mathrm{HCl}$ buffer $\mathrm{pH} 7.0$ containing $0.5 \mathrm{M} \mathrm{NaCl}$ and $10 \mathrm{mM} \mathrm{NaN}_{3} .1$, Igs; 2 , BSA; 3 , $\beta$-Lgs; 4 , $\alpha$-La; 5 , orotic acid.

$\mathrm{Gel}$ filtration (FPLC) des protéines du lactosérum sur une colonne Superose 12 (Andrews et al., 1985).

Volume injecté : $50 \mu \mathrm{l}$ de lactosérum acide frais; débit : 0,5 ml/min; éluent : tampon Tris- $\mathrm{HCl}, 0,1 \mathrm{M} \mathrm{pH} 7,0$, contenant $\mathrm{NaCl} 0,5$ $M$ et $\mathrm{NaN}_{3} 10$ mM. 1, Igs; $2, B S A ; 3, \beta$-Lgs; 4 , $\alpha-L a ; 5$, acide orotique.

With open columns, caseins were separated on anion or cation exchangers (e.g., Mercier et al., 1968; Annan \& Manson, 1969) in the presence of urea and 2-mercaptoethanol. Anion exchangers are now by far the most frequently employed. Using DEAE-cellulose, a procedure was developed by Davies and Law (1977a) for quantitative analysis of the components of reduced and alkylated (iodoacetamide) whole casein. Satisfactory separation of $\gamma 2-, \gamma 1-, \gamma 3-, \kappa-, \beta$-, $\alpha_{\mathrm{s} 2^{-}}$and $\alpha_{\mathrm{s} 1}-\mathrm{Cns}$, eluted in that order by a $\mathrm{NaCl}$ gradient in Tris buffer, $\mathrm{pH}$ 8.6, containing $6 \mathrm{M}$ urea, was obtained. The protein content of each casein fraction was determined by a micro-biuret method, from the specific extinction coefficients of the corresponding copperprotein complexes. This procedure was used to determine the proteins mentioned above in whole casein from a number of individual, herd bulk and creamery milks
(Davies \& Law, 1977a, 1977b, 1980). The agreement between duplicate analyses and the average recovery (95.66 $\pm 1.3 \%$ ) were both satisfactory, but long runs (ca. 20 h) were necessary. Quite similar fractionations were recently obtained from reduced non-alkylated whole casein by high performance anion exchange on DEAE-TSK-5PW (Toyo-Soda, Japan) or Mono Q HR 5/5 (Pharmacia, Uppsala, Sweden) columns, under conditions similar to those mentioned above, but with the addition of a reducing agent to buffers, with elution times of $\mathrm{ca} .1 \mathrm{~h}$ (Humphrey \& Newsome, 1984; Visser et al., 1986; Guillou et al., 1987). Limited quantitative data are given in a paper by Humphrey and Newsome (1984); in the sample of casein analyzed, $\alpha_{\mathrm{s} 1}$-casein constituted $39 \%(w / w)$ and $\beta$-casein $36 \%(w / w)$ of the total proteins. Protein recovery determined for these two caseins was $>96 \%$. Fig. 10 shows the separation of an individual casein sample on a mono $Q$ column in the presence of urea and reducing agent. In this case, some genetic variants were separated (Guillou et al., 1987).

Although it has been known for a long time that satisfactory separation of whey proteins can be obtained on DEAEcellulose, no quantitative data are available on the protein composition of whey deduced from chromatography on open anion exchange columns. By anion exchange HPLC, with Toyo-Soda DEAE5PW or Pharmacia Mono Q HR, 5/5 columns good separations were obtained for the main whey proteins (Humphrey, 1984; Andrews et al., 1985; Humphrey \& Newsome, 1984; Manji et al., 1985) (Fig. 11). Concentrations determined from chromatography of a sample of acid whey on mono $Q$ column were $2.1,1.3$ and 0.8 $\mathrm{mg} / \mathrm{ml}$ for $\beta-\mathrm{Lg} A, \beta-\mathrm{Lg} B$ and $\alpha-\mathrm{La}$, respectively (Humphrey \& Newsome, 1984). 
Chromatography on hydroxyapatite (HA)

This stationary phase is especially interesting for fractionating caseins since

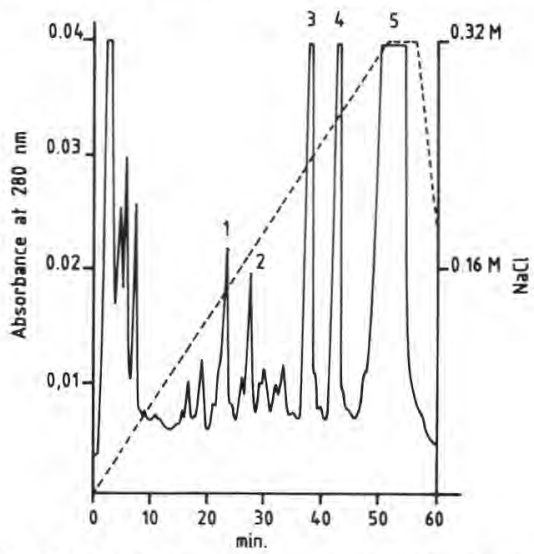

Fig. 10. FPLC separation of individual whole casein ( $\kappa A / B, \beta C / A^{1}, \alpha_{s 2} A, \alpha_{s 1} B$ ) by anion exchange on a Mono $Q$ column (Guillou et al., 1987).

Casein sample in $5.10^{-3} \mathrm{M}$ Tris- $\mathrm{HCl}, 4.5 \mathrm{M}$ urea buffer $\mathrm{pH} 8.0,8.10^{-4} \mathrm{M}$ dithiothreitol; flow rate : $1 \mathrm{ml} / \mathrm{min} ; 40^{\circ} \mathrm{C}$; elution with the same solution as above with a $0-0.32 \mathrm{M} \mathrm{NaCl}$ gradient.

1, кO-Cn B; 2, кO-Cn A; 3, $\beta-C n C ; 4, \beta-C n A^{1}$; $5, \alpha_{s 2^{-}}, \alpha_{s 1^{-}}, \alpha_{s 0^{-}}$Cns. Overloading allows clear visualisation of the $\kappa-C n$ fractions, but decreases resolution between $\alpha_{s 2}$ - (left part of the main peak), $\alpha_{\mathrm{s} 1^{-}}$(main peak), $\alpha_{\mathrm{s0}}$ (right part of main peak) Cns.

Séparation (FPLC) d'une caséine entière individuelle ( $\kappa A / B, \beta C / A^{1}, \alpha_{s 2} A, \alpha_{s 1} B$ ) par échange d'anions sur colonne Mono $Q$ (Guillou et al., 1987).

Echantillon de caséine dissous dans du tampon Tris- $\mathrm{HCl} 5.10^{-3} \mathrm{M}$, urée $4,5 \mathrm{M}, \mathrm{pH}$ 8,0 , dithiothréitol $8.10^{-4} \mathrm{M}$; débit : $1 \mathrm{ml} / \mathrm{min}$; $40{ }^{\circ} \mathrm{C}$; élution avec la même solution que précédemment avec un gradient de 0 à 0,32 $\mathrm{M}$ en $\mathrm{NaCl}$.

1 , кO-Cn B; 2, кO-Cn A; з, $\beta-C n C ; 4, \beta-C n$ A1; $5, \alpha_{s 2^{-}}, \alpha_{s 1^{-}}, \alpha_{s 0^{-}}$Cns.

La surcharge met clairement en évidence les fractions de caséine $\kappa$, mais diminue la résolution entre les caséines $\alpha_{s 2}$ (partie gauche du pic principal), $\alpha_{s 1}$ (pic principal) et $\alpha_{s 0}$ (partie droite du pic principal). it separates them according to their phosphate content. A number of casein samples from herd milks were analyzed on open columns of HA by Barry \& Donnelly (1980). Whole casein was resolved into 5 fractions : $\gamma+$ para- $\kappa-C n s$, $\kappa-\mathrm{Cn}+$ unidentified chymosin-resistant components, unidentified minor protein, $\beta$ $\mathrm{Cn}, \alpha_{\mathrm{s} 1}+\alpha_{\mathrm{s} 2}-\mathrm{Cns}$. The quantitative contribution of chymosin-resistant components to the $\kappa$ - $\mathrm{Cn}$ fraction was deduced from chromatography of chymosin-treated whole casein. The analysis time was $c a$. 10 h. HA-HPLC on a column of Bio-Gel HPHT (Biorad, Richmond, CA) gave quite similar results with a better separation in ca. $45 \mathrm{~min}$. Partial separation of $\kappa A$ and $\kappa$

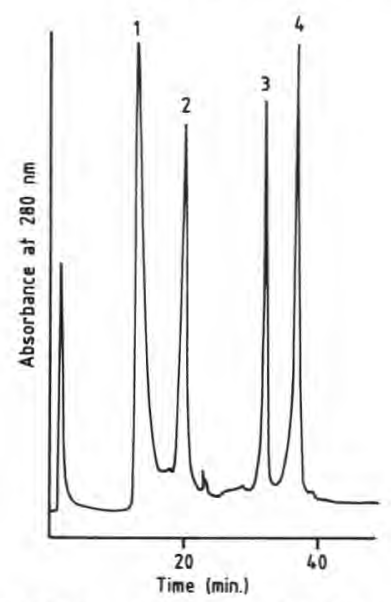

Fig. 11. FLPC separation of acid whey by anion exchange on a Mono $Q$ column (Humphrey \& Newsome, 1984).

Acid whey sample; flow rate : $0.5 \mathrm{ml} / \mathrm{min}$; elution in $0.02 \mathrm{M}$ piperazine buffer $\mathrm{pH} 6.0$ with $0-0.4 \mathrm{M} \mathrm{NaCl}$ gradient. 1 , orotic acid; 2 , $\alpha$-lactalbumin; $3, \beta$-lactoglobulin B; 4 , $\beta$-lactoglobulin A.

Séparation (FPLC) de lactosérum acide par échange d'anions sur une colonne mono $Q$ (Humphrey \& Newsome, 1984).

Echantillon de lactosérum acide; débit : 0,5 $\mathrm{ml} / \mathrm{min}$; élution en tampon pipérazine 0,02 M; $\mathrm{pH} \mathrm{6,O}$ avec un gradient de 0 à $0,4 \mathrm{M}$ en $\mathrm{NaCl}$. 1 , acide orotique; $2, \quad \alpha$-lactalbumine; 3, $\beta$-lactoglobuline $B ; 4, \beta$-lactoglobuline $A$. 
B variants was observed. $\alpha_{\mathrm{s} 2}-\mathrm{Cn}$ was poorly separated from $\alpha_{s 1}-C_{n}$ (tailing part of the $\alpha_{s 1}$-casein peak), but a different elution gradient could produce better separation (Visser et al., 1986; Kawasaki et al., 1986). The main problem appears to be the life-time of HA-HPLC columns.

\section{Chromatofocusing}

To our knowledge, this powerful technique has been employed only for analytical and preparative separations of whey proteins on an open column of Polybuffer Exchanger 94 (Pharmacia, Uppsala, Sweden). With a pH gradient from 5.2 to 4.2 , excellent separation of the main whey proteins was obtained from acid whey (Pearce \& Shanley, 1981, Fig. 12). In our opinion, fast and resolutive separation could be obtained with the Mono P column supplied by Pharmacia.

\section{Hydrophobic interaction and reversed- phase chromatography (HI-, RP-HPLC)}

Although both techniques rely upon hydrophobic interactions between a stationary phase and the solutes to be fractionated, their applications are quite different. With the former, fixation of the solutes on the phase is carried out in aqueous solution at high ionic strength, and elution is achieved by lowering the ionic strength of the mobile phase. In RP-HPLC, fixation occurs in aqueous solution of low ionic strength, and elution is obtained by increasing the hydrophobicity of the mobile phase (increasing the proportion of a low-polarity solvent). In HIchromatography, the stationary phase consists of a polar material to which nonpolar groups (such as phenyl) are covalently attached, while the phases used in RP-HPLC are made of silica with non-polar groups (such as C8 or C18 alkyl chains) similarly attached. Unsubstituted residual silanol groups are subsequently "end-capped" by groups such as trimethylsilyl; in theory, RP-HPLC stationary phases can therefore interact with solutes only by hydrophobic interactions.

Whole casein and whey proteins were each separated by the Chaplin procedure (1986) on a phenyl-Superose HR 5/5 HI column from Pharmacia. With the former, elution was performed with a $0.8-0.05 \mathrm{M}$, $\mathrm{pH} 6.0$, sodium phosphate gradient, containing $3.75 \mathrm{M}$ urea. For whey proteins, in a $1.5-0.05 \mathrm{M}$ gradient of

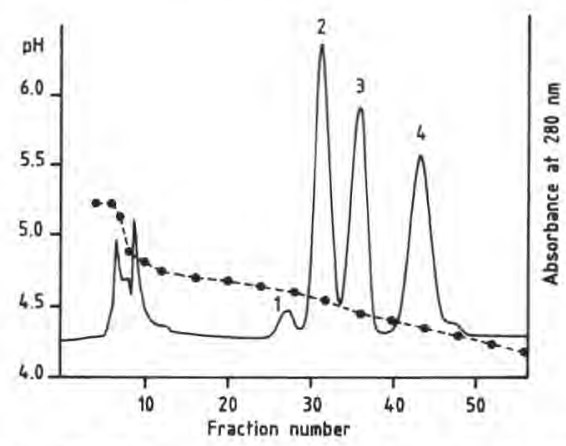

Fig. 12. Chromatofocusing separation of acid whey (Pearce \& Shanley, 1981).

Sample of milk serum concentrated and dialyzed against starting buffer; columns of Polybuffer Exchanger 94 equilibrated in 0.025 $\mathrm{M}$ histidine/ $\mathrm{HCl}$ buffer $\mathrm{pH} 5.2 ; 5 \mathrm{ml}$ of Polybuffer 74 (dil. 1 : 10 in water and adjusted to $\mathrm{pH}$ 4.2) were run on the column before the sample was loaded. Elution with Polybuffer $/ \mathrm{HCl}$. Flow rate : $0.32 \mathrm{ml} / \mathrm{min} .1, B S A$; 2, $\beta$-Lg B; 3, $\beta-\operatorname{Lg} A ; 4, \alpha$-La.

Séparation de lactosérum acide par chromatofocalisation (Pearce \& Shanley, 1981). Echantillon concentré de lactosérum dialysé contre le tampon de départ; colonne de Polybuffer Exchanger 94 équilibrée en tampon histidine 0,025 M-HCl, $\mathrm{pH} 5,2 ; 5 \mathrm{ml}$ de Polybuffer 74 (dil. 1/10 dans l'eau et pH ajusté à 4,2 ) ont été passés sur la colonne avant le dépôt de l'échantillon. Elution avec Polybuffer/HCl. Débit : $0.32 \mathrm{ml} / \mathrm{min}$. 1, BSA; 2, $\beta$ - LgB; 3, $\beta$-LgA; 4, $\alpha$-La. 
ammonium sulfate in $0.05 \mathrm{M}$ sodium phosphate, $\mathrm{pH} 7.0$, was used. Run times were ca. 50 and $30 \mathrm{~min}$, respectively. In our opinion, resulting the poor resolution prevents analytical applications.

A few studies have been made on the behaviour of whole casein (Visser et al., 1986; Carles, 1986) and whey proteins (Pearce, 1983a; Humphrey, 1984) in RPHPLC. For caseins, Visser et al. (1986) compared 2 columns from Biorad

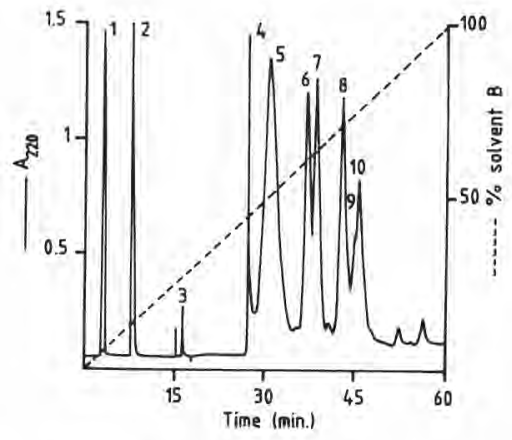

Fig. 13. RP-HPLC separation of individual whole casein on a $\mu$-Bondapak $C 18$ column (Carles, 1986).

Casein sample : $1.25 \mathrm{mg}$ in $50 \mu \mathrm{l}$ of $10 \mathrm{mM} \mathrm{Na}$ phosphate buffer $\mathrm{pH} 7.2,1 \%$ 2-mercaptoethanol, $0.1 \% \mathrm{NaN}_{3}$; flow rate : $1.5 \mathrm{ml} / \mathrm{min}$; solvent A : $10 \mathrm{mM}$ Na phosphate, $10 \mathrm{mM}$ SDS, $\mathrm{pH}$ 7.2; solvent B : 2-propanol/solvent A (2/1; $\mathrm{v} / \mathrm{v}), 10 \mathrm{mM}$ SDS, $\mathrm{pH} 7.2 .1, \mathrm{NaN}_{3}$ and phosphate; 2, mercaptoethanol; 3,4 , no protein; $5, \alpha_{s 1}$-casein; $6,7, \beta$-casein variants (substitution Pro in 6 Leu in 7); $8, \alpha_{\mathrm{s}_{2}}$-casein; $9,10, k$-casein.

Séparation (RP-HPLC) de caséine entière individuelle sur une colonne $\mu$-Bondapak C18 (Carles, 1986).

Echantillon : 1,25 $\mathrm{mg}$ de caséine dans $50 \mu \mathrm{l}$ de tampon phosphate de $\mathrm{Na} 10 \mathrm{mM}, \mathrm{pH} 7,2$, 2-mercaptoéthanol 1\%, $\mathrm{NaN}_{3}$ 0,1\%. Débit : $1,5 \mathrm{ml} / \mathrm{min}$. Solvant $A$ : phosphate de $\mathrm{Na} 10$ $\mathrm{mM}, \mathrm{SDS} 10 \mathrm{mM}, \mathrm{pH} 7,2$; solvant $B$ : 2-propanol/solvant $A(2 / 1 ; v / v), 10 \mathrm{mM} S D S$, $\mathrm{pH} 7,2.1, \mathrm{NaN}_{3}$ et phosphate; 2, mercaptoéthanol; 3, 4, pas de protéines; 5 , caséine $\alpha_{s 1}$; 6,7 , variants de caséine $\beta$ (substitution de Pro dans 6 par leu dans 7); 8 , caséine $\alpha_{s 2} ; 9,10$, caséine $\kappa$.
(Richmond, CA) : a 25 cm RP-318 (C18alkylated, silica-based, $33 \mathrm{~nm}$ pores, $5 \mu \mathrm{m}$ particle size) and a $7.5 \mathrm{~cm}$ TSK-Phenyl RP (phenyl hydroxylated-polyether, 100 $\mathrm{nm}$ pore size, $10 \mu \mathrm{m}$ particle size). Whole casein sample in a pH 7 buffer solution, containing urea and 2-mercaptoethanol, was left standing for $\mathrm{ca} .1 \mathrm{~h}$ and then injected. Solvent A was $0.1 \%$ TFA in $10 \%$ $\mathrm{CH}_{3} \mathrm{CN}$; solvent $\mathrm{B}$ was $0.1 \%$ TFA in $90 \%$ $\mathrm{CH}_{3} \mathrm{CN}$. Elution was achieved by a linear gradient from $A$ to $B$, with recording at $220 \mathrm{~nm}$. The best resolution was obtained with the RP-318 columns, the caseins being eluted in the following order : $\kappa$ ( 3 peaks), $\alpha_{s 2}, \alpha_{s 1}, \beta+\gamma$ (several peaks), in ca. $30 \mathrm{~min}$. Starting from reduced whole casein, Carles (1986) (Fig. 13) obtained a

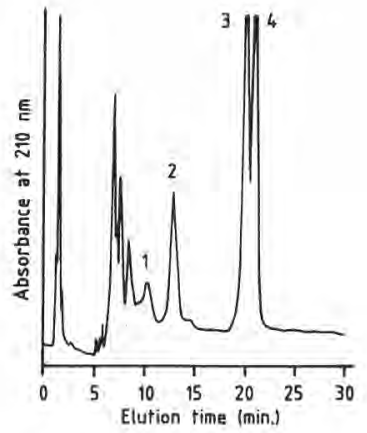

Fig. 14. RP-HPLC separation of defatted cheese whey on Spherisorb C6 column (Pearce, 1983a).

Sample of whole, defatted cheese whey

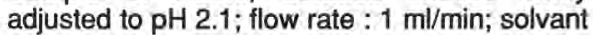
$A: 0.15 \mathrm{M} \mathrm{NaCl} / \mathrm{HCl} \mathrm{pH} 2.1$; solvent $B$ : acetonitrile. Elution by multistage linear gradient from 0 to $48 \%$ B. 1 ; BSA; $2, \alpha-L a ; 3, \beta-\mathrm{LgB} ; 4$, $\beta$-LgA.

Séparation (RP-HPLC) de lactosérum de fromagerie dégraissé sur une colonine Spherisorb C6 (Pearce, 1983a).

Echantillon de lactosérum de fromagerie dégraissé ajusté à $\mathrm{pH} 2,1$. Débit : $1 \mathrm{ml} / \mathrm{min}$. Solvant $A$ : $\mathrm{NaCl} 0,15 \mathrm{M} / \mathrm{HCl}, \mathrm{pH} 2,1$; solvant $B$ : acétonitrile. Elution par gradients linéaires multiples de 0 à $48 \%$ de $B$. 1, BSA; $2, \alpha-L a ; 3$, $\beta \operatorname{Lg} B ; 4, \beta-\operatorname{Lg} A$. 
good resolution on a $30 \mathrm{~cm} \mu$-Bondapak C18 column at $40{ }^{\circ} \mathrm{C}$, with SDS as a counter-ion. The caseins were eluted in the following order : $\alpha_{s 1}, \beta, \alpha_{s 2}, \kappa$. Using this procedure, two genetic variants of $\beta$-casein, differing by a substitution Pro-Leu, were separated and characterized from an individual casein sample.

Figure 14 shows a fractionation of cheese whey on a C6 column (Pearce, 1983a).

\section{Immunological techniques}

Whey proteins behave like any monomeric or oligomeric globular proteins : they are highly antigenic and their determination by usual techniques such as Mancini's double diffusion (1963), rocket-immunoelectrophoresis (Laurell, 1966), enzyme-linked immunosorbent assay (ELISA) (Ruitenberg et al., 1976), and radioimmunoassay (Bennet \& Mohla, 1976 ) is straightforward. Although quite feasible, the determination of the different caseins by immunological techniques is more difficult : these proteins are poor antigens and they occur as aggregates (self aggregation or aggregation with each other).

A few examples of the use of immunological techniques are given below. McLean et al. (1984) used radial immunodiffusion for the determination of $\alpha$-La and $\beta-\mathrm{Lg}$ in a study of the effect of milk protein genetic variants on milk yield and composition. The same technique was extensively used for assaying Igs (antisera against bovine $\lg \mathrm{G} 1$ and $\lg \mathrm{G} 2$ are now commercially available) (e.g., Norman \& Hohenboken, 1981). Ig determination is useful for detecting colostrum in milk. LF was determined in milk by radial immunodiffusion, rocket immuno- electrophoresis (e.g., Welty et al., 1976), and by ELISA in human serum (Hetherington et al., 1983). A radioimmunoassay was developed for $\alpha$-La (Beck \& Tucker, 1977). $\beta-C n$ was quantified in a number of individual human milk samples by rocket immunoelectrophoresis (Chtourou et al., 1985). Using the same technique and specific antisera against the four goat caseins $\left(\alpha_{s 1}, \alpha_{s 2}, \beta, \kappa\right)$, Grosclaude et al. (1987), quite recently, found a Mendelian polymorphism underlying quantitative variations of goat $\alpha_{\mathrm{s} 1}-\mathrm{Cn}$.

Immunological techniques are by far the most specific tools for determining proteins, provided they are used carefully. Their use in dairy technology will probably increase in the near future.

\section{Determination of some indigenous milk enzymes}

For many years, the determination of milk enzymes has been and is still used to assess milk quality (detection of mastitis, heat treatment evaluation). The reader should refer to Kitchen (1985) for a review on milk indigenous enzymes.

As far as the detection of mastitis is concerned, Kitchen found in 1976 that this disease induced an elevated $N$-acetyl- $\beta$ D-glucosaminidase activity in milk. Rapid and simple diagnostic tests have been developed for routine assay in mastitis monitoring programs. As indicated earlier, the level of catalase in milk varies with the somatic cell count, and thus a measure of its activity has been also used to detect mastitis (Kitchen, 1985). This is often performed using a "Catalasemeter". This device measures the time taken for a filter paper disc soaked in the sample and immersed in $\mathrm{H}_{2} \mathrm{O}_{2}$ solution to produce enough oxygen to bring the disc to the 
surface. The catalase activity is inversely proportional to this time (Dubois et al., 1982). However, the indications given by this assay, although correlated to some extent to the hyginic quality of milk (microorganisms also have catalase activities), are often difficult to interpret : indigenous catalase activity is highly dependent upon individuals, breed, feeding and lactation period. Its level is high in colostrum and in late lactation milk.

The efficiency of pasteurization is monitored routinely by the AP test which was discovered in 1933. All milks contain bovine AP. It appears that this enzyme is more heat-resistant than non-spore forming pathogens which can be present in milk. A number of methods for measuring AP activity in milk and dairy products have been published (Richardson, 1985; Seng Kwee, 1985). Most are based on the release by the enzyme of phenol from disodium phenyl phosphate or paranitro phenyl phosphate, or phenolphtalein from phenolphtalein monophosphate. Phenol is measured colorimetrically after reaction with 2,6dichloroquinone chloroimide, which gives Indophenol Blue. Phenolphtalein is detected by $\mathrm{NaOH}$ addition.

These tests must be performed carefully since they can easily give false responses : occurrence of phenol in chemicals and glassware, interfering coloured materials, "reactivation". Milks can give negative phosphatase test results immediately after heating and cooling, or when stored at $4{ }^{\circ} \mathrm{C}$ or below. However, the same milks can give positive test results when not adequately stored, e.g., at or above $10{ }^{\circ} \mathrm{C}$ for extended periods. Such "reactivated" AP can be differentiated from residual AP : storage at $34^{\circ} \mathrm{C}$ in presence of $\mathrm{Mg}$ salts gives 4 to 10 times more AP activity from reactivation than the same product stored without Mg salts (Richardson, 1985).

From the recent work of Griffiths (1986), it appears that LP determination offers the most promising method for detecting heat treatments of the order $76^{\circ} \mathrm{C}$ for $15 \mathrm{~s}$. This enzyme was formerly determined by colorimetric measurement of the reaction products from guiacol or $o$-dianisidine. The best substrate of LP now appears to be ABTS (Boehringer, FRG) which can be used as indicated by Shindler and Bardsley (1975). It was reported that, depending on the temperature of inactivation, some LP activity may be restored after storage. The more severe the heat treatment, the smaller the degree of subsequent regeneration. However, storage at $4{ }^{\circ} \mathrm{C}$ for $24 \mathrm{~h}$ yielded no restoration of activity following heating at $65^{\circ} \mathrm{C}$ to $80^{\circ} \mathrm{C}$ with a holding time of 15 s. LP activity does not vary greatly among raw milk samples (Griffiths, 1986).

As indicated earlier, plasmin activity of milk appears to be beneficial in some dairy products, detrimental in others. This means that a number of dairy manufacturers should be interested in simple tests for assessing the plasmin activity in milk. A rapid, sensitive assay for plasmin in dairy products is available (Richardson, 1983). However both the substrate ( $N$ succinyl-L Ala-L Phe-L Lys-7-amino-4 methyl coumarin), and the required equipment (fluorometer), are expensive. Furthermore, as mentioned previously, milk contains plasmin, $\mathrm{Pg}$ activator, plasmin inhibitors and, likely $\mathrm{Pg}$-activator inhibitor. Thus, the plasmin content is of little significance, since $\mathrm{Pg}$, always present in milk in higher amounts, can give plasmin during milk processing. $\mathrm{Pg}$ determination is quite feasible : plasmin assays are performed before and after $\mathrm{Pg}$ activation by urokinase. But the fate of $\mathrm{Pg}$ and plasmin during processing is 
unknown : $\mathrm{Pg}$ could be converted into plasmin, but $\mathrm{Pg}$ activator and plasmin could also be inactivated.

\section{SOME APPLICATIONS OF MILK PROTEIN ANALYSIS}

A number of such applications have been given throughout this review. We will classify these applications here, and add some that have not been mentioned previously.

\section{Milk protein analysis in dairy products}

\section{Raw milk}

Milk is analyzed routinely in countries where it is paid for, according to its composition and hygienic quality. In this case, protein determination is especially important. In addition, the presence of colostrum, which may cause problems in cheese manufacture, is often sought (detection of lgs by immunological methods). Information on the levels of some enzymes, indicating the occurrence of mastitic milk ( $\mathrm{N}$-acetylglucosaminidase, catalase) or potential proteolytic activity ( $\mathrm{Pg}$, plasmin) is often useful.

A number of individual milks have been, and still are, analyzed to find relationships between genetic variants and technological properties.

\section{Processed fluid milk}

Heat treatments affect both milk microbial flora and whey proteins, caseins being fairly resistant to such treatments. As mentioned above, the extent of inactivation of some milk enzymes can indicate the extent of heat treatments. The effects of UHT and HTST pasteurization of milk on the properties of its proteins have been studied. The solubility of caseins is reduced by UHT treatment. Whey protein nitrogen analysis shows significant protein denaturation. No significant losses in nutritive values were found, and differences in viscosity and emulsification capacity were small (Douglas et al., 1981). It has been suggested that residual plasmin activity (this enzyme is fairly heatresistant) in UHT milk may be one of the factors of late gelation during storage.

\section{Dry milk products}

Protein analyses are extensively used for classification and evaluation of products such as milk powders, non-fat dry milks (NFDM), caseins, caseinates and whey protein concentrates (WPC). In particular, the extent of heat denaturation of whey proteins is often measured. Most methods determine the proportion of soluble whey proteins under various conditions. Whey proteins are considered to be in their native state when they remain soluble after heat treatments. Harland \& Ashworth (1947) developed a turbidimetric method for routine estimation of undenatured whey proteins in heat-treated milk and NFDM. It was standardized by Kuramoto et al. (1959) and modified by Leighton (1962), who introduced the whey protein index (WPI) for NFDM. WPI is defined as milligrams of whey protein nitrogen soluble in saturated $\mathrm{NaCl}$ solution per gram of NFDM. Quantitative analysis by SDS-PAGE was recently compared with these procedures. The described method appears to be effective for obtaining the ratio of casein to whey protein in dairy 
products and detecting adulteration of NFDM (or fluid milk) with WPC (Basch et al., 1985). This type of adulteration can also be detected from amino acid analysis (Greenberg \& Dower, 1986). Von Kneifel and Ulberth (1985) compared methods for the evaluation of heat treatment and residual undenatured whey protein nitrogen content of NFDM, using different procedures to precipitate casein and denatured whey proteins. They found a coefficient of correlation of $0.99(P<0.01)$ between HPLC (gel filtration) and nitrogen analysis of the soluble fraction. Greiner et al. (1985), developed a rapid immunoturbidimetric method for the screening of whey proteins in NFDM and buttermilk, using anti-whole whey serum. The coefficient of variation was ca. $4 \%$ and the minimum detectable level was $3 \%$ whey protein. A higher sensitivity (detection level : less than $1 \%$ whey protein added) was obtained by Olieman \& Van den Beden (1983) by HPLC-gel permeation determination of the CMP, a peptide released from $\kappa$-casein by rennet (see above). However, the latter is more timeconsuming.

\section{Cheese and milk protein hydrolyzates}

As indicated earlier, electrophoresis and electrofocusing are convenient methods for following the extent of proteolysis during cheese manufacture. Furthermore, these methods often allow the identification of the proteinases which have been involved during ripening. In a study of Camembert cheese ripening, Trieu-Cuot \& Gripon (1982) showed from the identification of several degradation products, that rennet, aspartyl- and metallo-proteinases from $P$. caseicolum, and plasmin were involved. A number of milk protein hydrolyzates (from cheese or other sources) are studied in our laboratory. Good information is usually obtained by treating the sample in $2 \%$ TCA and analyzing the insoluble fraction by electrophoresis or ion-exchange FPLC and the soluble fraction by RP-HPLC.

In any case, the degree of proteolysis can be estimated by using TNBS (trinitrobenzene sulfonic acid), a reagent specific for free $\mathrm{NH}_{2}$ groups, and colorimetry (Adler-Nissen, 1979).

Detection of bovine milk in milk (or cheese) from other species

Methods are necessary for detecting fraudulent adulteration of human, goat, sheep and water buffalo milks with bovine milk, which is cheaper. Such methods do exist and are based either on immunological procedures or, more often, on electrophoresis (e.g., Addeo, 1984; Sanchez et al., 1984).

\section{Detection of non-milk proteins in dairy products}

This is usually possible only when the occurrence of a known product is suspected. Detection of soybean proteins in milk products was studied by Hähnel (1984) using SDS-PAGE, IEF and immunodiffusion with antisera to native heatdenatured soya proteins. The highest sensitivity was obtained with the latter.

\section{Milk protein analysis in non-dairy products}

Some food-stuffs (e.g., milk chocolate) contain milk proteins in quantities usually above a certain limit, some contain none (e.g., some meat products). Although 
electrophoresis can be used in some instances, immunological techniques are most interesting in both cases. Their potential applications and limitations have been studied by Willner (1984). It must be realized that the antisera used must be able to recognized denatured (or both native and denatured) milk proteins.

\section{CONCLUSION}

As far as milk protein analysis is concerned, the present status and future trends can be described briefly :

- The whole protein content of milk and many dairy products is widely determined by IR techniques, often with local reference to a dye-binding procedure, and national or international reference to the Kjeldahl method. It seems to us that the Dumas method could supersede the latter when technical problems, due to water content and sample heterogeneity, are solved.

- The content in some protein fractions (e.g., casein in cheese milk, whey protein in WPC) is demanded by many manufacturers. As these fractions cannot be easily distinguished by their physical characteristics, their separation will probably always be required prior to determination by $I R$ or dye-binding methods. Furthermore, NPN assays necessitate nitrogen determination.

- Among the various methods available for the characterization and determination of individual milk proteins, electrophoresis or isoelectric focusing are, no doubt, most suitable for routine analysis of a number of samples. However, more care should be taken when they are used for quantitative measurements. Immunological procedures will certainly be employed more frequently in the near future, when good and inexpensive polyclonal or monoclonal antibody preparations are commercially available.

- Column chromatography does not appear to be suitable, as yet, for analysis of individual milk proteins on a large scale because of their slowness (ca. 30 min per sample). However, automatic equipment capable of working day and night is available. RP-HPLC is the most powerful technique for characterizing peptides and protein hydrolyzates. Quite recent studies show that separation of peptides and proteins by RP- or IE-HPLC can be performed in seconds or minutes, using pellicular, non-porous stationary phases (Kalghatgi \& Horvath, 1987; Kato et al., 1987).

\section{APPENDIX : ABBREVIATIONS AND SYMBOLS USED IN THIS ARTICLE}

\begin{tabular}{|c|c|}
\hline $\mathrm{Ab}$ & Antibody \\
\hline ABTS & $\begin{array}{l}\text { Ammonium 2,2'-azino-di } \\
\text { (3-ethylbenzothiazoline)-6-sulfonate }\end{array}$ \\
\hline $\mathrm{Ag}$ & Antigen \\
\hline AMP & Adenosine monophosphate \\
\hline$A O A C$ & $\begin{array}{l}\text { Association of Official Analytical } \\
\text { Chemists }\end{array}$ \\
\hline AP & Alkaline phosphatase \\
\hline BSA & Bovine serumalbumin \\
\hline CMP & Caseino macropeptide \\
\hline $\mathrm{Cn}$ & Casein \\
\hline DBC & Dye binding capacity \\
\hline ELISA & Enzyme linked immunosorbent assay \\
\hline Gu. $\mathrm{HCl}$ & Guanidinium chloride \\
\hline HP & Horse radish peroxidase \\
\hline HPLC & $\begin{array}{l}\text { High performance liquid } \\
\text { chromatography }\end{array}$ \\
\hline HTST & High sterilization short time \\
\hline IDF & International Dairy Federation \\
\hline IEF & Isoelectric focusing \\
\hline $\lg$ & Immunoglobulin \\
\hline
\end{tabular}




\begin{tabular}{|c|c|}
\hline R & Infra-red \\
\hline ISO & $\begin{array}{l}\text { International Standardization } \\
\text { Organization }\end{array}$ \\
\hline$-\mathrm{La}$ & $\alpha$-Lactalbumin \\
\hline 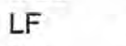 & Lactoferrin (lactotransferrin) \\
\hline$P$ & Lactoperoxidase \\
\hline $\operatorname{Lg}$ & $\beta$-Lactoglobulin \\
\hline - & Wavelength \\
\hline FGM & Milk fat globule membrane \\
\hline IR & Mid-infra-red \\
\hline$M_{r}$ & Relative molecular weight \\
\hline FDM & Non-fat dry milk \\
\hline IR & Near-infra-red \\
\hline PN & $\begin{array}{l}\text { Non-protein nitrogen, or non-protein } \\
\text { nitrogenous substances }\end{array}$ \\
\hline$v$ & $\begin{array}{l}\text { Frequency } v=C / \lambda \text {, with } C=\text { light } \\
\text { velocity, } I / \lambda=\text { wavenumber }\end{array}$ \\
\hline PA & Orthophtaldialdehyde \\
\hline PA & Tissue plasminogen activator \\
\hline AGE & Polyacrylamide gel electrophoresis \\
\hline $\mathrm{Pg}$ & Plasminogen \\
\hline PITC & Phenylisothiocyanate \\
\hline 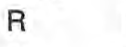 & Reproducibility, or $1 / R$ : reflectance \\
\hline & Coefficient of correlation \\
\hline P-HPLC & Reversed phase HPLC \\
\hline $\mathrm{SD}$ or $\mathrm{S}$ & Standard deviation \\
\hline & Sodium dodecylsulfate \\
\hline TNBS & Trinitrobenzene sulfonic acid \\
\hline & Whey proteins \\
\hline 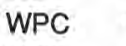 & Whey protein concentrate \\
\hline & Whey protein index \\
\hline
\end{tabular}

\section{REFERENCES}

Addeo F. (1984) Detection and determination of bovine milk in Pecorino cheese. Latte 9, 37-44

Adler-Nissen J. (1979) Determination of the degree of hydrolysis of food protein hydrolyzates by trinitrobenzene sulfonic acid. $J$. Agric. Food Chem. 27, 1256-1262

Alais C., Ribadeau-Dumas B. \& Saint-Lebe L. (1961) Etude de la réaction des protéines du lait avec le Noir Amido. Application au dosage rapide des matières azotées du lait. Lait 41, 241-273
Andrews A.T. \& Cheeseman G.C. (1971) Properties of aseptically packed UHT milk : casein modification during storage and studies with model systems. J. Dairy Res. 38, 193-207

Andrews A.T., Taylor M.D. \& Owen A.J. (1985) Rapid analysis of bovine milk proteins by HPLC. J. Chromatogr. 348, 177-185

Annan W.D. \& Manson W. (1969) A fractionation of the $\alpha_{s}$-casein complex of bovine milk. J. Dairy Res. 36, 259-268

AOAC (1975) Official Methods of Analysis (12th ed.) Association of Official Analytical Chemists, Washington, DC

Aschaffenburg R. \& Drewry J. (1959) New procedure for the routine determination of noncasein proteins of milk. XVth Int. Dairy Congr. London, 3, 1631-1637

Ashworth U.S. \& Chaudry M.A. (1962) Dyebinding capacity of milk proteins for Amido Black $10 B$ and Orange G. J. Dairy Sci. 45, 952957

Baer R.J., Frank J.F. \& Loewenstein M. (1983) Compositional analysis of non-fat dry milk by using near infrared diffuse reflectance spectroscopy. J. Assoc. Off. Anal. Chem. 66, 858-863

Barry J.G. \& Donnelly W.J. (1980) Casein compositional studies. I. The composition of casein from Friesian herd milks. J. Dairy Sci. 47, 71-82

Basch J.J., Douglas F.W., Procino L.G., Holsinger V.H. \& Farrell H.M. (1985) Quantification of casein and whey proteins of processed milks and whey protein concentrates, application of gel electrophoresis and comparison with Harland-Ashworth procedure. J. Dairy Sci. 68, 23-31

Beck N.F.G. \& Tucker H.A. (1977) Relationships between radioimmunoassays of alpha lactalbumin and prolactin in bovine skim milk. J. Dairy Sci. 60, 542-545

Bennet R.M. \& Mohla C. (1976) A solid-phase radioimmunoassay for the measurement of lactoferrin in human plasma : variations with sex, age, and disease. J. Lab. Clin. Med. 88, 156-166

Bidlingmeyer B.A., Cohen S.A. \& Tarvin T.L. (1984) Rapid analysis of amino acids using pre-column derivatization. J. Chromatogr. 336, 93-104

Biggs D.A. (1979) Performance signification for infra-red milk analysis. J. Assoc. Off. Anal. Chem. 62, 1211-1214 
Biggs D.A., Johnsson G. \& Sjaunja L.O. (1987) Analysis of fat, protein, lactose and total solids by infra-red absorption. Bull. IDF 208, 21-30

Böhlen P. \& Schroeder R. (1982) High-sensitivity amino acid analysis : methodology for the determination of amino acid composition with less than 100 picomoles of peptides. Anal. Biochem. 126, 144-152

Bosset J.O., Blanc B. \& Plattner E. (1976) Le dosage des protéines du lait et de ses principaux dérivés : méthodes et appareillages tirés de la littérature parue entre 1964 et 1974. Trav. Chim. Alim. Hyg. 67, 226-261

Brignon G., Chtourou A. \& Ribadeau-Dumas B. (1984) Contamination of human whole casein by whey proteins. Quantitative aspects. Lait 64 , 537-543

Butler J.E. (1974) Immunoglobulins of the mammary secretion. In : Lactation, A Comprehensive Treatise, vol. III (B.L. Larson \& V.R. Smith, eds), Academic Press, New York, pp. 217-255

Carles C. (1986) Fractionation of bovine caseins by reversed-phase high-performance chromatography : identification of a genetic variant. J. Dairy Res. 53, 35-41

Chaplin L.C. (1986) Hydrophobic interaction fast protein liquid chromatography of milk proteins. J. Chromatogr. 363, 329-335

Chtourou A., Brignon G. \& Ribadeau-Dumas B. (1985) Quantificaton of $\beta$-casein in human milk. J. Dairy Res. 52, 239-247

Clarke T. (1979) Standard reconstituted milks for Pro-Milk and Kjeldahl tests. Aust. J. Dairy Technol. 34, 121-123

Cooper J.D.H., Lewis M.T. \& Turnell D.C. (1984) Pre-column O-phtalaldehyde derivatization of amino acids and their separation using reversed-phase high-performance liquid chromatography. J. Chromatogr. 285, 490-494

Creamer L.K. \& Richardson T. (1984) Anomalous behaviour of bovine $\alpha_{s 1}$ - and $\beta$-caseins on gel electrophoresis in sodium dodecyl sulfate buffer. Arch. Biochem. Biophys. 234, 476-486

Dalgleish D.G. (1982) The enzymatic coagulation of milk. In : Developments in Dairy Chemistry. I. Proteins (P.F. Fox, ed.), Applied Science Publishers, London, pp. 157-187

Davies D.T. \& Law A.J.R. (1977a) An improved method for the quantitative fractionation of casein mixtures using ion-exchange chromatography. J. Dairy Res. 44, 213-221
Davies D.T. \& Law A.J.R. (1977b) The composition of whole casein from the milk of Ayreshire cows. J. Dairy Res. 44, 447-454

Davies D.T. \& Law A.R.J. (1980) The content and composition of protein in creamery milks in south-west Scotland. J. Dairy Res. 47, 83-90

De Rham O. \& Andrews A.T. (1986) The roles of native milk proteinase and its zymogen during proteolysis in normal bovine milk. Nestlé Research News 1984/85, Nestec Ltd., 191-194

Dimenna G.P. \& Segall H.J. (1981) Highperformance gel-permeation of bovine skim milk proteins. J. Liq. Chromatogr. 4, 639-649

Dolby R.M. (1961) Dye-binding methods for estimation of protein in milk. J. Dairy Res. 28, 43-55

Douglas F.W., Greenberg R., Farrell H.M. \& Edmonson L.F. (1981) Effect of ultra-high temperature pasteurization on milk proteins. $J$. Agric. Food Chem. 29, 11-15

Driessen F.M. \& Van Der Waals C.B. (1978) Inactivation of native milk proteinase by heat treatment. Neth. Milk Dairy J. 32, 245-254

Dubois G., Charbonneau R. \& Gagnon M. (1982) Dosage automatisé de la catalase dans le lait. Sci. Aliments 2, 245-249

Egli H.R. \& Meyhack U. (1984) Measurements of the principal constituents of solid and liquid milk products by means of near infra-red analyses, In : Challenges to Contemporary Dairy Analytical Techniques. The Royal Society of Chemistry, London, pp. 103-116

Eigel W.N., Butler J.E., Ernstrom C.A., Farrell H.M., Harwalkar V.R., Jenness R. \& Whitney R. $M$ L. (1984) Nomenclature of proteins of cow's milk : fifth revision. J. Dairy Sci. 67, 1599-1631

Eigel W.N., Hofmann C.J., Chibber B.A.K., Tomich J.M., Keenan T.W. \& Mertz E.T. (1979) Plasmin-mediated proteolysis of casein in bovine milk. Proc. Natl. Acad. Sci. USA 76, 2244-2248

Farah Z. (1979) Examination of Aschaffenburg and Drewry procedure for determination of noncasein proteins of milk by discontinuous polyacrylamide electrophoresis. Z. Lebensm. Unters. Forsch. 168, 394-396

Fraenkel-Conrat H. \& Cooper M. (1944) The use of dyes for the determination of acid and basic groups in proteins. J. Biol. Chem. 154, 239-246 
Frank J.F. \& Birth G.S. (1982) Application of near infra-red reflectance spectroscopy to cheese analysis. J. Dairy Sci. 65, 1110-1116

Frankhuizen R. \& Van Der Veen N.G. (1985) Determination of major and minor constituents in milk powder and cheese by near-infra-red reflectance spectroscopy. Neth. Milk Dairy J. 39, 191-207

Gaudillère T. \& Grappin R. (1982) Influence de l'acide citrique sur le dosage des protéines du lait par la méthode infrarouge. Mémoire de fin d'études, SPILAB, Douai

Gehrke C.W., Wall L.L., Absheer J.S., Kaiser F.E. \& Zumwalt R.W. (1985) Sample preparation for chromatography of amino acids : acid hydrolysis of proteins. J. Assoc. Off. Anal. Chem. 68, 811-821

Goulden J.D.S. (1957) Diffuse reflexion spectra of dairy products in the near infra-red region. J. Dairy Res. 24, 242-251

Goulden J.D.S. (1964) Analysis of milk by infrared absorption. J. Dairy Res. 31, 273-284

Grappin R. (1984) Assessment and optimization of indirect instrumental methods for testing major constituents in milk and dairy products. In : Challenges to Contemporary Dairy Analytical Techniques. The Royal Society of Chemistry, London, pp. 77-90

Grappin R. \& Horwitz W. (1988) Determination of nitrogen content in milk by the Kjeldahl method using copper sulfate : interlaboratory study. J. Assoc. Off. Anal. Chem. 71, 893-897

Grappin R. \& Jeunet R. (1976a) Essai de l'appareil Kjel-Foss utilisé pour le dosage d'azote dans le lait. Rev. Lait Fr. 346, 591-597

Grappin R. \& Jeunet R. (1976b) Calibrage des méthodes de dosage de routine des protéines du lait. Rev. Lait Fr. 347, 663-667

Grappin R. \& Jeunet R. (1979) Méthode de routine pour le dosage de la matière grasse et des protéines du lait de chèvre. Lait 59,345 360

Grappin R., Jeunet R. \& Le Doré A. (1979) Determination of the protein content of cows' and goats' milk by dye-binding and infra-red methods. J. Dairy Sci. 62, (suppl. 1) 38

Grappin R., Jeunet R. \& Roguinsky M. (1970) Influence de la mammite sur la composition de la matière azotée des laits de quartiers et sur les dosages de matière azotée par la méthode Noir Amido et l'appareil Infra-Red Milk Analyser. Lait 50, 491-510
Grappin R., Packard V.S., Ginn R.E. \& Mellema J. (1980) Precision of the Pro-Milk method in routine determination of protein in dairy testing laboratories. J. Food Prot. 43, 52-53

Green M.R. \& Pastewka J.V. (1976) Molecular weights of three mouse milk caseins by sodium dodecyl sulfate-polyacrylamide gel electrophoresis and $\mathrm{k}$-like characteristics of a fourth casein. J. Dairy Sci. 59, 1738-1745

Greenberg R. \& Dower H.J. (1986) Detection of added whey protein concentrate in non-fat dry milk by amino acid analysis. J. Agric. Food Chem. 34, 30-32

Greiner S.P., Kellen G.J. \& Carpenter D.E. (1985) A rapid immunoturbidimetric method for whey proteins in non-fat dry milk and buttermilk. J. Food Sci. 50, 1106-1109

Griffiths M.S. (1986) Use of milk enzymes as indices of heat treatment. J. Food Prot. 49, 696-699

Gripon J.C., Desmazeaud M.J., Le Bars D. \& Bergère J.L. (1975) Etude du rôle des microorganismes et des enzymes au cours de la maturation des fromages. II. Influence de la présure commerciale. Lait 548, 502-512

Grosclaude F. (1979) Polymorphism of milk proteins : some biochemical and genetical aspects. Proc. 18th Int. Conf. Anim. Blood Grps 1, 54-92

Grosclaude F. (1988) Le polymorphisme génétique des principales lactoprotéines bovines. INRA Prod. Anim. 1, 5-17

Grosclaude F., Mahé M.F., Brignon G., Di Stasio L. \& Jeunet R. (1987) A Mendelian polymorphism underlying quantitative variations of goat $\alpha_{\mathrm{s} 1}$-caseins. Genet. Sel. Evol. 19, 399412

Guillou H., Miranda G. \& Pelissier J.P. (1987) Analyse quantitative des caséines dans le lait de vache par chromatographie liquide rapide d'échange d'ions (FPLC) Lait 67, 135-148

Guillou H., Pelissier J.P. \& Grappin R. (1986) Méthodes de dosage des protéines du lait de vache. Lait 66, 143-175

Gupta B.B. (1983) Determination of native and denatured milk proteins by high-performance size-exclusion chromatography. J. Chromatogr. 282, 463-475

Hähnel W.C. (1984) The detection of soybean proteins in milk products. Thesis, LudwigMaximilian-Universität, Munich, FRG 
Hamilton T.A., Gornicki S.Z. \& Sussman H.H. (1979) Alkaline phosphatase from human milk. Comparison with isoenzymes from placenta and liver. Biochem. J. 177, 197-201

Harland H.A. \& Ashworth U.S. (1947) A rapid method for estimation of whey proteins as an indication of baking quality of nonfat dry-milk solids. Food Res. 12, 247-251

Hetherington S.V., Spitznagel J.K. \& Quie P.G. (1983) An ELISA for measurement of lactoferrin. J. Immunol. Methods 65, 183-190

Hofmann C.J., Keenan T.W. \& Eigel W.N. (1979) Association of plasminogen with bovine milk fat globule membrane. Int. J. Biochem. 10, 909-917

Huebers H.A. \& Finch C.A. (1987) The physiology of transferrin and transferrin receptors. Physiol. Rev. 67, 520-528

Humphrey R. (1984) Whey Proteins. In : Handbook of HPLC for the Separation of Amino Acids, Peptides, and Proteins, vol. 2, (W.S. Hancock, ed.), CRC Press, Boca Raton, pp. $471-478$

Humphrey R.S. \& Newsome L.J. (1984) High performance ion-exchange chromatography of the major bovine milk proteins. N.Z.J. Dairy Sci. Technol. 19, 197-204

IDF (1986) Provisional standard 20 A. Milk determination of nitrogen content (Kjeldahl method) and calculation of crude protein content, International Dairy Federations, Brussels

IDF (1987) Monograph on rapid indirect methods for measurement of the major components of milk, Bulletin no. 208, International Dairy Federation, Brussels

IDF (1988) International provisional standard 141. Whole milk. Determination of milk fat, protein and lactose content. Guide for the operation of mid-infra-red instruments, International Dairy Federation, Brussels

lto O. \& Akusawa R. (1983) Purification, crystallization and properties of bovine milk catalase. J. Dairy Sci. 66, 967-973

Jenness R. (1982) Interspecies comparison of milk proteins. In : Developments in Dairy Chemistry-1-Proteins (P.F. Fox, ed.), Applied Science Publishers, London, pp. 87-114

Jeunet R. \& Grappin R. (1985) Evaluation de I'Infralyser Dairy pour le dosage des principaux constituants du lait. Tech. Lait 1003, 53-58
Kalghatgi K. \& Horvath C. (1987) Rapid analysis of proteins and peptides by reversedphase chromatography. J. Chromatogr. 398 , 335-339

Kane P.F. (1984) Comparison of $\mathrm{HgO}$ and $\mathrm{CuSO}_{4}$ as digestion catalysts in manual Kjeldahl determination of crude protein in animal feeds : collaborative study. J. Assoc. Off. Anal. Chem. 67, 869-877

Karman A.H. \& Van Boekel M.A.J.S. (1986) Evaluation of the Kjeldahl factor for conversion of the nitrogen content of milk and milk products to protein content. Neth. Milk Dairy J. $40,315-336$

Kato Y., Kitamra T., Mitsui A. \& Hashimoto T. (1987) High performance ion exchange chromatography of proteins on non-porous ion exchangers. J. Chromatogr. 398, 327-334

Kawasaki T., Ikeda K., Takahashi S. \& Kuboki Y. (1986) Further study of hydroxyapatite highperformance liquid chromatography using both proteins and nucleic acids, and a new technique to increase chromatographic efficiency. Eur. J. Biochem. 155, 249-257

Keenan T.W., Dylewski D.P., Woodford T.A. \& Ford R.H. (1983) Origin of milk fat globules and the nature of the milk fat globule membrane. In : Developments in Dairy Chemistry-2-Lipids (P.F. Fox, ed.), Applied Science Publishers, London, pp. 83-118

Kitchen B.J. (1985) Indigenous milk enzymes. In : Developments in Dairy Chemistry-3Lactose and Minor Constituents (P.F. Fox, ed.), Applied Science Publishers, London, pp. 239279

Kjeldahl J. (1883) En ny Methode til Kvaelstofbestemmelse $i$ organiske Stoffer. $Z$. Anal. Chem. 22, 366-382

Kneifel W. \& Ulberth F. (1985) Zur Methodik der Hitzklassifizierung von Magemilchpulver unter Berücksichtigung der HPLC-Analyse. Milchwissenschaft 40, 265-269

Kristoffersen T., Koo K.H. \& Slatter W.L. (1974) Determination of casein by the dye method for estimation of cottage cheese curd yield. Cult. Dairy Prod. J. 9, 12-14

Kühn N.J. (1983) The biosynthesis of lactose. In : Biochemistry of Lactation (T.B. Mepham, ed.), Elsevier, Amsterdam, pp. 159-176

Kuramoto S., Jenness R., Coulter S.T. \& Choi P. (1959) Standardization of the Harland- 
Ashworth test for whey protein nitrogen. $J$. Dairy Sci. 42, 28-38

Lakin A.L. (1970) Methods, apparatus : new product research, process development and design. Chem. Ind. 38, 1227-1229

Lakin A.L. (1974) A rapid method for estimating total protein in milk. Public. Short Communication. IDF Congr. New Delhi, 303-304

Launay D., Devaux M.F., Bertrand D. \& Robert P. (1986) Etude méthodologique de l'analyse du lait par spectroscopie infrarouge et proche infrarouge. Rapport Adrian, Nantes

Laurell C.B. (1966) Quantitative estimation of proteins by electrophoresis in agarose gels containing antibodies. Anal. Biochem. 15, 4552

Leighton F.R. (1962) Determination of whey protein index of skim milk powder. Aust.J. Dairy. Technol. 17, 186-188

Lucas B. \& Sotelo A. (1982) Amino acid determination in pure proteins, foods and feeds using two different acid hydrolysis methods. Anal. Biochem. 123, 349-356

Lunder T.L. (1974) Determination of total nitrogen in foodstuffs according to Dumas, by means of the "Micro Rapid $\mathrm{N}^{\text {" automatic }}$ analyzer. Lab. Pract. 23, 170-172

MacDonald J.L., Krueger M.W. \& Keller J.H. (1985) Oxidation and hydrolysis determination of sulfur amino acids in food and feed ingredients : collaborative study. J. Assoc. Off. Anal. Chem. 68, 826-829

McGann T.C.A. (1978) Automated physicochemical methods for the analysis of milk. A review of major advances (1960-1978) Ir.J. Food Sci. Technol. 2, 141-156

McGann T.C.A., Mathiassen A. \& O'Connell J.A. (1972) Applications of the Pro-Milk MK II. III. Rapid estimation of casein in milk and protein in whey. Lab. Pract. 21, 628-650

McKenzie H.A. (1971) Methods for zone electrophoresis of milk proteins. In : Milk Proteins, vol. II (H.A. McKenzie, ed.) Academic Press, London, pp. 483-508

McKenzie H.A. \& Murphy W.H. (1970) General methods and elemental analysis. Determination of total nitrogen. In : Milk Proteins, vol. I (H.A. McKenzie, ed.), Academic Press, New York, pp. 154-161
McLean D.M., Graham E.R.B. \& McKenzie H.A. (1982) Estimation of casein components by gel electrophoresis. 21st Int. Dairy Congr. Moscow I, 221

McLean D.M., Graham E.R.B. \& Ponzoni R.W. (1984) Effect of milk protein genetic variants on milk yield and composition. J. Dairy Res. 51, 531-546

Mailliart P. \& Ribadeau-Dumas B. (1987) Procédé pour l'obtention de lactoperoxydase active et de lactoferrine à partir de lactosérum et les substances obtenues par ce procédé. French patent 874896

Mancini G., Vaerman J.P., Carbonera A.O. \& Heremans J.F. (1963) A single radial-immunodiffusion method for the immunological quantitation of proteins. Protides Biol. Fluids Proc. $11,370-384$

Manji B., Hill A., Kakuda Y. \& Irvine D.M. (1985) Rapid separation of milk whey proteins by anion exchange chromatography. J. Dairy Sci. $68,3176-3179$

Marshall K.R. (1982) Industrial isolation of milk proteins : whey proteins. In : Developments in Dairy Chemistry-1-Proteins. (P.F. Fox, ed.), Applied Science Publishers, London, pp. 339373

Mercier J.C., Maubois J.L., Poznanski S. \& Ribadeau-Dumas B. (1968) Fractionnement préparatif des caséines de vache et de brebis par chromatographie sur DEAE-cellulose en milieu urée et 2-mercaptoethanol. Bull. Soc. Chim. Biol. 50, 521-530

Metz-Boutigue M.H., Jolles J., Mazurier J., Schoentgen F., Legrand D., Spik G., Montreuil J. \& Jolles P. (1984) Human lactotransferrin : amino acid sequence and structural comparison with other transferrins. Eur. J. Biochem. $145,659-676$

Michalak W. \& Oczkowicz H. (1975) The application of a central system of controlling apparatuses for determining the main milk components and its effects on the comparability of results obtained. Pr. Mater. Zootech. 8, 103-112

Mickelsen R. \& Shukri N.A. (1975) Measuring casein by dye-binding. J. Dairy Sci. 58, 311312

Miranda G. (1983) Etude cinétique de la protéolyse in vivo des lactoprotéines bovines 
dans l'estomac du rat : effet du traitement thermique. Thesis, University of Paris VII

Monsan P.F., Thibault P.A., Brossard C. \& Bruvier C.S. (1985) Procédé d'Extraction des Protéines du Lait, Produits, Appplications du Procédé, et Compositions Pharmaceutiques. French patent FR 2584727

Muller L.L. (1982) Manufacture of casein, caseinates and coprecipitates. In : Developments in Dairy Chemistry-1-Proteins (P.F. Fox, ed.), Applied Science Publishers, London, pp. 315-377

Ng-Kwai-Hang K.F., Hayes J.F., Moxley J.E. \& Monardes H.G. (1984) Association of genetic variants of casein and milk serum proteins with milk fat, and protein production by dairy cattle. J. Dairy Sci. 67, 835-840

Ng-Kwai-Hang K.F., Hayes J.F., Moxley J.E. \& Monardes H.G. (1987) Variation in milk protein concentration associated with genetic polymorphism and environmental factors. J. Dairy Sci. 70, 563-570

Ng-Kwai-Hang K.F. \& Kroeker E.M. (1984) Rapid separation and quantification of major caseins and whey proteins of bovine milk by polyacrylamide gel electrophoresis. J. Dairy Sci. $67,3052-3056$

Nielsen H.K. \& Hurrell R.F. (1985) Tryptophan determination of food proteins by HPLC after alkaline hydrolysis. J. Sci. Food Agric. 36, 893907

Norman L.M. \& Hohenboken W.D. (1981) Genetic differences in concentration of immunoglobulins $\mathrm{G} 1$ and $\mathrm{M}$ in serum and colostrum of cows and in serum of neonatal calves. $J$. Anim. Sci. 53, 1465-1472

Oielman C. \& Van Den Beden J.W. (1983) A sensitive HPLC method of detecting and estimating rennet whey total solids in skim milk powder. Neth. Milk Dairy J. 37, 27-36

Pailler F. (1982) Dosage après minéralisation des protéines par électrode spécifique de l'ion ammonium. Comparaison avec la méthode Kjeldahl. Application aux denrées alimentaires. Ann. Falsif. Expert. Chim. Toxicol. 75, 431-439

Papiz M.Z., Sawyer L., Eliopoulos E.E., North A.C.T., Findlay J.B.C., Sivaprosadaro R., Jones T.A., Newcomer M.E. \& Kraulis P.J. (1986) The structure of $\beta$-lactoglobulin and its similarity to plasma retinol-binding protein. Nature 324, 383-385
Pearce R.S. (1983a) Analysis of whey proteins by high performance liquid chromatography. Aust. J. Dairy Technol. 38, 114-117

Pearce R.J. (1983b) Thermal separation of $\beta$-lactoglobulin and $\alpha$-lactalbumin in bovine cheddar cheese whey. Aust. J. Dairy Technol. $38,144-149$

Pearce R.J. \& Shanley R.M. (1981) Analytical and preparative separation of whey proteins by chromatofocusing. Aust. J. Dairy Technol. 36, 110-114

Peyrouset A. (1982) Process of extraction of lactoferrin and immunoglobulins of milk. Société Nationale Elf-Aquitaine. UK patent application, GB 2098 998A

Pfeil W. (1987) is thermally denatured protein unfolded? The example of $\alpha$-lactalbumin. Biochim. Biophys. Acta 911, 114-116

Pierre A. \& Fauquant J. (1986) Principe pour un procédé industriel de fractionnement des protéines du lactosérum. Lait 66, 405-419

Prieels J.P. \& Peiffer R. (1985) Procédé de purification des protéines du lait et de ses dérivés. French patent FR 2576752

Pruitt K.M. \& Tenovuo J.O.(1985) The Lactoperoxidase System : Chemistry and Biological Significance M. Dekker Inc., New York

Quan F., Korneluk R.G., Tropak M.B. \& Gravel R.A. (1986) Isolation and characterization of the human catalase gene. Nucleic Acids Res. 14, 5321-5333

Reimerdes E.H. (1982) Changes in the proteins of raw milk during storage. In : Developments in Dairy Chemistry-1-Proteins (P.F. Fox, ed.), Applied Science Publishers, London, pp. 271288

Rexroad P.R. \& Cathey R.D. (1976) Pollutionreduced Kjeldahl method for crude protein. $J$. Assoc. Off. Anal. Chem. 59, 1213-1217

Reynolds J.A. \& Tanford C. (1970) The gross conformation of protein-sodium dodecyl sulfate complexes. J. Biol. Chem. 245, 5161-5165

Richardson B.C. (1983) Variation of the concentration of plasmin and plasminogen in bovine milk. N.Z.J. Dairy Sci. Technol. 18, 247252

Richardson G.H. (1985) Standard Methods for the Examination of Dairy Products. 15th ed., American Public Health Association, Washigton DC 
Robert P., Bertrand D., Devaux M.F. \& Grappin R. (1987) Multivariate analysis applied to nearinfra-red spectra of milk. Anal. Chem. 59, 2187 2191

Rodbard D., Kapadia G. \& Chrambach A. (1971) Pore gradient electrophoresis. Anal. Biochem. 40, 135-157

Roeper J. \& Dolby R.M. (1971) Estimation of the protein content of wheys by the Amido Black method. N.Z.J. Dairy Sci. Technol. 6, 6568

Rowland S.J. (1988) The determination of the nitrogen distribution in milk. J. Dairy Res. 9, 4246

Ruitenberg E.J., Steerenberg P.A., Brosi B.J.M. \& Buys J. (1976) Reliability of the enzyme linked immunosorbent assay (ELISA) for the serodiagnosis of Trichinella spirales infections in conventionally raised pigs. J. Immunol. Methods 10, 67-83

Sanchez Ramos M. \& Olano A. (1984) Quantification of cow's milk in goat's milk by polyacrylamide-gel electrophoresis using $\alpha_{\mathrm{s} 1}$ casein as internal standard. J. Dairy Sci.67, (suppl. 1) 72

Sarwar G., Christensen D.A., Finlayson A.J., Friedman M., Hackler L.R., MacKenzie S.L., Pellett P.L. \& Tkachuk R. (1983) Inter- and intra-laboratory variation in amino acid analysis of food proteins. J. Food Sci. 48, 526-531

Sato H., Seino T., Kobayashi T., Murai A. \& Yugari Y. (1984) Determination of the tryptophan content of feed and feedstuffs by ion exchange liquid chromatography. Agric. Biol. Chem. 48, 2961-2969

Schaller J., Moser P.W., Dannegger-Muller G.A.K., Rosselet S.J., Kampfer U. \& Rickli E.E. (1985) Complete amino acid sequence of bovine plasminogen. Comparison with human plasminogen. Eur. J. Biochem. 149, 267-278

Schmidt D.G. (1982) Association of casein and casein micelle structure. In : Developments in Dairy Chemistry-1-Proteins (P.F. Fox, ed.), Applied Science Publishers, London, pp. 61-86

Schober R. \& Hetzel H.F. (1956) Uber ein einfache, kolorimetrische Bestimmung von Milchproteinen. Milchwissenschaft 11, 123-126

Seibert B., Erhardt G. \& Senft B. (1985) Procedure for simultaneous phenotyping of genetic variants in cow's milk by using isoelectric focusing. Anim. Blood Groups Biochem. Genet. 16, 183-191
Seng Kwee W. (1985) An improved Aschaffenburg and Mullen alkaline phosphatase test for coloured milk products. Aust. J. Dairy Technol. 40, 27-30

Shapiro A.L., Vinuela E. \& Maizel J.V. (1967) Molecular weight estimation of polypeptide chains by electrophoresis in SDS-polyacrylamide gels. Biochem. Biophys. Res. Commun. 28, 815-820

Sherbon J.W. (1975) Collaborative study of the Pro-Milk method for the determination of protein in milk. J. Assoc. Off. Anal. Chem. 58, 770-776

Sherbon J.W. (1978) Recent developments in determining protein content of dairy products by dye-binding. J. Dairy Sci. 61, 1274-1278

Sherbon J.W. \& Luke H.A. (1968) Collaborative study of the dye-binding method applied to chocolate milk drinks, cultured buttermilk and half-and-half. J. Assoc. Off. Anal. Chem. 51, 811-816

Sherbon J.W. \& Luke H.A. (1969) Comparison of the dye-binding and Kjeldahl methods for protein analysis of non-fat dry milk and ice cream. J. Assoc. Off. Anal. Chem. 52, 138-142

Shimazaki K. \& Sukegawa K. (1982) Chromatographic profiles of bovine milk whey components by gel filtration. J. Dairy Sci. 65 , 2055-2062

Shindler J.S. \& Bardsley W.G. (1975) Steadystate kinetics of lactoperoxidase with $A B T s$ as chromogen. Biochem. Biophys. Res. Commun. 67, 1307-1312

Sjaunja L.O. (1982) Studies on milk analyses of individual cow milk samples. Report 56, Swedish University of Agricultural Sciences, Uppsala

Sjaunja L.O. \& Andersson I. (1985) Laboratory experiments with a new IR milk analyzer, the Milko-Scan. Acta Agric. Scand. 85, 345-352

Spies J.R. \& Chambers D.C. (1948) Chemical determination of tryptophan. Anal. Chem. 20, 30-39

Steinsholt A.K. (1976) Reasons for reduced binding capacity of Amido Black 10 B in milk products, Report 193, Dairy Research Institute, Agricultural University of Norway

Stuart D.I., Acharya K.R., Walker N.P.C., Smith S.G., Lewis M. \& Phillips D.C. (1986) $\alpha$ lactalbumin possesses a novel calcium-binding loop. Nature 324, 84-87 
Swaisgood H.E. (1982) Chemistry of milk protein. In : Developments in Dairy Chemistry1-Proteins (P.F. Fox, ed.), Applied Science Publishers, London, pp. 1-59

Tarassuk N.P., Abe N. \& Moats W.A. (1967) The dye-binding of milk proteins. Tech. Bull. US Dep. Agric. 1369, Washington, DC

Trieu-Cuot P. (1981) Etude des caséines et de leurs produits de dégradation par méthodes électrophorétiques. Application à l'étude de l'affinage du camembert. Thesis, University of Paris VII

Trieu-Cuot P. \& Gripon J.C. (1981) Electrofocusing and two-dimensional electrophoresis of bovine caseins. J. Dairy Res. 48, 303-310

Trieu-Cuot P. \& Gripon J.C. (1982) A study of proteolysis during Camembert cheese ripening using isoelectric focusing and two-dimensional electrophoresis. J. Dairy Res. 49, 501-510

Udy D.C. (1956) A rapid method for estimating total protein in milk. Nature 178, 314-315

Van Boekel M.A.J.S. \& Ribadeau-Dumas B. (1987) Addendum to the evaluation of the Kjeldahl factor for conversion of the nitrogen content of milk and milk products to protein content. Neth. Milk Dairy J. 41, 281-284

Van Reusel A. \& Klijn C.J. (1987) Automated methods for routine analysis of raw milk. The dye-binding method for determination of the protein content of milk. Bull. IDF 208, 17-20

Vendrel J. \& Aviles F. (1986) Complete amino acid analysis of proteins by dansyl derivatization and reversed-phase liquid chromatography. J. Chromatogr. 358, 401-413
Visser S., Slangen K.J. \& Rollema H.S. (1986) High performance liquid chromatography of bovine caseins with the application of various stationary phases. Milchwissenshaft 41, 559562

Waite R. \& Smith G.M. (1972) Measurement of the protein content of milk from mastitic quarters by the Amido Black method. J. Dairy Res. 39, 195-201

Weiss M.J., Henthorn P.S., Lafferty M.A., Slaughter C., Raducha M. \& Harris H. (1986) Isolation and characterization of a cDNA encoding a human liver/bone/kidney-type alkaline phosphatase. Proc. Natt. Acad. Sci. USA $83,7182-7186$

Welty F.K., Smith K.L. \& Schanbacher F.L. (1976) Lactoferrin concentration during involution of the bovine mammary gland. J. Dairy Sci. 59, 224-231

Wilkinson J.M. (1978) The separation of dansyl amino acids by reversed-phase high performance liquid chromatography. J. Chromatogr. Sci. 16, 547-552

Willner I. (1984) Potential applications and limitations of immunological determination of milk proteins in foods and animal feeds. Thesis, Technishe Universität, München, FRG

Yaguchi M. \& Rose D. (1971) Chromatographic separation of milk proteins : a review. J. Dairy Sci. $54,1725-1743$

Yaguchi M. \& Tarassuk N.P. (1967) Gel filtration of acid casein and skimmilk on Sephadex. J. Dairy Sci. 50, 1985-1988 